Florida International University

FIU Digital Commons

\title{
A study to analyze the economic and the social impact of the growth of international tourism on Aruba and its future role in the Aruban society
}

Ruben F. Giel

Florida International University

Follow this and additional works at: https://digitalcommons.fiu.edu/etd

Part of the Hospitality Administration and Management Commons, and the Tourism and Travel Commons

\section{Recommended Citation}

Giel, Ruben F., "A study to analyze the economic and the social impact of the growth of international tourism on Aruba and its future role in the Aruban society" (1979). FIU Electronic Theses and Dissertations. 3934.

https://digitalcommons.fiu.edu/etd/3934

This work is brought to you for free and open access by the University Graduate School at FIU Digital Commons. It has been accepted for inclusion in FIU Electronic Theses and Dissertations by an authorized administrator of FIU Digital Commons. For more information, please contact dcc@fiu.edu. 
A STUDY TO ANALYZE THE ECONOMIC AND THE SOCIAL IMPACT OF THE GROWTH OF INTERNATIONAL TOURISM ON ARUBA AND ITS FUTURE ROLE IN THE ARUBAN SOCIETY by Ruben F. Giel

A thesis presented to the Faculty of Hospitality Management Florida International University for the Degree of NAGTER OF SCIENCE

$$
\text { June } 1979
$$


THE QUALIFICATION OF THE RESEARCHER

Ruben F. Giel was born in Aruba Netherlands Antilles in 1947, finished High School there.

In 1967 he received a scholarship from the Island Government of Aruba to go to Holland to study in the field of Hotel and Restaurant business at the St. Joseph Horeca Dag School The Hague. After four years, he received his diploma and returned to Aruba where he worked as a Food and Beverage Controller at the Holiday Inn Aruba for two years. In 1975, he was employed by the Government of Aruba as a Food and Beverage Instructor, which position he still holds to date. During the years employed by the Aruban Government, he worked with I.L.O (International Labor Organization) experts to enhance his instructoral knowledge.

In March 1976, Ruben F. Giel was awarded a scholarship by the Aruban Government to further his studies in Hotel and Restaurant Management at Florida International University. He received a Bachelor of Science degree in Hotel and Restaurant Management from the Florida International University in December 1976. The scholarship was extended in March 1977 to enable him to do post graduate work with the objective of obtaining a Masters of Science degree. 


\section{ACKNOWLEDGENENTS}

The writer wishes to express his appreciation for the guidance given by Dr. Norman Ringstrom and Mr. Richard Huse in the preparation of this thesis. The writer also wishes to thank all the people who have assisted in making this thesis possible, through release of pertinent information.

A special gratitude is going to Dr. Gerald Lattin, Dean of the Hospitality Management at F.I.U. who made it possible for the author to embark upon his studies at Florida International University. 
DEDICATED TO MY NIFE

\section{ELAINE}


TABLE OF CONTENTS

Chapter

Page

INTRODUCTION

I. A. Statement of Problem. . . . . . . . . . . 2

B. The Importance of the Study . . . . . . . 4

C. The Delimitations. . . . . . . . . . 8

D. Assumptions. • . . . . • . . . . . . 8

E. The Definition of Terms. . . . . . . . . 9

I. THE REVIEW OF THE RELATED LITERATURE • • • • • • 11

A. Historical Overview. . . . . . . . . . 11

B. The Economic Impact. . . . . . . . . 13

C. The Social Impact. . . . . . . . . . 16

D. The International Tourism Growth . . . . 18

E. Summary. • • • . • . • . • • . . . 20

III. TOURISM HISTORY AND ORIGINS OF TOURISM IN

ARUBA. . . . . . . . . . . . . . 22

A. The Origins of Tourism in Aruba. . . . . . 23

IV. THE ECONOMIC IMPACT. . . . . . . . . . . . . 30

A. The Importance of the International

Tourism Growth . . . . . . . . . • 32

B. The Hotel Sector . . . . . . . . 62

C. Economic Constraints . . . . . . . . 88

V. THE SOCIAL IMPACT. • . . • . . . . . . . . . 90

A. Implications of Impact . . . . . . . . 94 
Table of Contents (continued)

Chapter

Page

VI THE FUTURE ROLE OF TOURISM. . . . . . . . . 99

VII SUMMARY AND CONCLUSIONS. . . . . . . . . 107

APPENDIX A. Map of Aruba. . . . . . . . . . 111

APPENDIX B. Summer-Fall Hotel Rates

April 16, 1978-December 15, 1978. . . 112

BIBLIOGRAPHY . . . . . . . . . . . . . . 113

A. Books.................. 113

B. Research Reports and Unpublished Papers. . . 114 


\section{LIST OF TABLES}

Table

Page

3.1 Guests by Country of Residence

3.2 U.S. Visitors by Region and

state of origin

4.1 - 4.20 Recapitulation Statistical Data on Non-Resident Visitors 1958 - 1977.

4.21

Working Labor Force 1974 and 1978

$4.21 \mathrm{~A}$

Contribution of Tourism to the Aruban Economy 1973-1976

4.22 Development of Hotel Accomodation Number of Rooms per Type of Accomodation

4.23

Length of Stay by Type of Guest

December 1, 1977 to May 31, 1978

4. 24

Length of Stay by Month

December 1, 1977 to May 31, 1978

4.25

Number of Adults by Type of Guest December 1, 1977 to May 31, 1978

4.26

Number of Adults by Month

December 1, 1977 to May 31, 1978

Number of Children by Type of Guest

December 1, 1977 to May 31, 1978

4.28 Number of Children by Month

December 1, 1977 to May 31, 1978

4. 29

Room Rate Paid by Type of Guest

December 1, 1977 to May 31, 1978

4.30

Room Rate Paid by Month

December 1, 1977 to May 31, 1978 
List of Tables (continued)

Table

4.31

Stay Plan by Type of Guest

December 1, 1977 to May 31, 1978

4.32

Stay Plan by Month

December 1, 1977 to May 31, 1978

5.1

Justice and Prisions Records

1967-1977

97

5.2

Registered Divorces on Aruba

1967-1977

98 


\section{APPENDICIES}

Appendix

A

Map of Aruba

B

Summer-Fall Hotel Rates.

April 16, 1978 - December 15, 1978

Page

111

112 


\section{INTRODUCPION}

Aruba is a delightful island. Its bleached white beaches and its climate, as perfect as a climate can be, have for the last twenty years fascinated the foreign tourist.

Many foreign tourists who visited Aruba have decided they wanted to build a vacation or retirement home there. Many others who heard or read about Aruba also became interested in the possibility of acquiring an island hiçeaway.

Whether it is wanderlust, the white beaches, the perfect climate or merely the desire for fun and relaxation that brings the tourists to Aruba, he is never disappointed. Through the last year Aruba was involved in the mass movement of the foreign tourist: Aruba always has maintained its tranquility and hospitality for the foreign travelers. 


\section{CHAPTER I}

\section{A. Statement of the Problem}

The purpose of this study is to analyze the economic and the social impact of the growth of International Tourism on Aruba and to determine its future role in the Aruban society.

International tourism has experienced phenomenal growth during the past twenty years in Aruba. Its growth has been especially rapid since the early sixties. This study is concerned with the economic and social development of International Tourism in Aruba during the last 20 years. It addresses itself primarily to the question of the contribution of the International Tourism sector to the social economy and its future role in the Aruban society.

The study will be limited to Aruba. The study will not attempt to predict the rates of foreign exchange and will not predict any political change that may occur in Aruba in the future.

Chapter II of the study is research of the related literature which includes; A Historical Overview; The Economic Impact; The Social Imapct and the International Tourism growth. 
Chapter III will reveal both the history and tourism history of Aruba. It also analyzes the origins of the International Tourism by country and a detailed analysis has been provided by state, since a major source of guest registrants come from the United States. In addition, a percentage to total will be given.

Chapter IV analyzes the economic impact of International Tourism on Aruba. Relevant data of the years 1959 through 1977 will be analyzed based on the contribution to the deviation of the economy. External influences, such as Foreign Aid, will be eliminated to preserve the basis of the analysis on the impact of International Tourism in Aruba. This section will also give the growth of International Tourism Industry; in what manner and at what time the economic impact of International Tourism started to contribute to Aruban economy. Tourist receipts and average spending per tourist will be determined.

Contribution of the International Tourism Industry to the Aruban G.N.P. will be analyzed.

Specific trends in the industry will be analyzed, such as:

- countries of origin of visitors

- seasonal pattern of arrival

- mode of arrival

- length of stay

- type of accommodation preferred 
- spending per tourist

- supply of accommadation

- occupancy levels of local accommodations by type

- accommodation rates.

The trends will be summerized from tables and graphs gathered on the above topics to indicate the economic impact of the growth of International Tourism.

Chapter $\mathrm{V}$ analyses the social impact of the growth of the International Tourism Industry. Employment figures and levels will be stated. The responses by social leaders obtained through interviews will be analyzed to ascertain changes in the morals of the society.

Chapter VI will give the prospect of tourism in Aruba and Chapter VII will summarize and conclude the study.

B. The Importance of the Study

The official opening of Aruba's first multi-story resort hotel in 1959, heralded a period of rapid growth for tourism on Aruba. The nature of this growth has caused such an impact on the island's economy, and more importantly on the island's people, that it would be desirable to reflect for a moment on the history of Aruba and its people up to that memorable day in 1959.

Discovered by Alonso de Ojeda on one of his voyages to the West about the year 1499, Aruba, except for a place on the map, remained insignificant up to the latter part 
of the 19th century. An attempt at gold mining and milling by the English at that time met with limited success and stirred the scant population into an era of industrialization and away from the basic efforts at agriculture and fishing. The taste of mechanical industry, a novelty at the time, lingered on long after the mines had closed and the wheels of the gold mills lay idle for lack of spare parts because of the devastation of World War I.

Accustomed as they were to a new type of industry and a paycheck, the male population left Aruba to seek gainful employment elsewhere, Venezuela's newly discovered oilfields, Colombia's stable agricultural society, Cuba's growing sugar industry, and Panama's joining of the oceans all beckoned with abundant employment opportunities and regular paychecks.

The only significant agricultural activity on Aruba, the aloe culture, suffered by the exodus of the able-bodied population and was never able to recover its prominent position.

Activity on Aruba practically remained at a standstill until 1925, when the leeward coastline with its possibilities for deep-sea harbors, attracted the attention of American investors looking for a place to transfer the abundant black gold that was flowing from Lake Maracaibo oilfields from lake tankers to ocean-going tankers. The petroleum harbor which was eventually built and the influx of thousands of workers from all parts of the world, shot 
Aruba and its people into the era of the oil industry, leaving an indelible mark on the culture of the people, and needless to say, on the economy of Aruba. In less than ten years, Aruba's population soared from 12,000 to 35,000. In the meantime, the transfer harbor had been expanded and the oil refinery was built where previously wild goats roamed in search of grazing grounds. Even today, remnants of that boom era, in the form of hastilybuilt shanty houses, can be seen close to the 10-foot high fence which surrounds the refinery. World War II precipitated a second boom which lasted until 1951, when automation finally caught up with the oil industry and the refinery started a reconstruction phase that would reduce the labor force by thousands and would fill the ranks of the unemployed. Also, in 1951, a significant event changed the manner in which Aruba was governed and the Colonial period came to an end as Aruba was set adrift to seek its own fortunes with self-government.

Luckily for Aruba, the jet age was making its entrance in the world of travel and the prospect of shorter flying times and more direct routes formed the basis for a few men of foresight to analyze the possibility of launching Aruba into the tourist trade. What these men saw, and what they did, made Aruba the hottest discovery in the Caribbean, a reputation that it still enjoys to this date.

As early as 1947, attempts were made to interest 
Dutch cpaital to invest in the tourist trade. However, the adament attitude of the then colonial government precluded the addition of casino's to hotels, and not even the beautiful beaches and the year round balmy weather were considered to be sufficient to attract visitors from Latin and North America. In 1956, attitudes had changed, the government had changed, and out of a desperation to alleviate the unemployment situation, construction was started on the first resort hotel with local and Venezuelan capital.

The entrepreneurs must have been aware of the economic impact that the tourist trade would have on Aruba. However, except for a mild warning from the Roman Catholic Church, which is the predominant religion on the island, no study was made of the possible effects of this trade on the people.

As a matter of fact, even the economic impact, which certainly helped the unemployment situation, has never been researched thoroughly.

The continued economic and social development of Aruba is expected to benefit from this research as there have been no similar studies.

It is true that the economic and social environments of certain islands in the Caribbean have been devastated by the unplanned and on-the-spur development of the International Tourism Industry. However, this study attempts to form a basis for future government policies to encourage 
International Tourism to Aruba and to secure a planned economic growth. This will help to guarantee the people of Aruba a standard of living that they have become accustomed to.

The study will indicate problems that the future growth in International Tourism may bring to Aruba as this extremely vulnerable industry has at present no effective plan in which the Aruban government, commerce and the people of Aruba in general have a strong participation.

In general, the study will propose positive ways that the International Tourism Industry can benefit Aruba in both its economic and social environments and to which purpose this study is dedicated.

\section{The Delimitations}

The study will be limited to Aruba.

The study will not attempt to predict in the rates of foreign exchange.

The study will not attempt to predict any political change that may occur in Aruba in the future.

D. Assumptions

The first assumption. The first assumption is that 
International tourists will continue to come to Aruba in the future.

The second assumption. The second assumption is that International Tourism can provide employment for the growing labor force of Aruba.

The third assumption. The third assumption is that there is data available on both economic and social aspects to do this study.

E. The Definition of Terms

Aruba. An island in the Caribbean Sea which lies 15 miles off the Venezuelan coast.

Economic Impact. A deviation in the structure of International balance of payments and trade flow among other factors in the economy, the result of which has a changing effect on the economy of the island.

Social Impact. A deviation in the structure, function, and relationship of social systems caused by external influences exerted on the system.

International Tourism. In 1937, the committee of Statistical Experts of the League of Nations recommended the first definition of the term "foreign tourist" which gained some international acceptance and which remains in essence to this day: "Any person visiting a country, other than that in which he/she usually resides, for a period of at least twenty-four hours." 
Aruban Economy. The main sources of income of Aruba are: The oil industry, tourism and commerce. Banking and trade expanded in connection with both the oil industry and the International Tourism Industry. 
CHAPTER II

THE REVIEW OF THE RELATED IITERATURE

\section{A. Historical Overview}

The tourist industry of Aruba is very young. In

order to understand the development of its tourism it is essential to go back to its early history, beginning approximately in the year 1500:

- . Aruba. . was discovered about 1500 by Alonso de Ojeda when it was still in a stone age. From excavations it is known that Aruba was inhabited before that date. In order to form a picture of how conditions were on Aruba before 1500 recourse must be had to the results of excavations here and elsewhere. It is the period of Aruba's prehistory. Considering its poverty in natural resources the island is likely to have been no more than a halting place for a succession of Indians, tribes and clans. This must have been so both before the discovery and after; the Indians came and went. 1

In the course of the centuries preceding its discovery people are thought to have lived everywhere on the island. Based upon objects, fragments of pots and remainder of shells that were found, the history of Aruba can be divided into three periods:

IJohan Hartog, Aruba, Past and Present (Oranjestad, Aruba: J.D. deWitt, 1961), p. 1. 
"1. the time before the discovery, a period about which little information exists;

"2. the Spanish period, from about 1500-1636;

"3. the Dutch period, which commences with the arrival of the Dutch in 1636 and ends with the death of the last Indian in or about $1862 . " 2$

Paleolithic evidence is that given the right environment man prefers to reamin one place and not wander over the face of the earth. During a million years only changes of climate, dwindling food supplies or hostile invaders could drive human beings from their safe retreat. 3

In 1937, the Committee of Statistical Experts of the League of Nations recommended the first definition of the term 'foreign tourist', which gained some international acceptance and which remains in essence to this day:

- . Any person visiting a country, other than that in which he usually resides, for a period of at least twenty four hours.

- . The following were to be considered tourists within this definition:

a. persons traveling for pleasure, for domestic reasons for health etc.

b. persons traveling to meetings, or in a representative capacity of any kind (scientific, administrative, diplomatic, religious, athletic, etc.).

c. persons traveling for business reasons.

d. persons arriving in the course of a sea cruise, even when they stay less than 24 hours. (The latter should be reckoned as a separate group, disregarding if necessary their usual place of
residence.)

2Ibid., pp. 5-6.

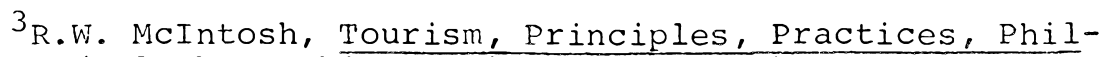
osophies (Columbus, Ohio: Grid, Inc., 1972), p. 13.

${ }^{4}$ A.J. Buckart, S. Medlik, Tourist Past, Present and Future (London: Heinemann, 1974), p. 91. 
Until 1959, few visitor records were kept except for those happenings that were considered as occurring for the first time in the history of Aruba.

- During the Spanish period (1500 - 1676), the island had been regarded as an 'isla inutil' (useless island) and as a consequence been neglected. English and Dutch ships were sighted near but they actually did not set foot ashore. Even the Spanish rulers of these islands did not visit Aruba.

It was peter stuyvesant, according to the Dutch records kept, who was the first visitor of Aruba in December 1742. Actually, he visited the island and took horses aboard so as to have some cavalry with which to act on his raids on the mainland of Venezuela.

The oil industry brought the first cluster of visits to the island between 1924 and 1928 where there are about 200 recorded schooners, yachts, motor-vessels, tankers, and other vessels arrivals bringing American business-men and visitors for the installation of the oil refinery. 5

The first tourist ship to call at the harbour was on

the 3rd of February 1955, (Tradewind) which opened the new era in the history of the island.

- Tourism dates from the beginning of 1955 after the visit of the 'Tradewind'. The 'Grace Line', whose freighters only used to call at our island before June 1956, ever since have had their luxury liners head for Aruba. During the cruisingseason the biggest tourist vessels now moor in our harbour. 6

B. The Economic Impact

Krause, Jud and Joseph cited in their study that:

- . International tourism has been growing in volume during recent decades, both for developed

5Hartog, Aruba, Past and Present, p. 435.

${ }^{6}$ Ibid. , 
regions and for 'developing' regions. In developing regions, in fact, international tourist business has been growing faster than other industry. An 11 percent annual increase, overall, in tourist receipts over the past two decades, in comparison with, for example, a receipts increase in commodity exportation averaging only 4 percent annually. The number of visitors to developing courtries (considered here as areas other than Europe and North America) increased from $2.2 \mathrm{million}$ in 1950 to $11.2 \mathrm{million}$ in 1967, with associated receipts rising from $\$ 0.5$ billion to $\$ 3$ billion. Concurrently, total exports of all developing çountries increased from $\$ 19.1$ billion
to $\$ 40$ billion.

The construction of the Aruba Caribbean Hotel was begun by the island administration as soon as they finally resolved to attract tourists so as to make our island benefit by the yearly increasing wave of vactioners in the Caribbean area. In this manner, it was hoped, a considerable source of income would be opened up. Again quoting from Frause, Jud and Joseph:

- In an examination of the general role of International Tourism in a program of economic development, tourist business can be considered a fact of the foreign sector. So regarded, international tourist business offers two distinct advantages that, for locales such as Latin America and the Caribbean, set it apart from traditional regional exports. First, tourism provides a potentially expanding outlet for labor, a relatively abundant local resource. Second, tourist business provides a potentially increasing source of foreign exchange, a relatively scarce resource much needed for continued development. 8

7 Walter Krause and G. Donald Jud with Hyman Joseph. International Tourism and Latin American Development (Austin: Bureau of Business Research, University of Texas, 1973), pp. 3-4.

${ }^{8}$ Ibid., p. 10. 
The following table illustrates the relative growth of tourism in Aruba from 1959 to 1977.9

$\begin{array}{lllll}\text { Visitors } & \text { Percent } & \text { Cruise } & \text { Percent } \\ \text { Year } & \text { By Air } & \text { Change } & \text { Tourists } & \text { Change }\end{array}$

1959

1965

1970

1975

1976

1977

By Air

Change

Tourists

Change

From the above table it can be seen that the number of visitors increased almost 20 times in 19 years of successful tourist business. The significant increase was due to the fact that the island administration was actively engaged in the promotion of tourism, not only abroad but also locally, and the American operated hotels who did their own promotions from which no advertising dollar was obtained.

According to Hartog:

- . By now tourism employment has taken the first place in number and importance after the oil company had introduced computers in its operation. So tourism had grown to such an extent that hotel industry had become one of the major economic pillars of Aruba. 10

Local activity patterns may change as a result of tourism and travel activities more than they do as a result of, say, equivalent exports in manufacturing. Changes in behavior, including both production and consumption of goods and services, occur as a result of exposure to tourists and

\footnotetext{
${ }^{9}$ Source: Aruba Tourist Bureau, Unpublished Data, 1977. 10Hartog, Aruba, Past and Present, p. 251.
} 
travelers. Changes occur also because of new and different employment opportunities, both because of increased exposure and because of the kind of employment itself.ll

Even with deflated statistics an emphatic statement of the contemporary importance of tourism and travel in Latin America could be made by Victor Urquidi:

- . At present, tourism yields a net balance of nearly $\$ 550$ million, which is not large in relation to total export trade, but considered as an individual earner, is in fourth place after petroleum, coffee, sugar. Most of this income goes to Mexico (along its border) and a lesser amount goes to Haiti, Panama, and Uruguay. Argentina, Brazil, and Venezuela have negative travel balances. Tourism, at least in Mexico and the Caribbean, is expanding faster than any export product, and in ten years will probably be a major element in the general picture of Latin America' external demand. It will be determined primarily by the rate and level of disposable income in the United States, although in time it should benefit significantly from tourism of other countries.

\section{The Social Impact}

One of the neglected considerations in International Tourism is the assessment of the sociological impact of tourism.

Gearing, Swart and Var said in their book:

- . In general, travel experiences can have a profound effect upon the life of an individual traveler as well as upon a society. While the visitor is influenced by the contrast in culture

Il William $W$. Goldsmith, The Impact of the Tourism and Travel Industry on a Developing Regional Economy: The Puerto Rican Case, (Cornell University, Ph.D., 1968), p. 13.

12 Victor L. Urquidi, The Challenge of Development in Latin America, trans. Marjory M. Urquidi (New York: Praeger, 1964), p. 26 . 
observed in foreign countries or different section of his own country, the presence of visitors in a country also affects the living patterns of the host people.13

Erik Cohen emphasizes the potential dislocations that the impact of tourism can cause. ${ }^{14}$ He particularly draws attention to the fact that the developing economies, which most eagerly seek the economic advantages of tourism, are also the most vulnerable to the disruptions that likely will follow the rapid expansion of a tourist industry. He predicts that mass tourism in developing countries, if not controlled and regulated, will tend to destroy whatever is still left of unspoiled nature and of traditional ways of life. 15

According to Bryden, there are at least five potential benefits from tourism for any developing country, these are:

"1. A contribution to the balance-of-payments as an earner of hard currency;

"2. The dispersion of development to non-industrial regions;

"3. The creation of employment oppportunities;

"4. The effect on general economic development through the multiplier effects.

"5. The social benefits arising from a 'widening of people's interest generally in world affairs and to a new understanding of foreigners and foreign tastes." 16

${ }^{13}$ Charles E. Gearing, William w. Swart, Turgut Var, Planning for Tourism Development Quantitive Approaches. (New York: Praeger Publishers, 1967), p. 30 .

14 Erik Cohen, Toward a Sociology of International Tourism, Social Research (Spring 1972), p. 164.

15 Ibid.

16 John M. Bryden, Tourism and Development (Syndicates 
Dr. R.J. Sethna stated in his Caribbean tourism research report:

. . It has been reported that in 1973 approximately 215 million people were involved in tourism. One cannot ignore the impact of this mass movement of people, and the accruing of human interaction. Today, many developed and developing countries are facing ecological, economic, spiritual and social problems. There are many plans and programs being implemented by these countries in an attempt to reduce some of these problems. Many are looking for the tourist dollar to solve some of their difficulties however, the development of tourism is causing social changes in the life style of the people. 17

Goldsmith illustrates in his study that the tourismtravel industry emerges most clearly when viewed from two aspects: the structure of the population groups involved, and the structure of sectors of the industry. 18

\section{The International Tourism Growth}

The past twenty-five years have witnessed a remarkable world-wide expansion in tourism. The tourism phenomenon, as wahab calls it, and the consequent recognition of its potential to promote the economic growth of countries, have essentially been developments of the post-World War II era. The basic underlying cause of this has been the remarkable

of Cambridge University, Bently House, 1973), p. 71.

${ }^{17}$ Dr. R.J. Sethna, The Social Impact of Tourism (Caribbean Tourism Research Centre, 1971), p. 1.

18 Goldsmith, The Impact of Tourism and Travel Industry on a Developing Regional Economy: The Puerto Rican Case, p. 61 .

${ }^{19}$ Salah Wahab, Tourism Management (Tourin, Italy: Tourism International Press, 1975), p. 16. 
and sustained economic expansion experienced by the more advanced countries. 19

Krause, Jud and Joseph indicated in their study:

- The potential of the international tourism as a factor in Latin America's economic development, specifically, Mexico and the Caribbean is just beginning to obtain tourist business in substantial volume. 20

Given the current status of information on Latin America and the Caribbean tourist business, detailed forecasts of tourism demand are not possible though, within the broad range of available estimates of tourism potential, governments nonetheless can proceed with national plan for tourism business. 21

A plan so undertaken generally begins by defining the role of the private sector in the tourism program, then sets forth the objective(s) and extent of government participation in the industry.

By establishing and supporting a foreign-travel industry, governments necessarily assume a commitment to provide for the safety and fair treatment of foreign visitors. A minimal requirement for successful involvement is substantive political stability, with civil order and effective law enforcement. Again, quoting from Krause, Donald Jud and Joseph:

${ }^{19}$ Salah Wahab, Tourism Management (Tourin, Italy: Tourism International Press, 1975), p. 16.

${ }^{20}$ Krause, Jud and Hyman, International Tourism and Latin American Development, p. 8

${ }^{21}$ Ibid., p. 19. 
- . Additionally, the longer-range interests of the industry require that foreign tourists be protected against patently unfair business practices and that a plausible system for handling visitor complaints be on hand. In such matters government regulation can lend itself as a positive force to help insure the long-run growth and stability of tourism industry. 22

Jones quoted in his study:

- . The role of government is seen as the nost important single force in the contemporary approach to economic growth and development. Assuming that developmental resources are very scarce, only government is powerful and pervasive enough to force the institutional changes necessary to guide development, so that the maximum benefit to society is achieved.23

World Travel cited:

- . Since the industry is so important, with its octopus-like tentacles reaching deep into many sectors of life of a people and its government, the state therefore has to exercise its responsibilities to the full, determining the right tourist areas of development within the overall national policy and objectives, phase this development also in such a way as to ensure that it does not encroach upon all the other vital priorities of national development, upon other necessities--agricultural, industrial, social, etc. 24

\section{E. Summary}

World Travel, in its chapter "Constraints In the Tourist Industry" came to the following conclusion:

- . Tourism, we should know by now, is a vulnerable industry, as other industries for that matter, to a great or lesser degree. Ill planned or ill

\footnotetext{
22 Ibid., p. 21.

23 Fremon Jones, Tourism as a Tool for Economic Reference to the Countries of Jamaica, Trinidad and Guyana (Gainesville: University of Florida, 1970), p. 28.

24 World Travel No. 140 Jan.-Feb. 1978, p. 26.
} 
conceived, it can bring a rash of problems in its wake, environmental, political, social or economic. Those countries which have relied too heavily on the tourist dollar crop have come to harm or have had to rue their over-hastiness and lack of planning. Many examples come to mind of those countries that may be suffering from too rapid or excessive tourist development, making it difficult for them to tide over the present depression. Their economies--tourist or otherwise--could be suffering from overheating and we should not fall into the same trap. 25

25 Ibid., p. 27. 


\section{CHAPTER III}

TOURISM HISTORY AND ORIGINS OF TOURISM IN ARUBA

When discussing the previous tourism history of Aruba it is important to look back at its early history. Until 1956, almost no tabulations were kept except for the few happenings that were considered as Happening for the first time in the history of Aruba.

During the Spanish period (1500 - 1676) the island had been regarded as an "isla inutil" (useless island and as a consequence been neglected. English and Dutch ships were sighted near but they actually did not set foot ashore. Even the Spanish rulers of these islands did not visit Aruba.

It was Peter Stuyvesant, according to the Dutch records kept, who was the first visitor of Aruba in December 1742. Actually, he visited the island and took horses aboard so as to have some cavalry with which to act on his raids on the mainland of Venzuela.

The oil industry brought the first cluster of visits to the island between 1924 and 1928 where there are about 200 recorded schooner, yachts, motor vessels, tankers, and other vessels arrivals bringing American businessmen and visitors for the installation of the oil refinery.

The first tourist ship to call at the harbour was on the 3rd of February 1955, (Tradewind) which opened the new era in the history of the island. 
A. The Origins of Tourism in Aruba

In this section guest origins have been analyzed first by country. Secondly, since a major source of guest registrants was the United States, a detailed analysis has been provided by state.

The distribution of total guest registrants by country of residence during the period of December 1, 1977, to May 31, 1978, is given in Table 3.1 on the following page. 
TABLE 3.1

GUESTS BY COUNTRY OF RESIDENCE

DECEMBER 1, 1977 to MaY 31, $1978^{1}$

\begin{tabular}{lll}
\hline Country & Number & Percent \\
of Registrants & to Total
\end{tabular}

United States

Canada

Venezuela

Columbia

Other South America*

Puerto Rico

Other Caribbean**

Central America

Netherlands

Germany

Other Europe***

All other Countries

Total

No Response
14,489

955

3,671

609

207

151

835

94

338

59

423

155

21,986

370
$65.9 \%$

$4.3 \%$

$16.7 \%$

$2.8 \%$

$1.0 \%$

$.7 \%$

$3.8 \%$

$.4 \%$

1. $5 \%$

$.3 \%$

$1.9 \%$

$.7 \%$

$100.0 \%$

* All South American nations other than Venezuela and Colombia.

* All Caribbean nations other than Aruba and Puerto Rico.

*** All European nations other than Netherlands and Germany

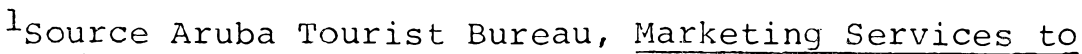
the Travel/Hospitality/Leisure Industies (Robinsons, Inc. January 1979), p. 12 
As indicated in Table $3.1,65.9 \%$ of all guests originated from the United States while an additional 4.3\% came from Canada. Thus, over $70.2 \%$ of all guests staying in Aruba between December and May originated from these two countries.

Venezuela, the second largest country of guest origin for Aruba, provided 16.7\% of the total registrants while Colombia furnished another 2.8\%. Other South American countries accounted for approximately $1.0 \%$ of total visitors, bringing the total from South America up to $20.5 \%$.

In terms of the Carjbbean, Puerto Rico accounted for only $.7 \%$ of guest and another $3.8 \%$ of all visitors came from various other islands throughout the region. Central America contributed only . 4\% of the guests during the period.

Europe, as a whole, also proved to be a relatively minor source of business. Only $3.7 \%$ of the guests came from Europe between December and May. As might be expected, however, over 4l\% of those Europeans lived in the Netherlands. German residents accounted for just over 7\% of European visitors while the balance of Europeans came from various countries on that continent. Only .7\% of the guests originated from various other countries. Since the United States represented such a large percentage of total visitations to the island, this country of origin will be examined next in Table 3.2 . 
TABLE 3.2

U.S. VISITORS BY REGION AND STATE OF ORIGIN december 1, 1977 to MAy 31, $1978^{2}$

Region and state

Number

Percent of Visitors to Total

1) New England:

Massachusetts

Rhode Island

563

104

New Hampshire

27

Maine

19

Vermont

22

Connecticut

Total New England

$\frac{490}{1225}$

$4.3 \%$

$.8 \%$

$.2 \%$

$.1 \%$

$.2 \%$

$\frac{3.7 \%}{9.3 \%}$

2) Mideast:

New Jersey

New York

1510

4222

Dennsylvania

885

Delaware

29

District of Columbia

57

Maryland

Total Mideast

$\frac{309}{7012}$

$11.4 \%$

$32.0 \%$

$6.7 \%$

$.2 \%$

$.4 \%$

$\frac{2.3 \%}{53.1 \%}$

3) Great Lakes:

Ohio

598

205

Indiana

811

Michigan

291

Wisconsin

1014

Illinois

Total Great Lakes

2919

$4.5 \%$

$1.6 \%$

$6.1 \%$

$2.2 \%$

$\frac{7.7 \%}{22.1 \%}$

4) Plains:

Iowa

Minnesota

North Dakota

South Dakota

Missouri

Kansas

Nebraska

Total Plains

\begin{tabular}{rl}
49 & $.4 \%$ \\
31 & $.2 \%$ \\
5 & - \\
- & - \\
74 & $.6 \%$ \\
55 & $.4 \%$ \\
23 & $.2 \%$ \\
\hline 237 & $1.8 \%$ \\
\hline
\end{tabular}

5) Southeast:

Virginia

129

$1.0 \%$

West Virginia

34

. $3 \%$

North Carolina

31

$.2 \%$

*Totals and subtotals may not add because of rounding.

${ }^{2}$ Source: Tourist Bureau Aruba. Marketing Services to the Travel/Hospitality/Leisure Industries (Robinsons, Inc., January 1979). 
TABLE 3.2 (continued)

Region and State

Number

Percent

of Visitors to Total

5) Southeast: (continued)

South Carolina

Georgia

Florida

Alabama

Tennessee

Mississippi

Kentucky

Louisiana

Arkansas

Total Southeast

6) Southwest:

Oklahoma

Texas

Arizona

New Mexico

Total Southwest

\begin{tabular}{rr}
18 & $.1 \%$ \\
108 & $.9 \%$ \\
624 & $4.7 \%$ \\
56 & $.4 \%$ \\
119 & $.9 \%$ \\
17 & $.1 \%$ \\
54 & $.4 \%$ \\
58 & $.4 \%$ \\
66 & $.5 \%$ \\
\hline 1314 & $\underline{10.0 \%}$ \\
\hline
\end{tabular}

80

205

10

$\frac{4}{299}$

$.6 \%$

$1.6 \%$

$-$

$\frac{-}{2.3 \%}$

7) Rocky Mountain:

Colorado

Idaho

Utah

Montana

Total Rocky Mountain

15

$.1 \%$

3 -

$\frac{2}{26} \quad \frac{-}{.2 \%}$

8) Far West:

Nevada

California

21

128

Hawaii

2

Oregon

Washington

Alaska

Total Far West

7
8
7

$\frac{7}{173}$

$.2 \%$

$1.0 \%$

$-$

8 -

Total Far West

$\frac{13205}{141}$

$\frac{-}{1.3 \%}$

Total USA

Other U.S. Territories

$100.0 \%$

No Response*

1143

*Insufficient information provided to determine city, state, or zip code. 
Table 3.2 shows that of the eight regions, the Mideast provided $53.1 \%$ of total U.S. visitors during the period. Within the Nideast region the largest contributing state was New York, with $32.0 \%$ of U.S. visitors, while New Jersey was the next major source and furnished $11.4 \%$ of total guests. Pennsylvania was a major contributor of visitors also, supplying $6.7 \%$ total guests.

Maryland contributed an additional $2.3 \%$ of the visitors while Delaware contributed less than two tenths of one percent. The District of Columbia, as defined by postal and political boundaries, also contributed only a small portion of visitors. However, when defined in terms of the Washington ADI (Area of Dominant Influence) the number of visitors increases slightly.

The second largest region providing U.S. visitors to Aruba was the Great Lakes region. Some $22.1 \%$ of U.S. registrants originated from the various Great Lake states. Illinois furnished the highest percentage with $7.7 \%$, while Michigan was next highest with $6.1 \%$. Ohio accounted for 4.5\% of U.S. registrants, Wisconsin less than half of that number at $2.2 \%$, and Indiana was lower yet at $1.6 \%$

The Southeast region was the next largest contributor of U.S. visitors. This region is large geographically. Encompassing 12 of the 50 states, and is the fastest growing regions in the country. In total, the southeast produced $10.0 \%$ of the U.S. visitors, nearly half of these visitors originated from Florida. Each of the remaining states 
accounted for only one percent or fewer of total visitors. The New England region produced $9.3 \%$ of the visitors. However, 8.0\% of these visitors were from Massachusetts and connecticut. The remaining four states in this region produced only $1.3 \%$ of the total.

In total, these four regions, representing the eastern half of the United States, produced $94.5 \%$ of total U.S. visitors.

of the remaining four regions in the western half of the United States, 2.3\% of the visitors come from the Southwest, 1.8\% from the Plains states, 1.2\% from the Farwest and less than . 2\% from the Rocky Mountain states. 
CHAPTER IV

THE ECONOMIC IMPACT

The establishment of the oil industry in Aruba in 1924 transformed the economics of the island. Increased job opportunities and higher wages brought a reasonable degree of prosperity to Aruba. In the early 1950s, the total number of workers in the refinery was over 3,000 . However, this number decreased steadily ever since, partly as a result of new refineries built in Venezuala, partly as a result of automation, and it is now approximately 1200.1

Aruba's economy from 1924 to the late 1950 s was only dependable on the oil refinery. Agriculture and cattle rasing were of little economic importance and together with fisheries provided employment for less than two percent of the labor force. Rainfall is insufficient. Furthermore, the soil is eroded as a result of deforestation and roving herds of goats. Fishing might be developed, but at the present time fish, like nearly all other goods for domestic consumption, is imported. In fact, the only

${ }^{1}$ UNESCO, Netherlands Antilles, Education Issues and priorities for Development (Advisory Services to member States in Educational Policy and Planning, Paris: June 1976), p.2. 
natural economic assets of the island are its good harbor, its location on the important trade routes, a good climate and sandy beaches.

The most striking development during the past ten years has been in the International Tourist Industry. The tropical climate, sandy beaches, good air connections, and government incentives, such as, tax remittance and freedom to open casinos, combined to attract large numbers of tourists.

In the following tables (Table $4.1-4.20, \mathrm{p}$. ) of statistics, we can follow the growth of the industry from 1958 to $1977 .^{2}$ In 1956, it has not been possible to secure earlier figures - 3,002 foreigners visited Aruba, regretfully, with no distinction between arrivals by air or cruise tourists. These visitors stayed at three different boarding houses totaling 30 rooms. The Strand Hotel opened in 1956 with 26 rooms and the Basi Ruti Hotel with 15 rooms in 1957.

From the tables we can see that the number of visitors increased almost 20 times in 19 years of successful tourism application. The significant increase was due to the fact that the island administration was actively engaged in the promotion of tourism, not only abroad, but also locally, and the American operated hotels who did their own promotions from which no advertising dollar was obtained.

\footnotetext{
${ }^{2}$ Source: Aruba Tourist Bureau.
} 
Relating the significant number of visitors to the total number of accommodations on the island, we can arrive at an overall occupancy rate for the island:

\begin{tabular}{lcccc}
\hline \hline Year & $\begin{array}{l}\text { No. of } \\
\text { Visitors }\end{array}$ & $\begin{array}{l}\text { Avg } \\
\text { Nights }\end{array}$ & $\begin{array}{l}\text { Room nights } \\
\text { Available }\end{array}$ & $\begin{array}{c}\text { \% } \\
\text { Occupancy }\end{array}$ \\
\hline 1959 & 7,209 & N/A & 41,760 & N/A \\
1965 & 25,524 & N/A & 85,060 & N/A \\
1970 & 75,042 & 6.5 & 332,640 & 63.8 \\
1975 & 128,852 & 7.7 & 528,960 & 73.9 \\
1976 & 146,487 & 7.0 & 545,760 & 82.4 \\
1977 & 151,169 & 7.3 & 611,550 & 73.8 \\
\hline
\end{tabular}

In the off-season, April 16 - December 15, the average hotel occupancy on the island ranges from 55\% to $60 \%$, while during the high season, December 16 - April 15, the average occupancy rate is $85 \%$ to $100 \%$; usually $100 \%$, which makes it very difficult and frustrating to find accommodations.

A. The Importance of the

International Tourism Growth

It is safe to assume that the inhabitants of Aruba are aware of the tourist trade. However, the importance of this industry to Aruba, simply is not appreciated.

Presently one can easily determine that tourism is one of the most vital pillars of the economy of Aruba. If this Industry for any reason should deteriorate, approximately

3 Ibid. 
$50 \%$ of Aruban families will not have a source of incorne and approximately 50\% of the workforce will be unemployed. In the luxury and first class hotels alone, we find that, in 1976, about 2,200 workers found a livelihood, which surpasses the employment figures of the oil industry. Research throughout the entire world has established, that for every job in a hotel, 2.5 - 4 jobs are created in related fields of tourism. This means, that for Aruba in 1976 about 7,700 workers held job in the tourist industry. This is about 42\% of the total work force. If we assume that in the average family, the husband, the wife, and one or more children are gainfully employed, then it follows, that about $50 \%$ of the families in Aruba depend to some degree on the tourist industry. ${ }^{4}$

The above statistics can be computed in a different

way:

$$
\begin{array}{lr}
\text { Labor force } & 22,800 \\
\text { Unemployed } & 4,400 \\
\cline { 2 - 2 } \text { Number of Employees } & 18,400
\end{array}
$$

Government employees/

including teachers

oil industry

5,000

construction

1,800

hotels

2,000

business \& trades

2,200

$1,900 \quad 12,900$

Miscellaneous tourist trade The total for the tourist trade $\frac{5,200}{2}$ and 5,500, for a total of 7,700 .

${ }^{4}$ Kuiperi M.S. and Estrada R.V., The Reorganization of the Aruban Tourist Bureau, (A study prepared by the Commission appointed by the island ordinance, March 17, 1976), p. 10 . 
The number of families in Aruba is about 14,000 from which one can conclude that about $50 \%$ of the families are dependent on the tourist industry. 
TABLES $4.1-4.20$ 
Table 4.1

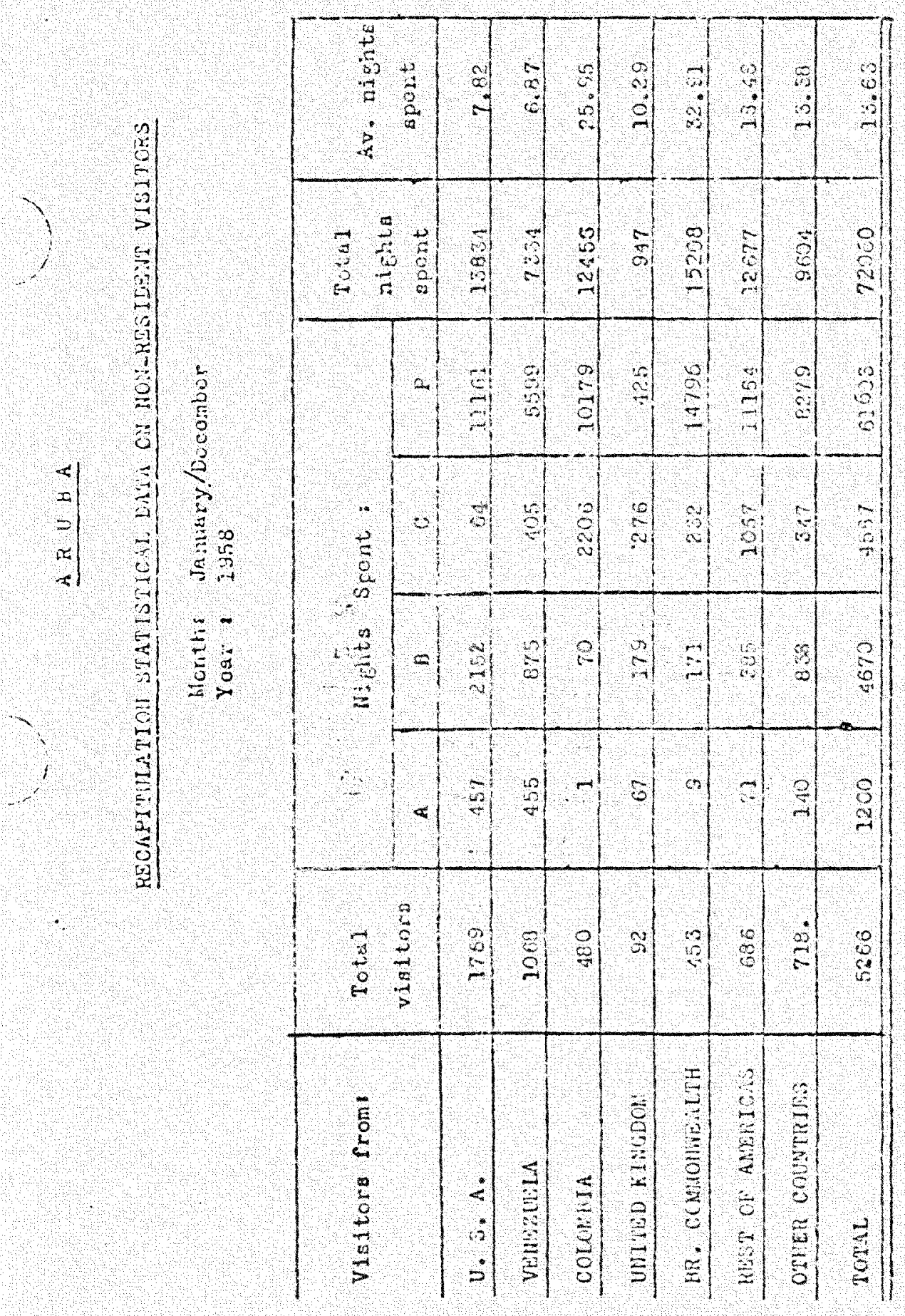




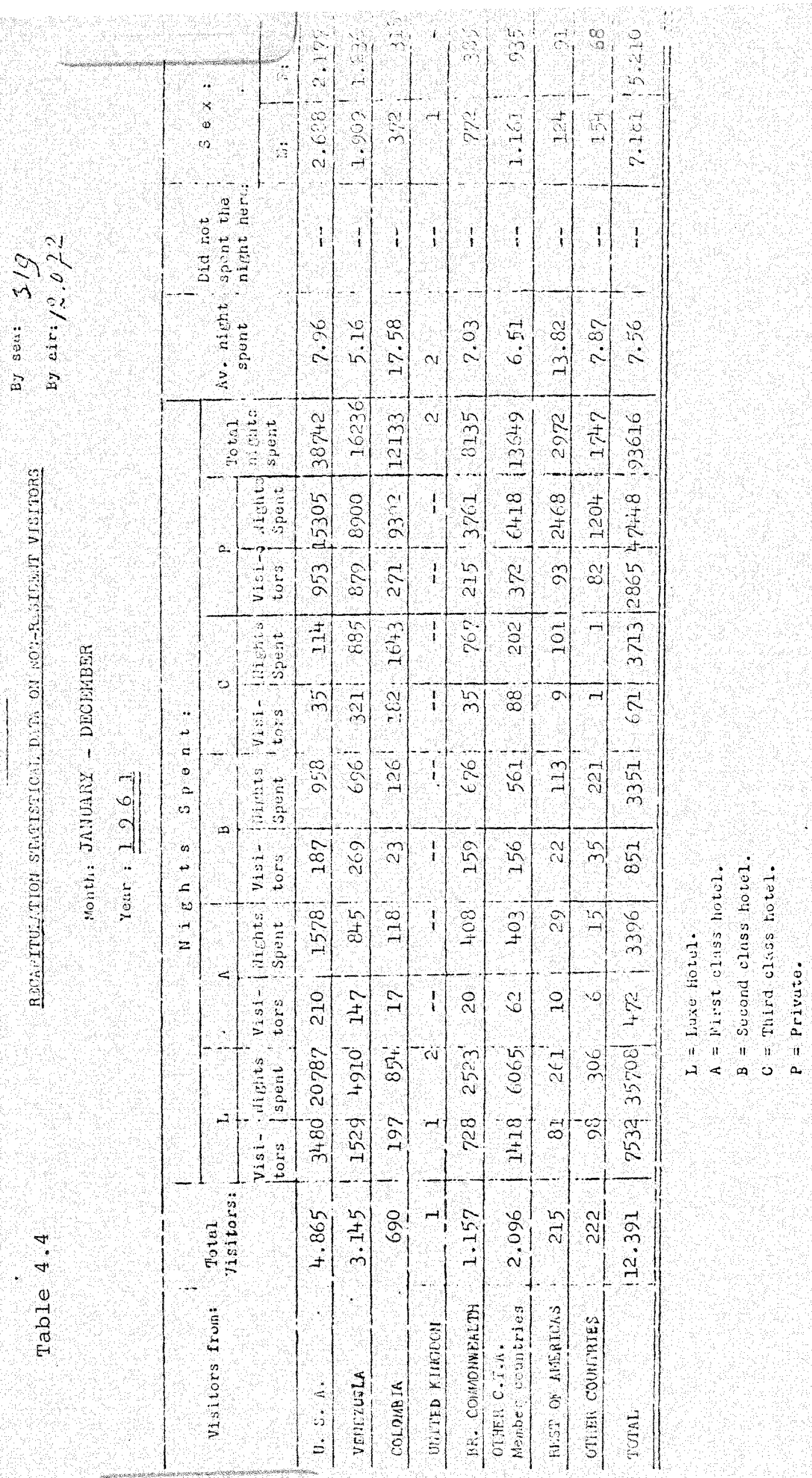




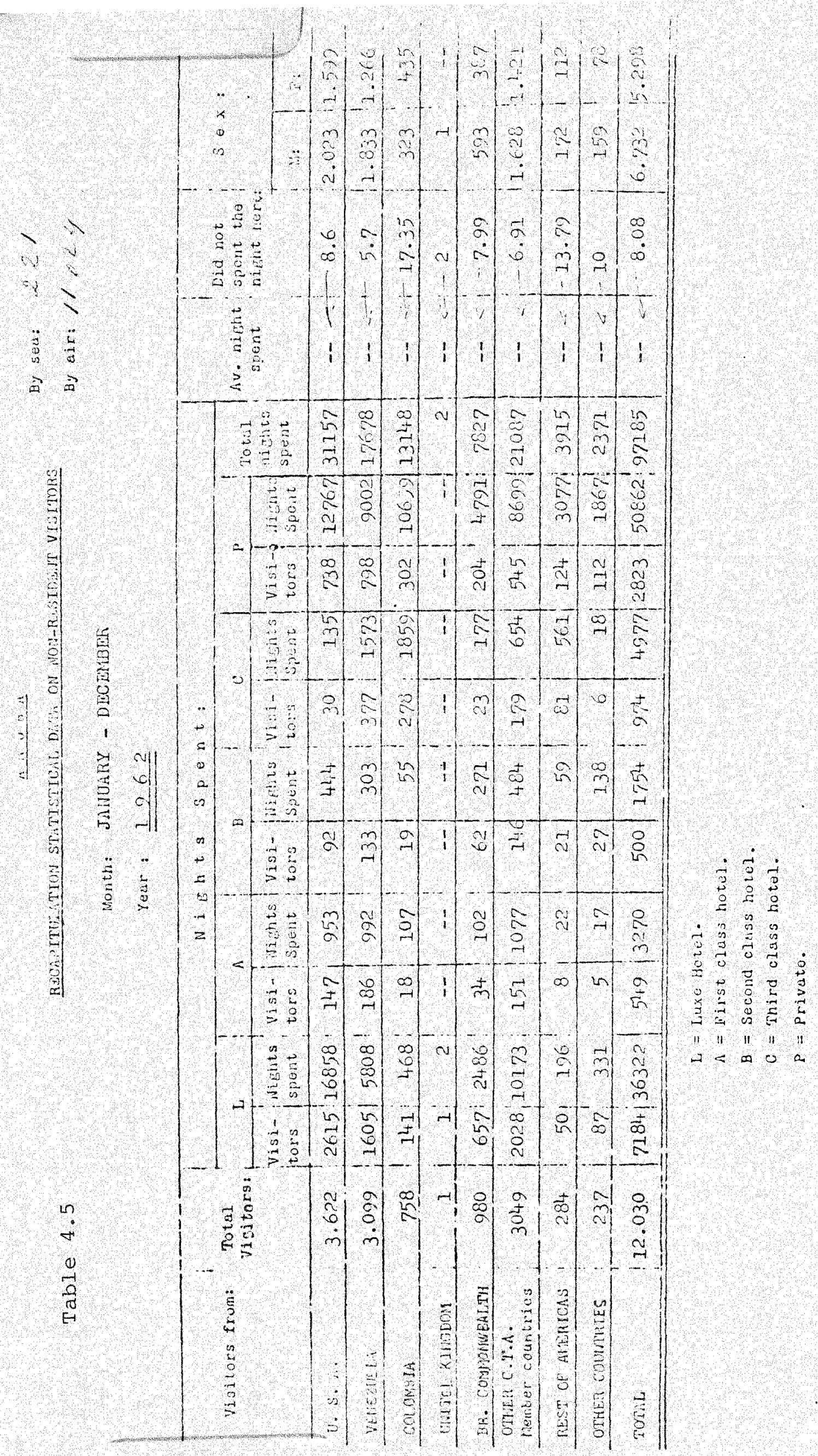



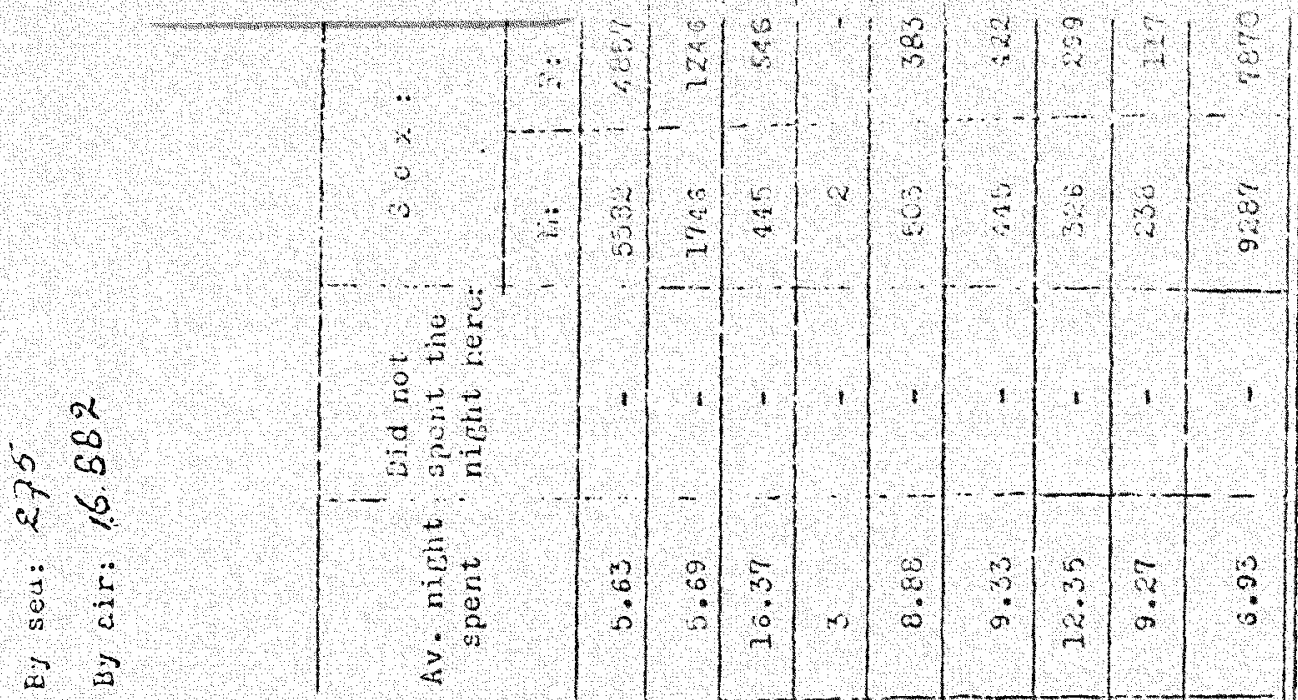

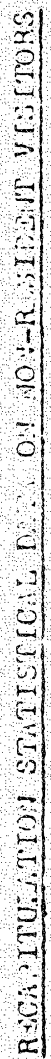

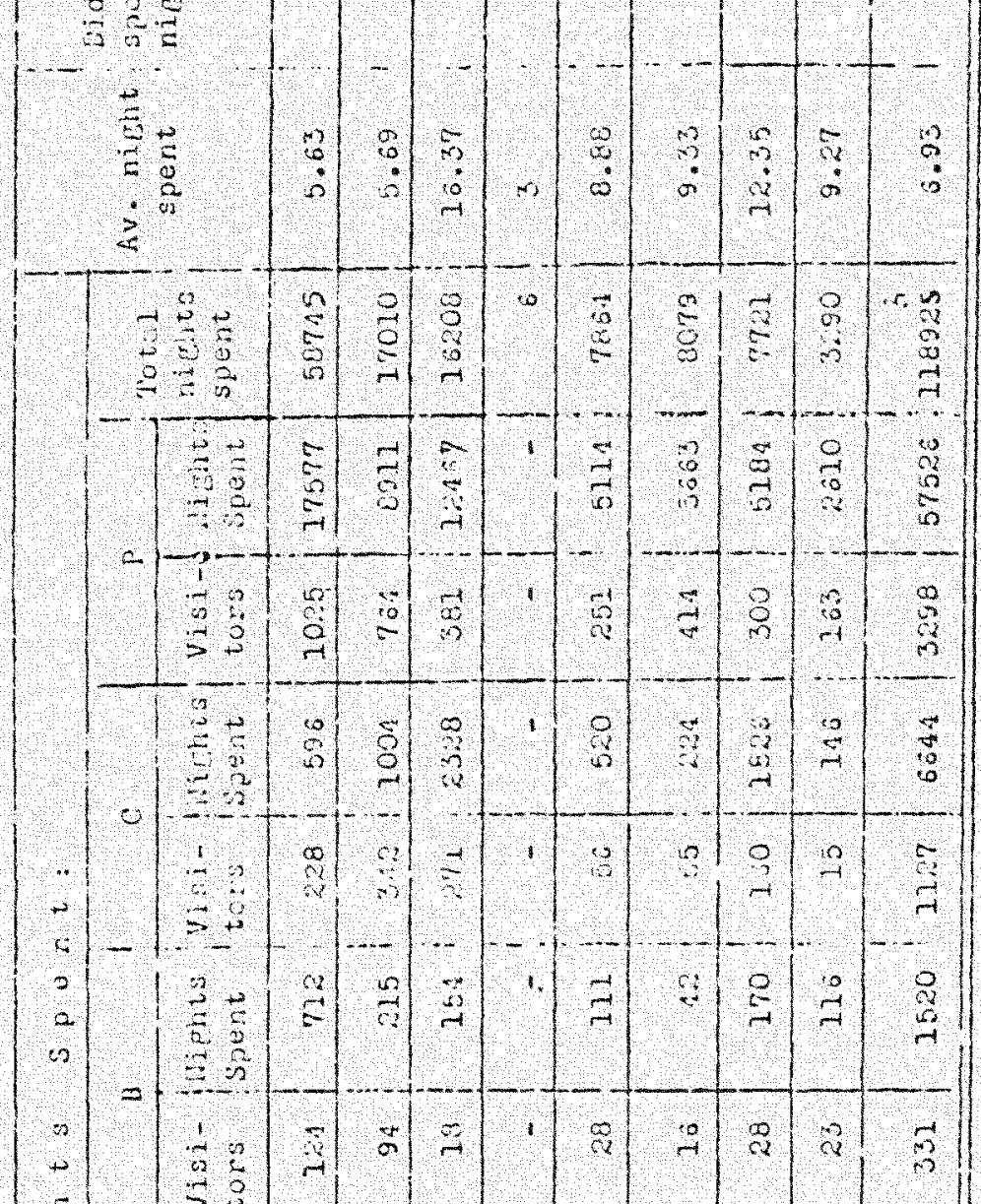

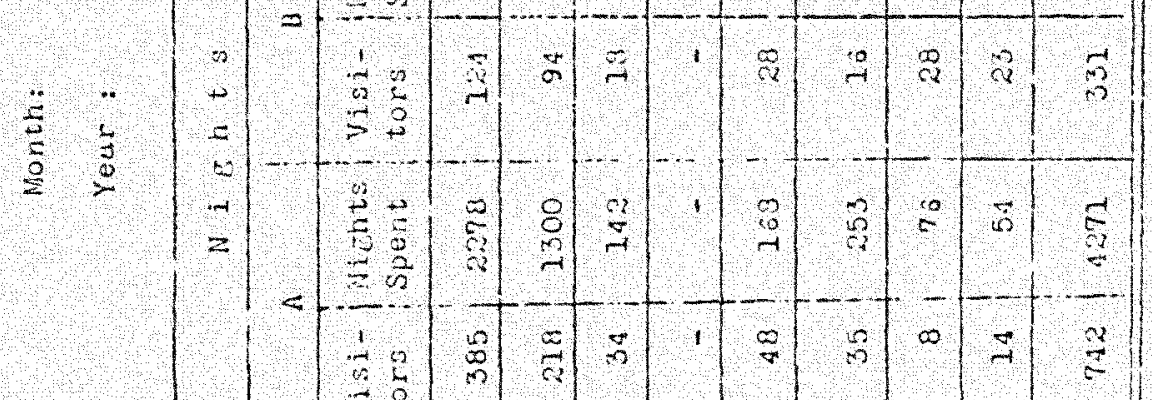

$\begin{array}{lll}3 & 1 & -1 \\ 3 & 9 & 3 \\ 0 & 9 & 0 \\ 2 & 0 & 2\end{array}$

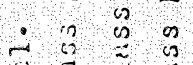

$\begin{array}{llll}3 & 5 & 5\end{array}$

$\because 0$ चै

$3: 3 j$

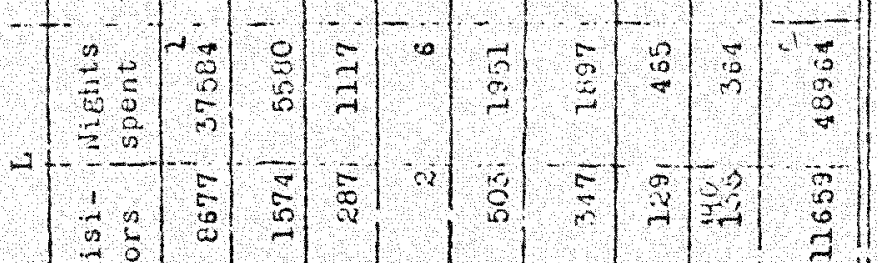

11 11 " 11

$\neg<\infty \quad 0 \quad a$ 


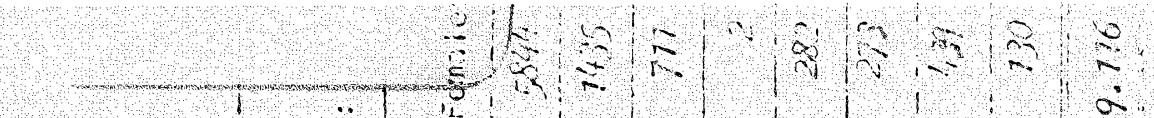

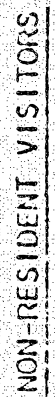

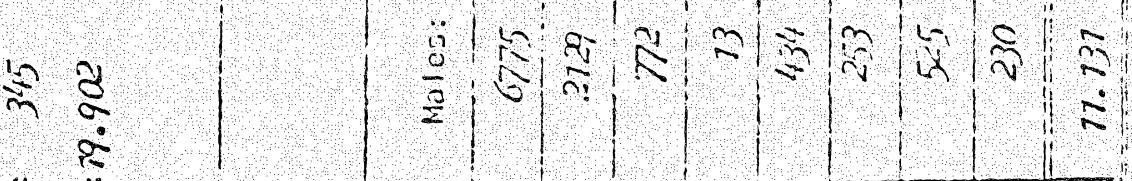
Q. के

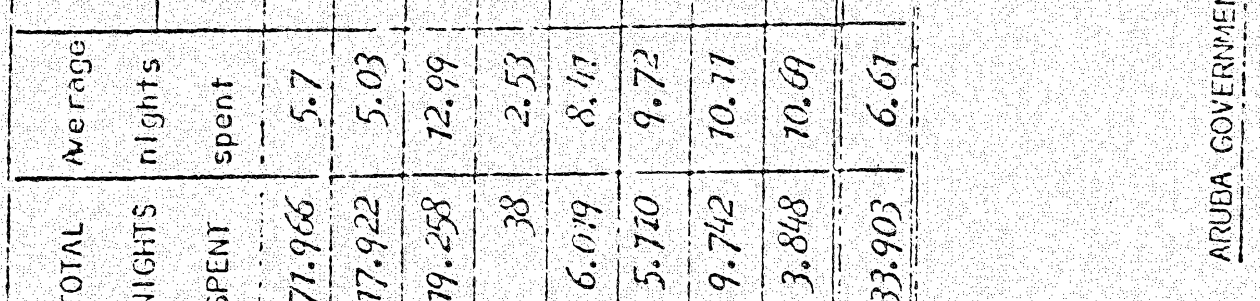

$+1$
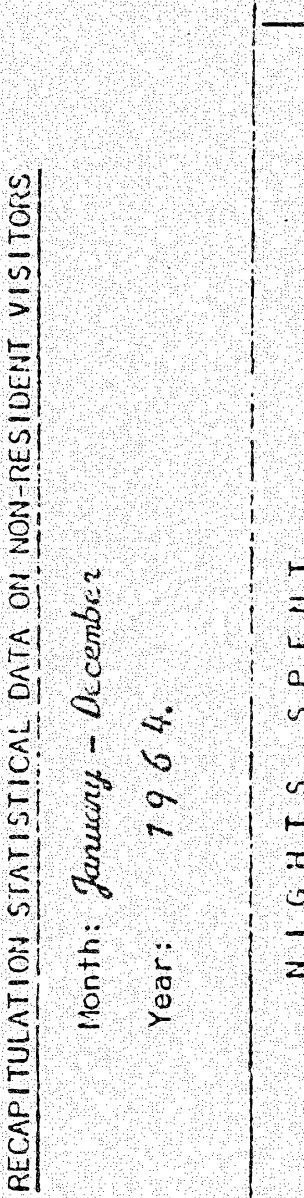

5
$\frac{5}{5}$
5
$\frac{5}{5}$
$\frac{4}{5}$
$\frac{5}{5}$
$\frac{5}{6}$
$\frac{5}{5}$
$\frac{5}{5}$
$\frac{5}{5}$
$\frac{5}{5}$
$\frac{5}{5}$
$\frac{5}{5}$
$\frac{5}{4}$

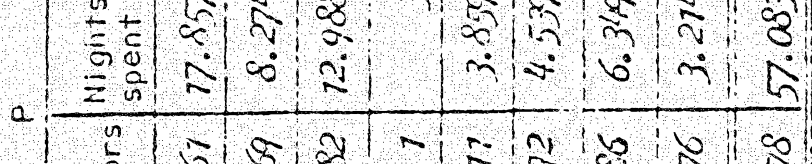

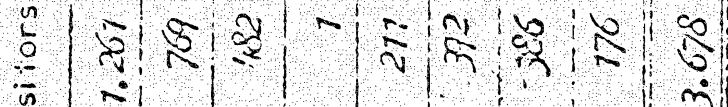

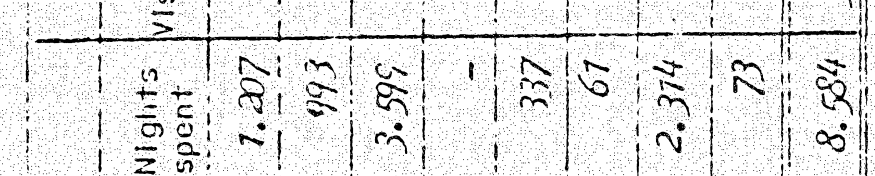

$0, \geq 0$

1, 1 दै

$\frac{n}{0} \div \frac{n}{0} \div$

$n \in$ \&

tin

$\therefore \frac{0}{0} \frac{0}{0}$

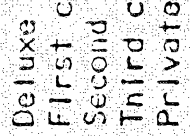

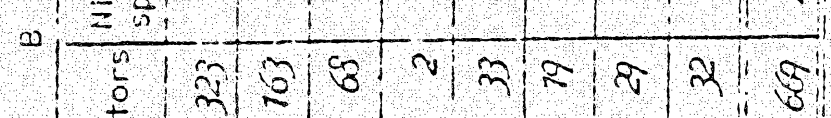

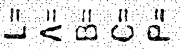

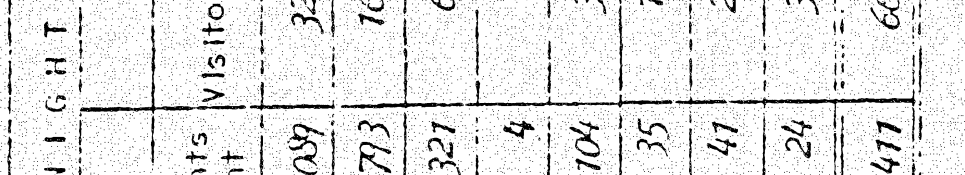

$r$
$\sigma$
$\frac{1}{0}$
$\frac{0}{0}$

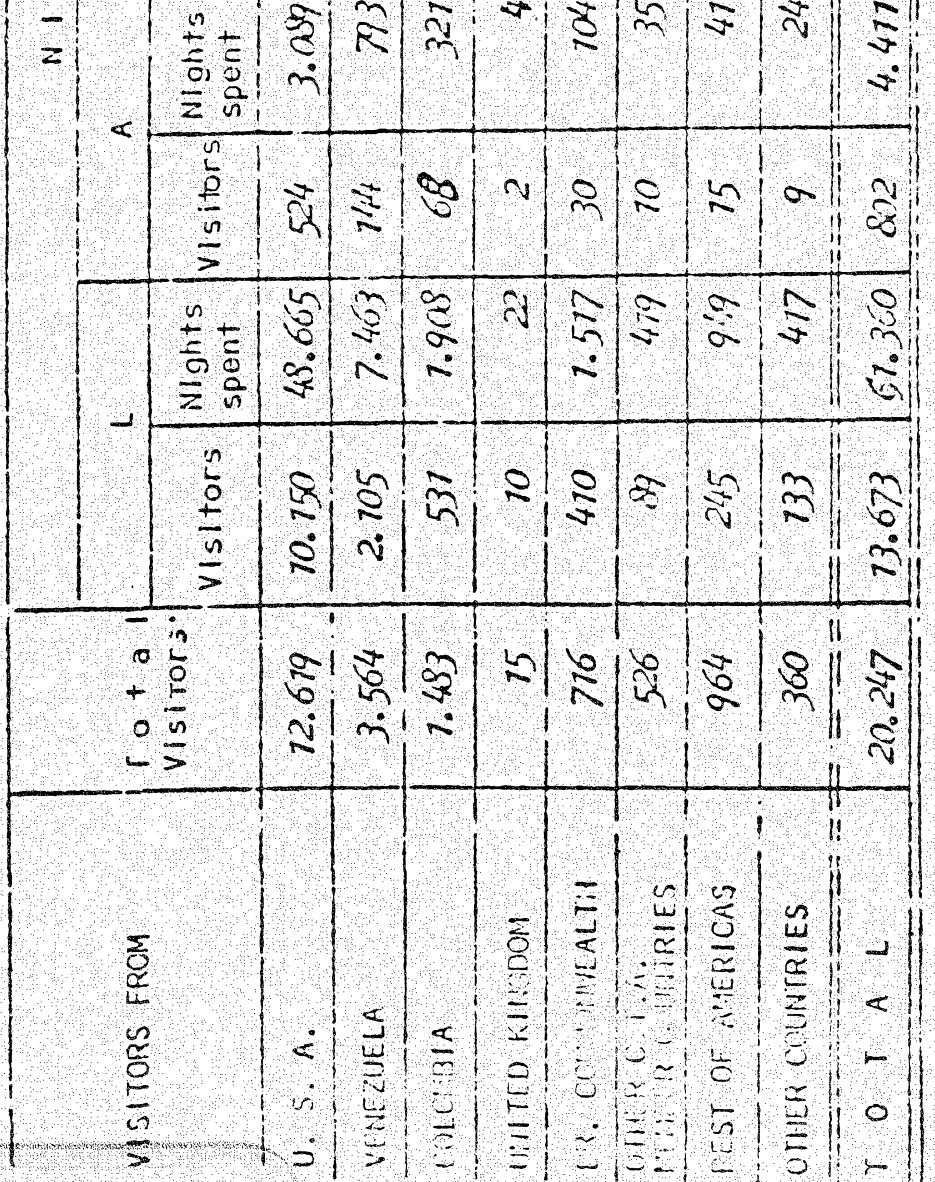




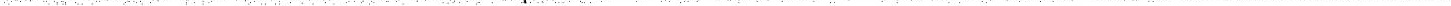




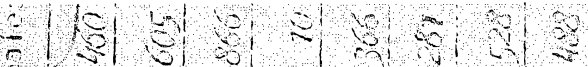

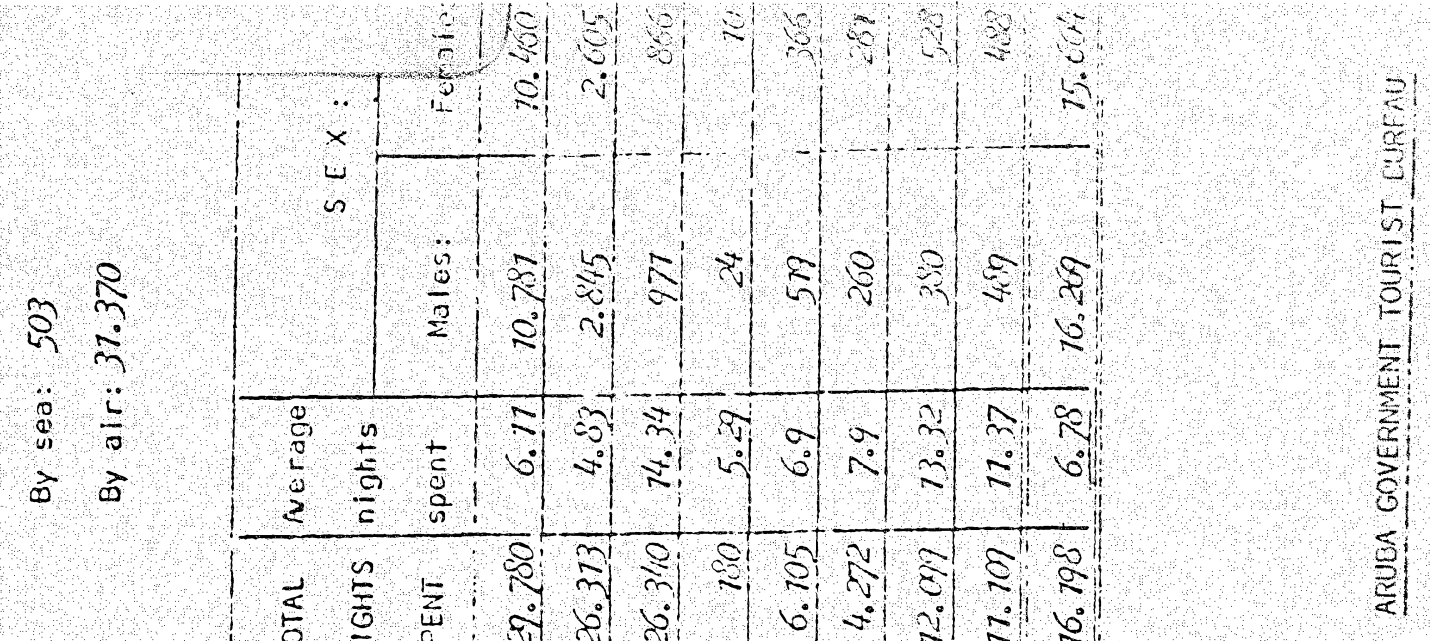

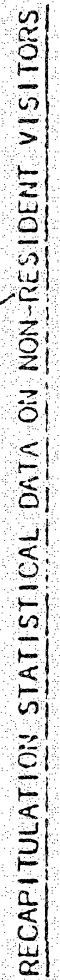

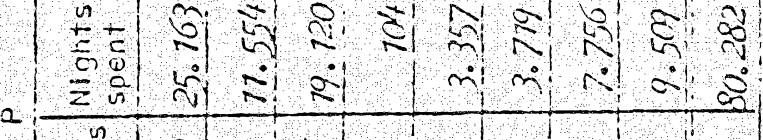

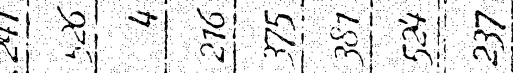

$$
\begin{aligned}
& =101>
\end{aligned}
$$

$<1$
$<$
$<$

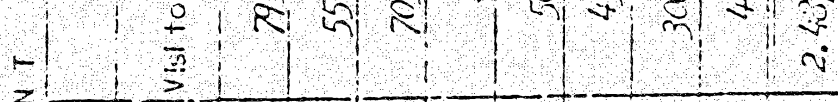

i $a$
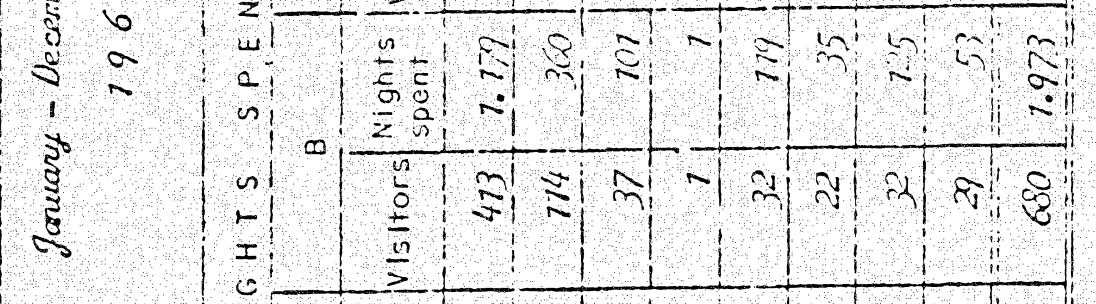

$n$
-
$I$
-
$=$

$\infty$,

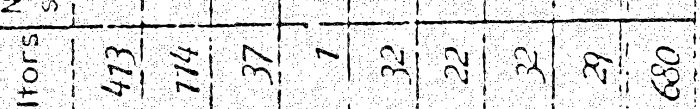

$\frac{0}{0} \div$

$n=2$

$\theta$ in 0

200

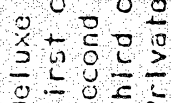

$8 \angle$ U $E$ a

$4 \angle 000$

0
-1
0
0
0
-1

$\stackrel{5}{5}$
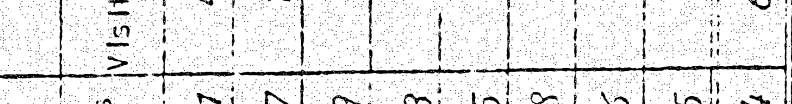

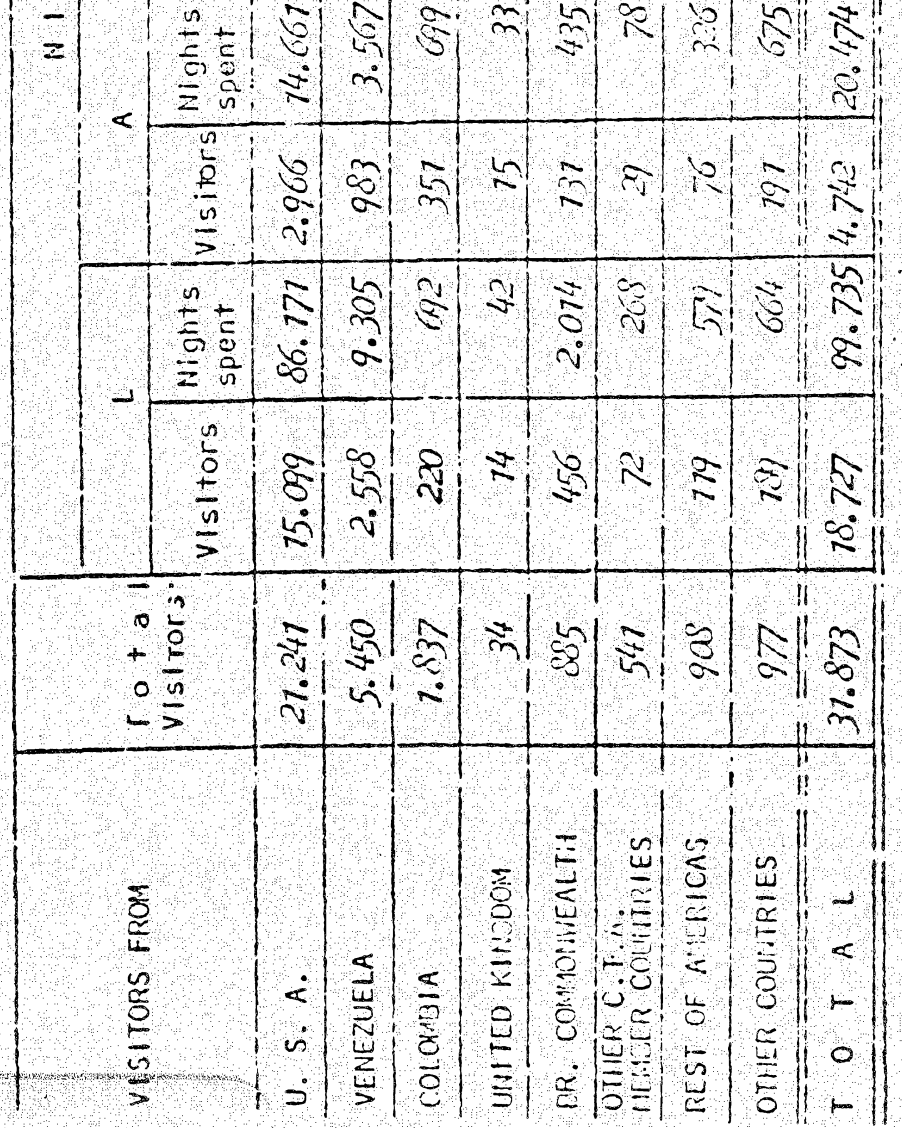




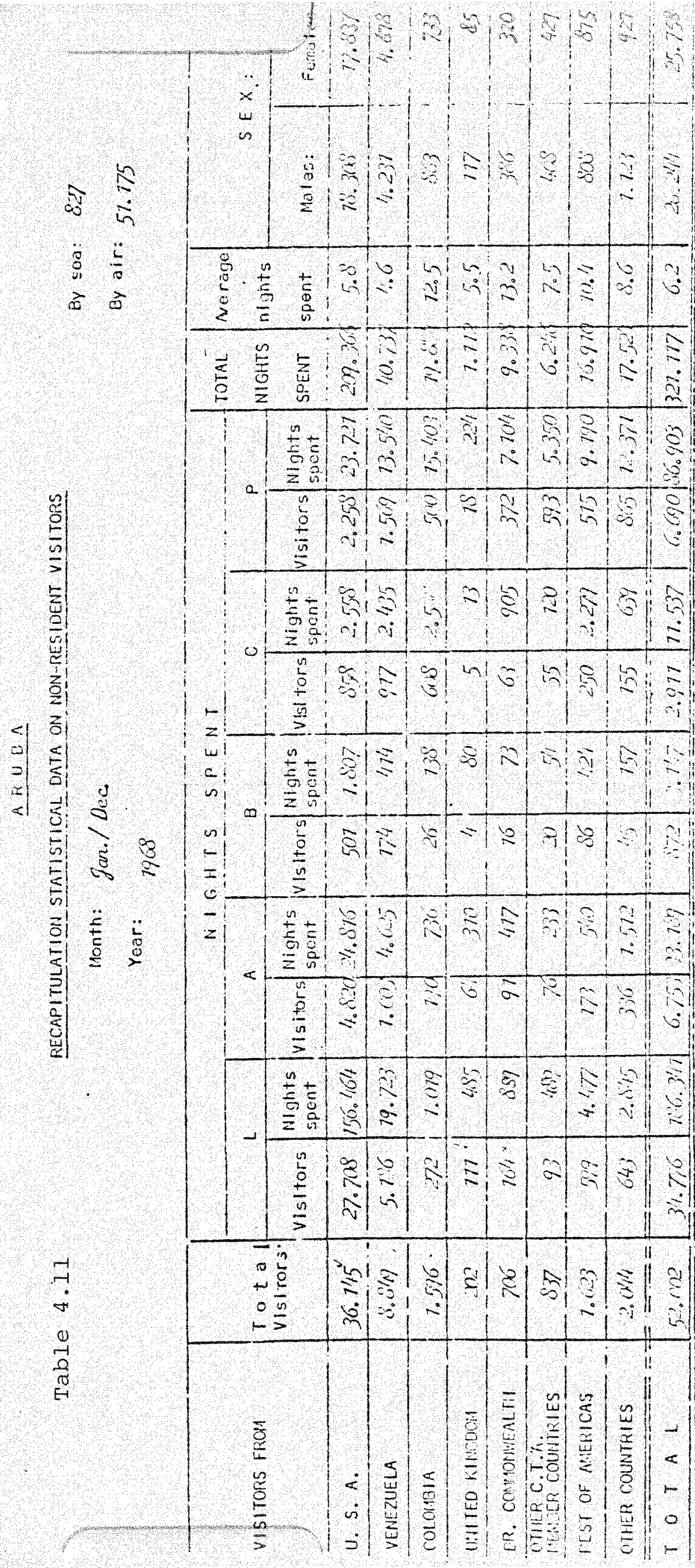




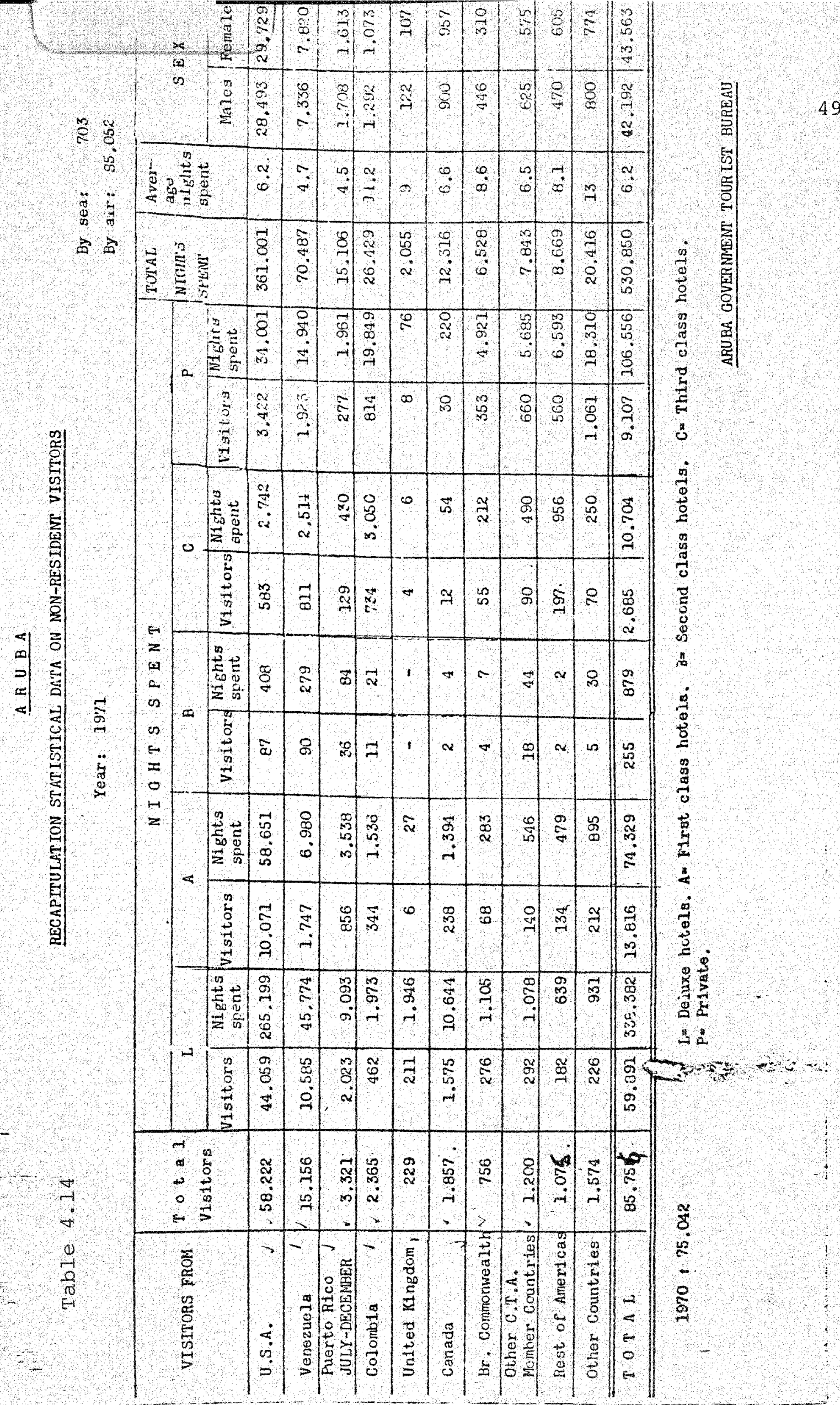




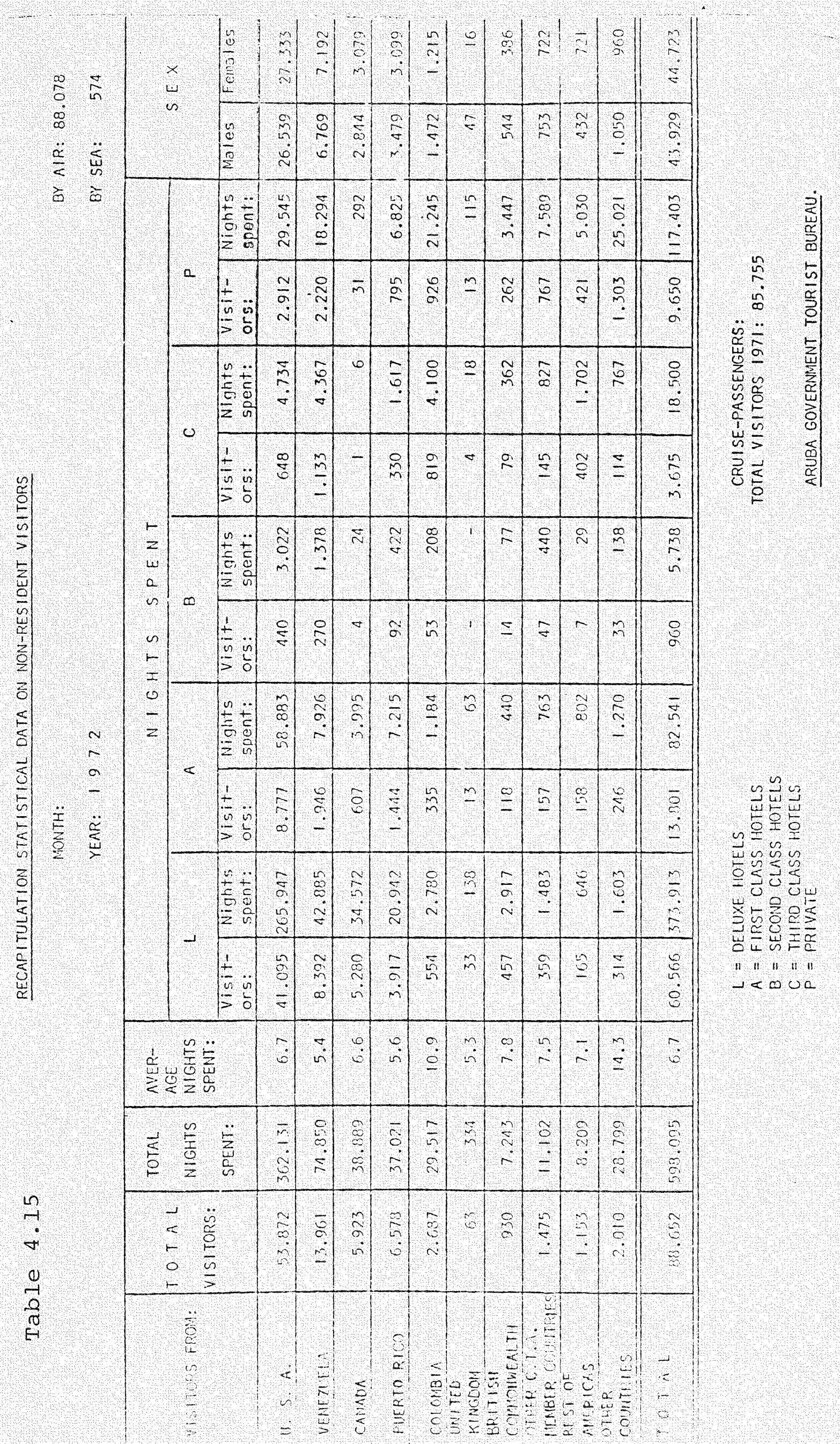




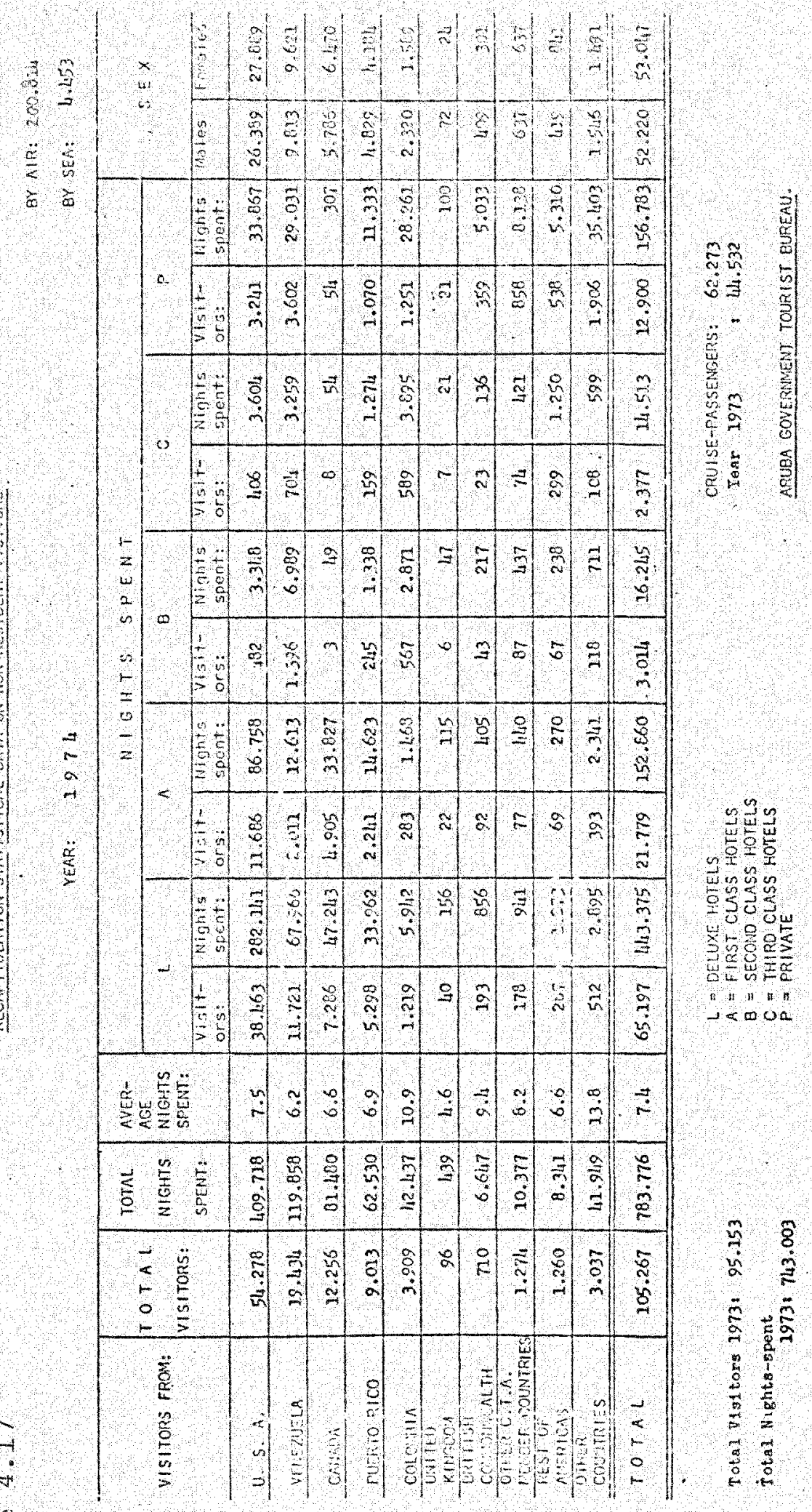


4

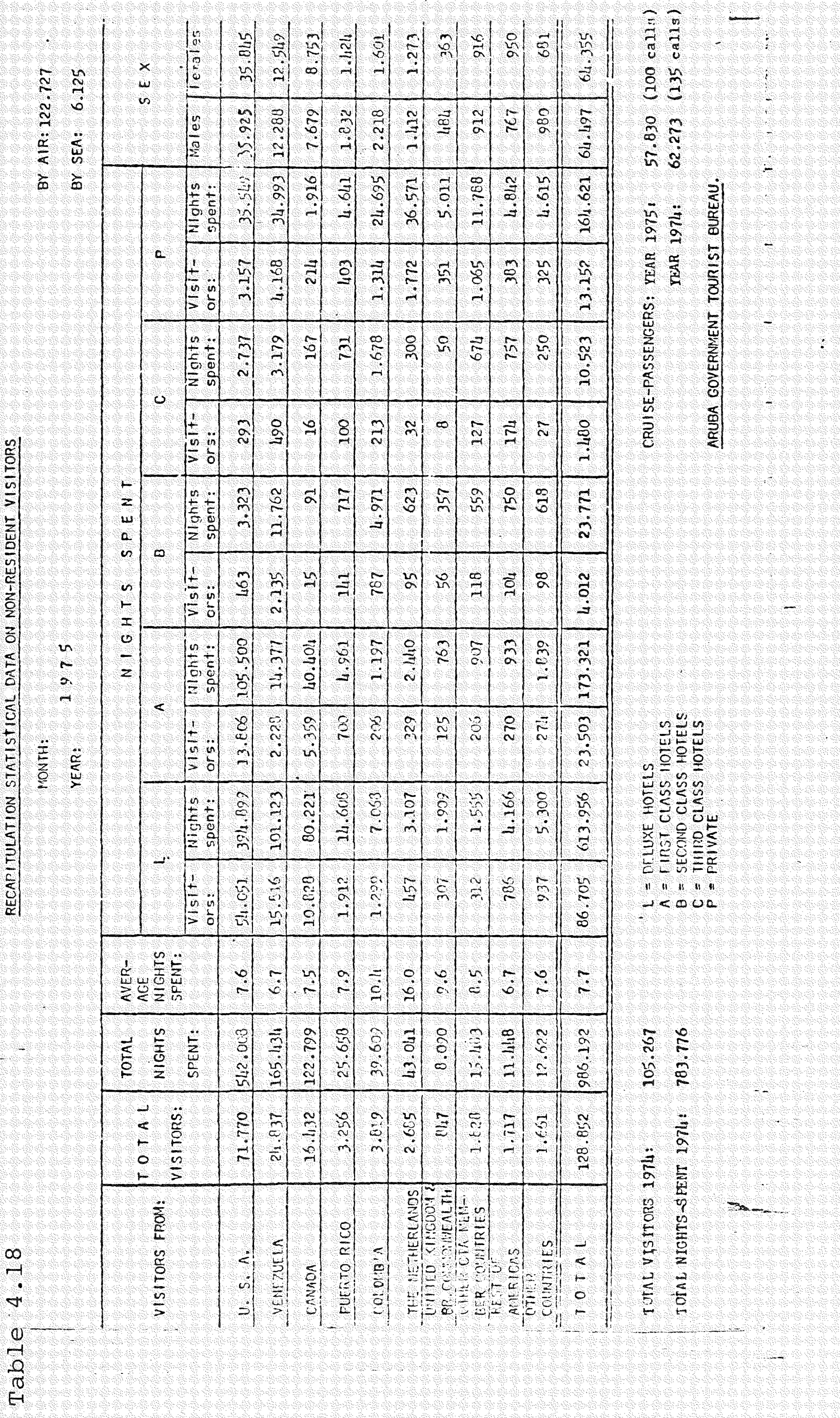




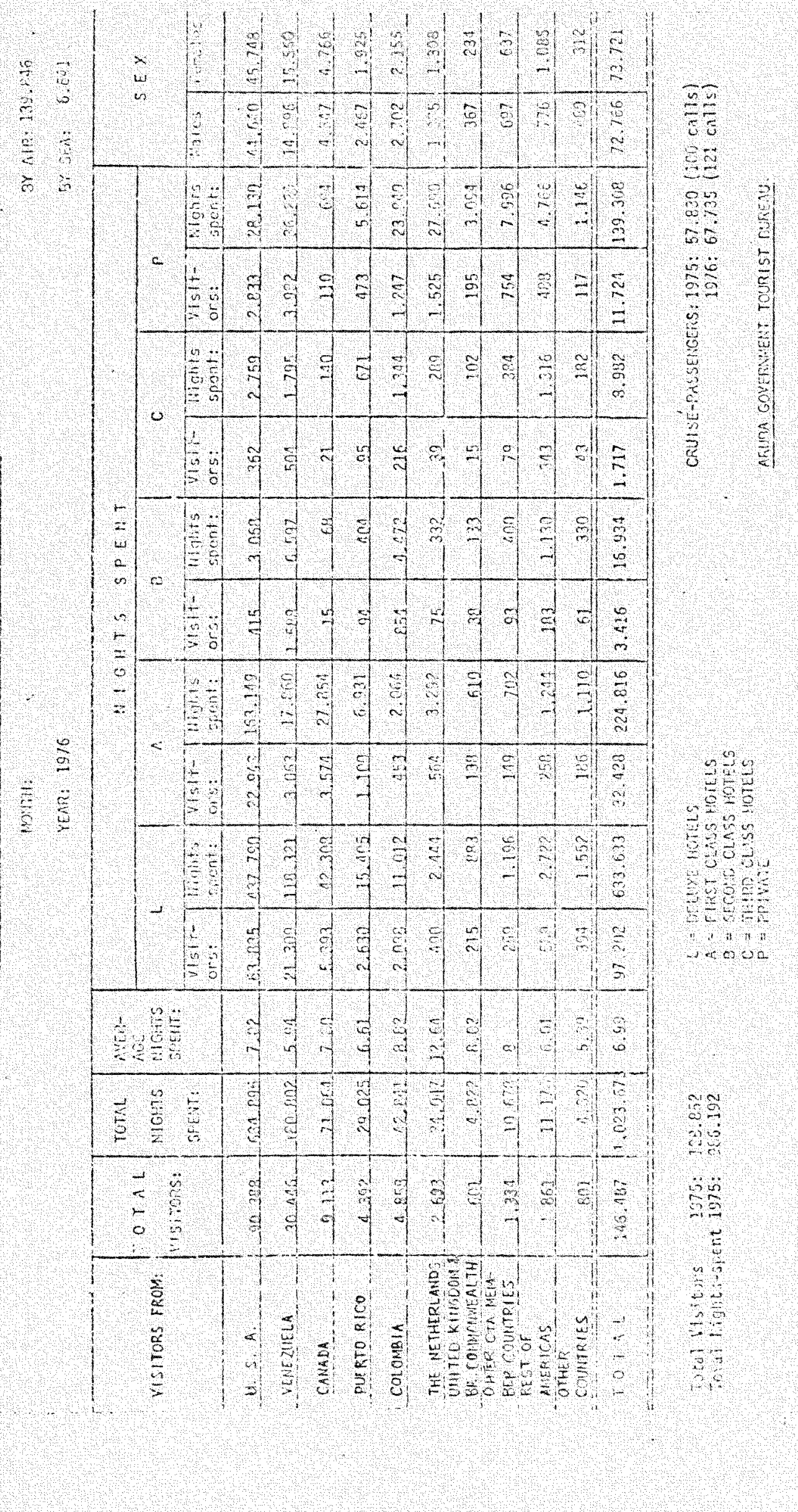


$\begin{array}{ll}3 & = \\ 3 & 5\end{array}$

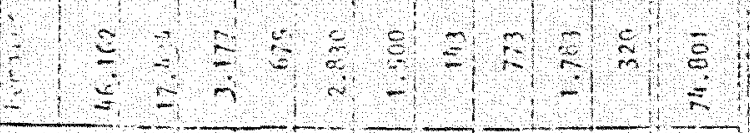

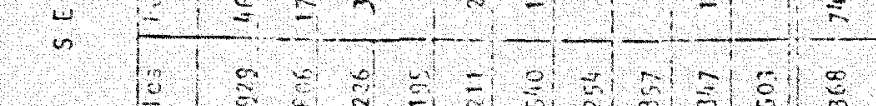

$\frac{5}{5}=$

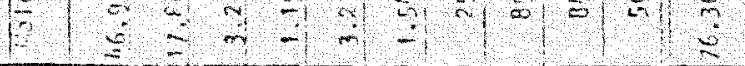

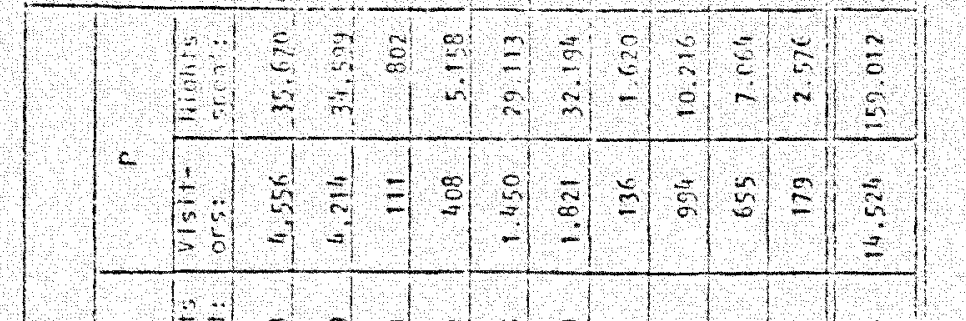

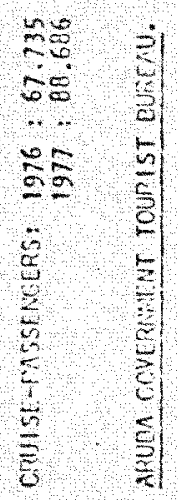

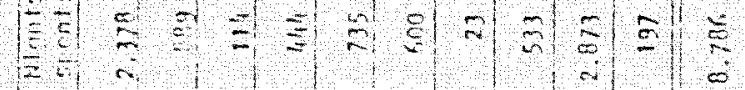
0

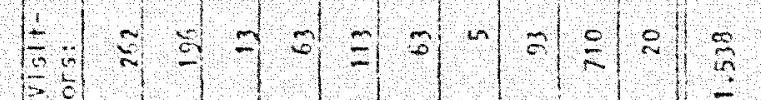

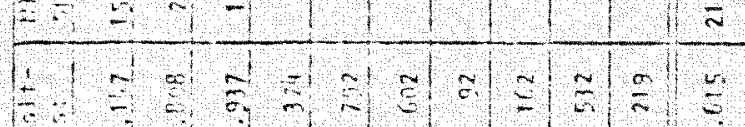

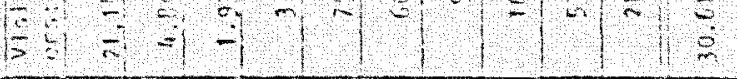

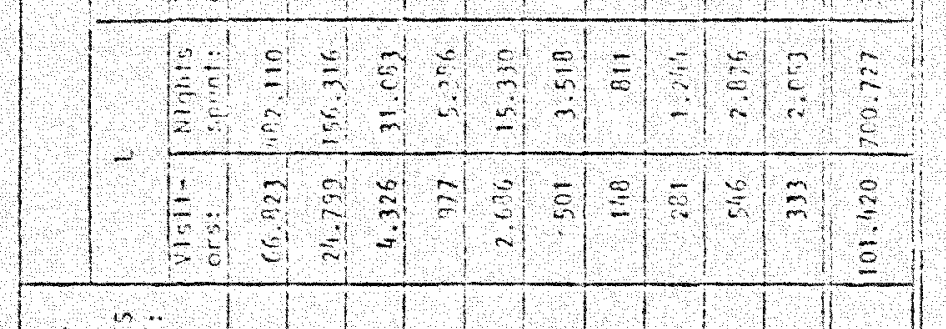

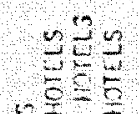

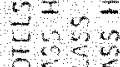

$=303$

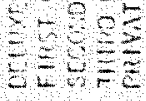

$\rightarrow a$. .

- « ए oc

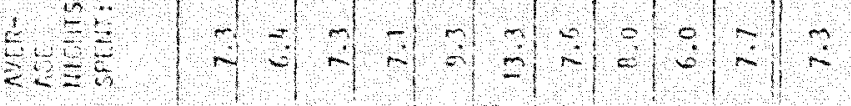

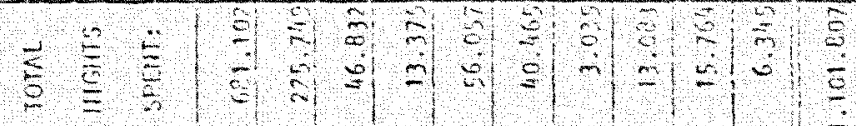

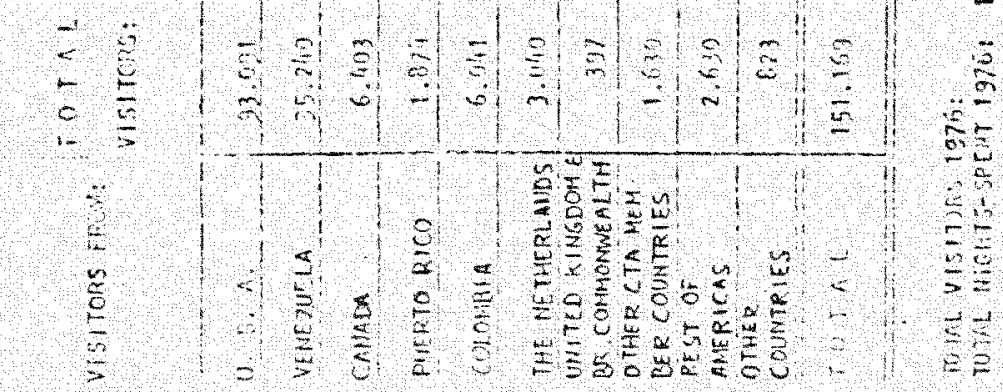


Table 4.21 illustrates the comparision of the labor force in 1974 and 1978. Again the hospitality sector which relates directly to the tourism industry is the largest employer in both years. An indication again that the tourism industry is one of the major contributor to the economy of Aruba. In 1978, the work-force in the Tourism Industry increased due to the opening of 500 room Concorde Hotel and the establishment of more free-standing restaurants. One can also notice that the once so important oil industry to the economy of Aruba is decreasing in its employment figures. Obviously, this industry still maintains its significance in the Aruban economy, but is not the biggest employer like in the early 1950s.

It is also obvious that the activities related to the Tourism Industry are the most important ones. But it has been noted, and this is really specific to Aruba, that the government is slacking the hotel investment motion. Anything is made to avoid a wild development. This is especially in the first place to maintain the actual occupancy level, which at the moment, has an average of over the $70 \%$ and, secondly, for not creating a labor problem for an island with a labor force of 24,000 people. Even in its present state of development, the Tourist Industry seems to encounter problems in recruiting employees. If we quote Robert W. McIntosh, he wrote: ${ }^{5}$

${ }^{5}$ J.R.W. McIntosh, Tourism, Prinicples, Practices, Philosphies (Columbus, Ohio: Gird, Inc., 1972), p.182. 
- . A further factor favoring tourism is its low requirement of costly "imported" manpower such as is frequently required for the operation of advanced industries. A recent study carried out in East Africa suggests that one new job is created for every $\$ 2,400$ of tourist expenditure. In other regions the ratio may be even higher. Tourism is also responsible for the creation of employment outside the tourist industry properly defined. In this respect it again scores noticeably over other forms of new industry. If these induced employment effects are included, i.e. increased employment in agriculture and the construction industry, the amount of employment for which tourism is responsible would increase substantially. The range of jobs created by tourism extends from unskilled through to management tasks. Insufficient attention is frequently paid to the importance of "management" in tourism. It should therefore be emphasized that one of management's essential functions is the operation of the tourist industry so as to obtain a satisfactory rate of return on capital employed. 
TABLE 4.21

WORKING LABOR FORCE 1974 and 1978

\begin{tabular}{|c|c|c|c|}
\hline Sector & Description & 1974 & 1978 \\
\hline 1 & Agriculture & 52 & 50 \\
\hline 3 & Oil Industry & 2127 & 2100 \\
\hline 4 & Utilities & 420 & 500 \\
\hline 5 & Construction & 2943 & 2000 \\
\hline \multirow[t]{3}{*}{$9 a$} & Government & 3300 & 4105 \\
\hline & Education & 823 & 895 \\
\hline & Household & 600 & 600 \\
\hline 6 & $\begin{array}{l}\text { Commerce and } \\
\text { Hotel,Casinos }\end{array}$ & 6349 & 9351 \\
\hline 7 & Transportation & 959 & 1050 \\
\hline 8 & Banking & 762 & 1450 \\
\hline \multirow[t]{2}{*}{$9 b$} & Others & 2833 & 2350 \\
\hline & TOTAL & 21168 & $24451^{6}$ \\
\hline
\end{tabular}

6Adapted from, Deelrapport I Tourism of Aruba, Chapter IV, 1978. 
The tourism industry has brought quite some changes on Aruba during its upward growth in the 1960 s to accommodate the mass movement of people. For example, the rapid growth of tourism made it necessary to adapt the airport accommodations to the new requirements of modern air traffic. The airstrip, which was built in 1964, was expanded and lengthened to 9,000 feet, more than sufficient for all large jet aircraft, including the Boeing 747 , now a regular visitor to Aruba.

Almost all of the international hotels are operated by American Hotel chain companies. According to the Department of Economic and Development Affairs the "Playboy chain of Hotels" and the "Melia" also would like to enter into the business in Aruba with respectively 500 rooms each, which would bring the total of hotel rooms in Aruba to 3,416. The infrastructure has been improved drastically and there is no doubt that this is true because of the overall development which the growing tourist industry has caused.

Merchants in the main shopping area have improved, or in some cases, rebuilt their stores to suit the flow and taste of the visitors. Many opening of free standing restaurants and night clubs have taken place in the last five years, offering different cuisines. In overall, many aspects of the industry have been improved or developed to suit the International Tourism and at the same time contributing to the Aruban economy. 
To give a comparison on the impact of the tourism industry on the G.N.P. of Aruba is very difficult because there are no statistics or reports available showing the G.N.P., even the G.N.P. of the Netherlands Antilles as a whole was not available. Even search for adequate information on expenditures, sales, and finally economic impact has been even more difficult. The form and degree of comprehensiveness of the data available have not permitted the kinds of interpretations necessary for adequate public or private decisions related to the International Tourist and Travel Industry. But as McIntosh stated: 7

- . We recognize that tourism's economic effects are manifested in two ways:

1. from the original investment,

2. from operations once the investment is completed.

These two effects are similar - and different. Both produce direct and induced effects throughout the economy. These may be summarized as: Major direct effects.

Production (the marginal capital output ratio)

Employment (the capital/employment ratio)

Balance of payments

Major induced (or indirect) effect

Income (the multiplier)

Investment (input-output analysis).

Major indirect effects:

Income (Tourism multiplier)

The multiplier is an income concept, not a transactions concept. For example, if a tourist were to purchase an import (to that country) in a gift shop, the immediate leakage effect reduces the number of rounds of spending and consequently the multiplier effect on income in that locality.

${ }^{7}$ R.W. McIntosh, Tourism, Principles, Practices, Philosophies (Columbus, Ohio: Grid, Inc., 1972), p. 181. 
Money spent by foreign visitors affects the economy of a country in a profound way. When a visitor pays his hotel bill, for example, the money received by the hotel management will be used to pay various debts incurred, or make outlays, in behalf of the international visitorelectricity, telephone, personnel, and other goods and services. The recipients, in turn, use the money received to pay their bills to satisfy their personal wants. Visitor money in this way may be spent several times, spreading into different sectors of the economy, each time giving rise to fresh income until "leakage" payments for imports, foreign investments, hoarding and other diversions takes money out of circulation. The unbroken series of conversion of visitor money constitutes the "multiplier effect." The greater the number of hands through which such money passes, the greater the beneficial effect on the gross national product and the national accounts. 8

For Aruba one can assume that the International

Tourism Industry had contributed a sum of NAf 443.6 millions

( 1 U.S. $\$=1.80$ Netherlands Antilles florins NAf) from

1973 to 1976 (Table 4.21A). The multiplier effect increases these receipts with a factor of 1.67 and provides as such an income base of about 620 million florins.

TABLE 4.21A

CONTRIBUTION OF TOURISM TO THE

ARUBAN ECONOMY 1973-1976 IN MILLIONS ${ }^{9}$

\begin{tabular}{lll}
\hline & Inflow NAf & Average Income \\
Year & (I US $\$=1.80$ NAf) & Per Night Spent
\end{tabular}

1973

1974

1975

1976
111.1

95.5

101.0

136.0
141.07

117.61

96.74

124.61

${ }^{8}$ Ibid., p. 184.

${ }^{9}$ Unpublished report of the Department of Economic and Development Affairs, 1977. 
The reason of the relative decreasing of income of resort-tourism in Aruba from 1973 to 1975 have to be sought in the development of the mass tourism. It regards here to the essential problem, that luxurious tourism and mass tourism at a certain point do not go together.

In 1976, we can see a relative increase of income, reason for this increase can be: price adjustments, growth of shopping tourism and junkets.

\section{B. The Hotel Sector}

The largest, most noticeable, and probably most important component of the visitor industry in many regions is the hotel sector. In Aruba this is certainly the case. Although it is obvious that the economic impact of such a large and dynamic sector must be important to the Aruban economy, particularly because a large portion of hotel income is derived from exports, just what portion of hotel sales are made to visitors, what goods sold are imported (directly or indirectly) and how hotel income is distributed, have not been determined by studies of the industry. However, this section will reveal the total amount of hotels and hotel rooms; type of hotels; type of visitors; length of stay; number of adults per party; number of children per party; spending patterns of visitors; daily room paid and stay plan of visitors.

In the table of the development of hotel accomnodation on the next page we can see that Aruba entered the 
tourism era with 26 first class rooms and within 19 years

it had 1,590 luxury, 442 first class, and 116 commercial rooms.

The economic impact of tourism cannot be underestimated:

1. The 1.1 million nights spent in Aruba produced 2.2 million dollars in room revenues. (1.1 $\mathrm{x} \$ 20-$ average rate/night per person).

2. The expenditures on food and beverage per night averaged another $\$ 20$, producing another 2.2 million dollars.

3. The hotels have spent over half of their revenues to local services: wages, utilities, insurance, local foods, entertainment, taxes.

4. Tourists have spent sizeable amounts in the casinos. A significant amount of this revenue was funneled via taxes, back to the economy.

5. Continuing construction and expansion of hotels, created job opportunities for hundreds of unskilled laborers. In spite of its seasonality, the construction industry has developed in a solid way. 10

10Source: Department of Education, (A study prepared by Z. Lavon 1978), p. 36. 
TABLE 4.22

DEVELOPMENT OF HOTEL ACCOMMODATION

NUMBER OF ROOMS PER TYPE OF ACCOMMODATION ${ }^{11}$

\begin{tabular}{|c|c|c|c|c|}
\hline Name of Hotel & $\begin{array}{l}\text { Year of } \\
\text { Opening }\end{array}$ & Luxury & $\begin{array}{l}\text { First } \\
\text { Class }\end{array}$ & Commercial \\
\hline Coral Strand & 1956 & & 26 & \\
\hline Expansion & 1970 & & 38 & \\
\hline Basi Ruti & 1957 & & 15 & \\
\hline Aruban Caribbean & 1959 & 140 & & \\
\hline Expansion & 1966 & 80 & & \\
\hline Astoria Hotel & 1959 & & & 10 \\
\hline Cactus Inn & 1964 & & & 20 \\
\hline Hotel Central & 1964 & & & 25 \\
\hline Manchebo Beach & 1966 & & 72 & \\
\hline Aruba Sheraton & 1968 & 202 & & \\
\hline Hotel Caribana & 1968 & & & 16 \\
\hline Aruba Holiday Inn & 1969 & 200 & & \\
\hline Expansion & 1975 & 200 & & \\
\hline Divi Divi & 1969 & & 104 & \\
\hline Expansion & 1975 & & 44 & \\
\hline Victoria Hotel & 1970 & & & 30 \\
\hline Americana Hotel & 1975 & 200 & & \\
\hline TamarijnBeach & 1975 & & 158 & \\
\hline Aruba Beach Club & 1977 & 133 & & \\
\hline Aruba Concorde & 1977 & 435 & & \\
\hline Total & & 1590 & 442 & 116 \\
\hline
\end{tabular}

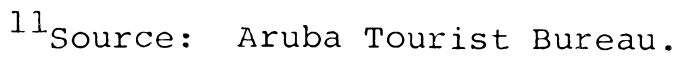


Guest type includes the following categaries. ${ }^{12}$

1. Foreign Individual Traveler (FIT) which includes guest traveling alone (not affiliated with a group), and paying full rate for their accommodations.

2. One-Stop Tour Charter (OTC) which includes guests traveling as part of a charter (tour) group.

3. Group Inclusive Tour (GIT) which includes guests traveling either alone or with a group (not a charter group) who are paying a reduced rate for their accomodations.

4. Incentive Traveler which includes guests traveling as part of an incentive group.

5. Junket Traveler which includes guests traveling on gambling junkets and casino guests.

6. Conmercial Traveler (COMM) which includes guests traveling on business and paying a commercial rate for their accomnodation.

7. Conference and convention (CONF) which includes guests traveling solely for the purpose of attending a business meeting or conference.

8. Other Travelers (OTH) which includes all other guests, guests receiving complimentary accommodations; special guests of the hotel recciving discounted rates (e.g., travel agents, travel writers, etc.)

The percentage of visitors staying for various numbers of nights by type of guest and month of arrival is given in Table 4.23 and Table 4.24 on the following pages.

As indicated in the two Tables, the average length of stay for all guests between December 1979 and May 1978 was 5.2 nights. The most frequent stay periods were seven nights (30.5\%) for the visitors and five nights (16.5\% of

12Source: Aruba Tourist Bureau, Marketing Services to the Travel (Hospitality) Leisure Industries (Robinson, Ind., January 1979), p.2. 
the visitors). Other lengths of stay typically ranged from one to four nights, and six nights. Nearly $91 \%$ of all visitors stayed 7 nights or less, while fewer than $1 \%$ stayed on 14 nights.

FIT guests averaged about 5.1 nights on their length of stay, but far more FIT's versus total guests (47.9\% FIT compared with $30.5 \%$ total visitors) stayed 4 nights or less. Only 25.9\% of the FIT guests stayed seven nights. Conversely, the majority (79.3\%) of OTC guests stayed seven nights, while $2.4 \%$ of this group, twice the average for all visitors, stayed 14 nights. Consequently, the OTC's average length of stay was higher than any other group, at 6.7 nights.

The most popular length of stay among junket travelers was 5 nights. Approximately $61.8 \%$ of the junket visitors stay 5 nights, while nearly $85 \%$ of this group stay between 4 and 7 nights. 13

The majority of commercial travelers (66.8\%) stay 3 nights or less, although an additional 25.6\% stay between 4 and 7 nights. Conference travelers had the shortest length of stay, only 2.4 nights. In addition, only $5.6 \%$ of all conference visitors stay longer than 4 nights.

As indicated in Table 4.24, there was some variation in length of stay averaged 5.6 nights, in January the stay increased to 5.5 nights, and in February, the average length of stay peaked at 6 nights. During the following three months

$$
{ }^{13} \text { Ibid., pp. 39-43. }
$$


average length of stay declined to 5.2 nights in March, 4.8 nights in April and 4.6 nights in May. No appreciable differences in the frequency distribution of number of nights was evident with the exception of February, where a greater percentage of 5 and 7 nights stay occurred than during any of the other months. 


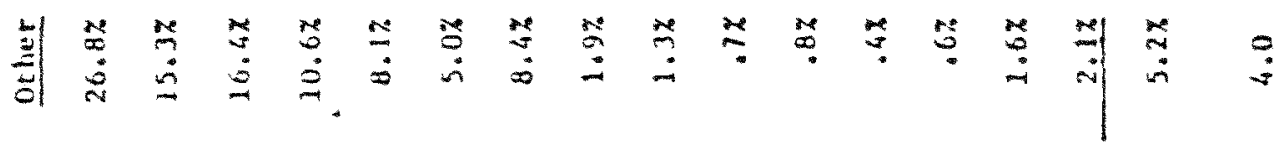

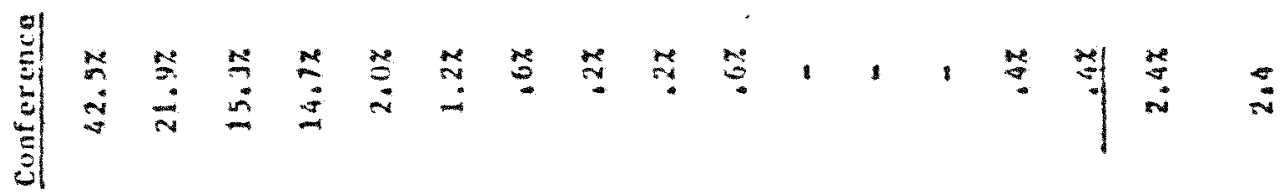

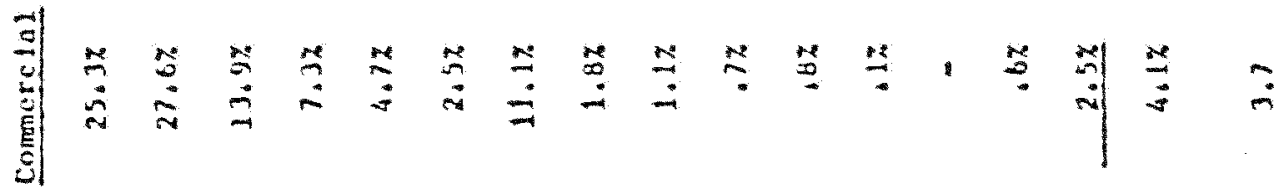

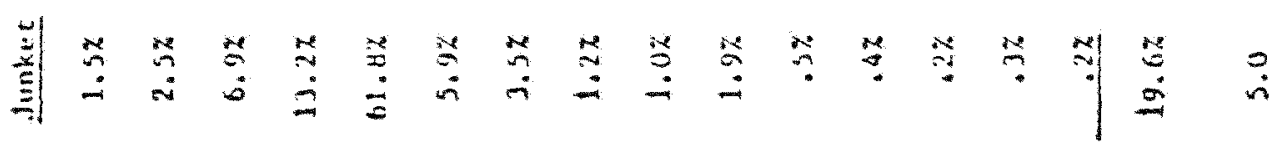

$\rightarrow$

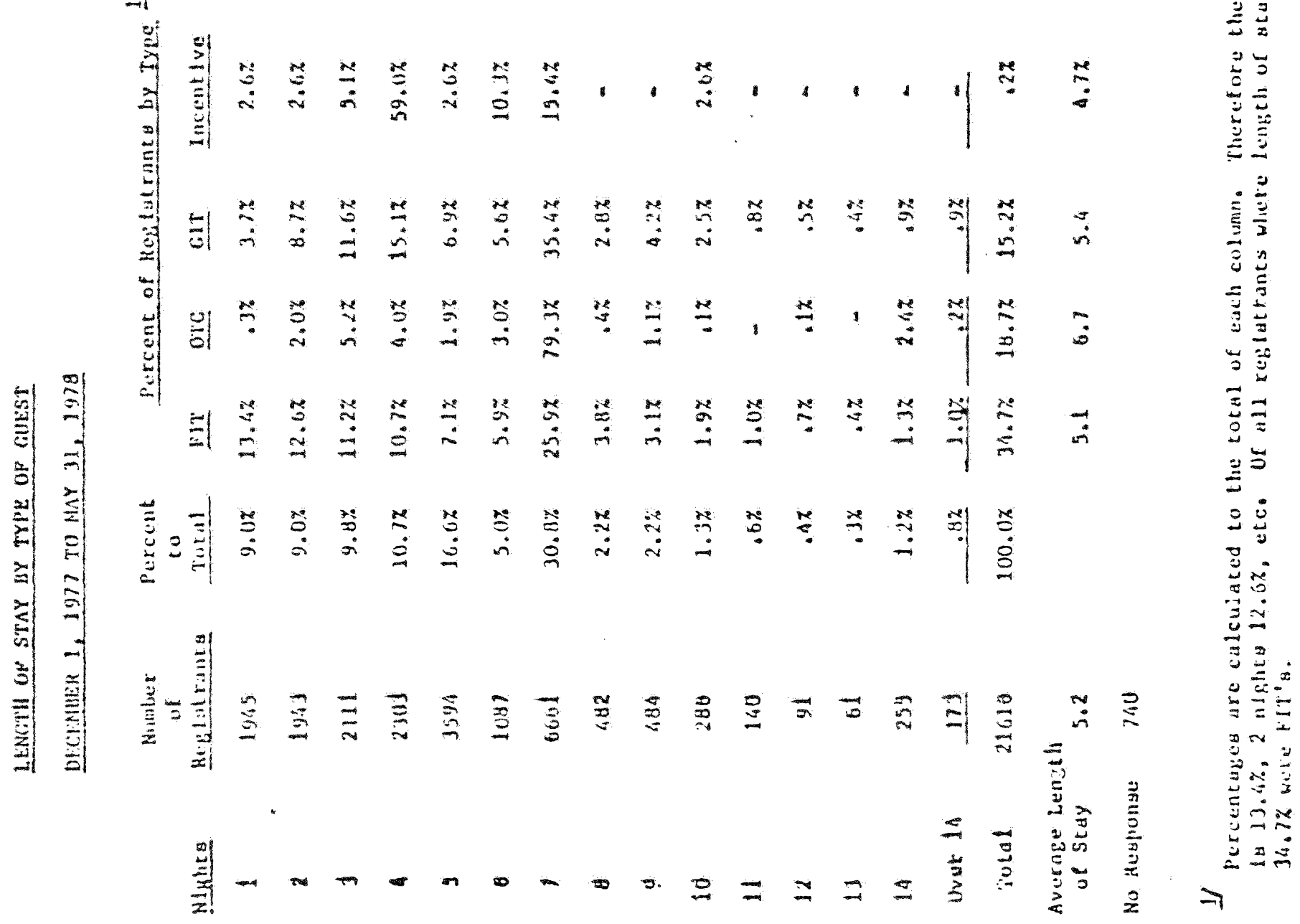




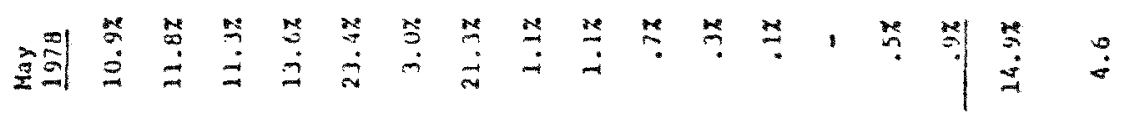

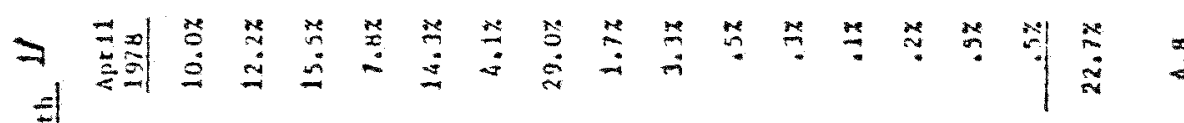
章

产焉

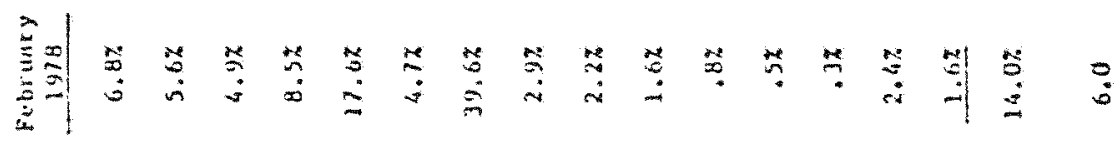

包总

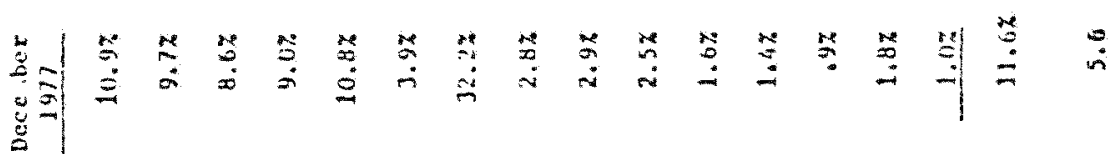

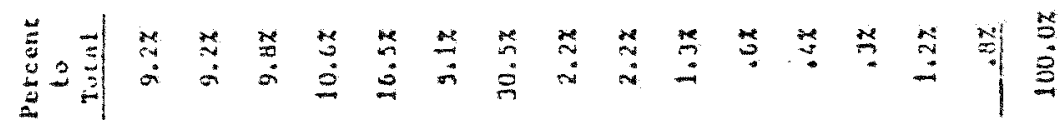

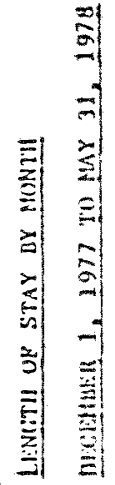

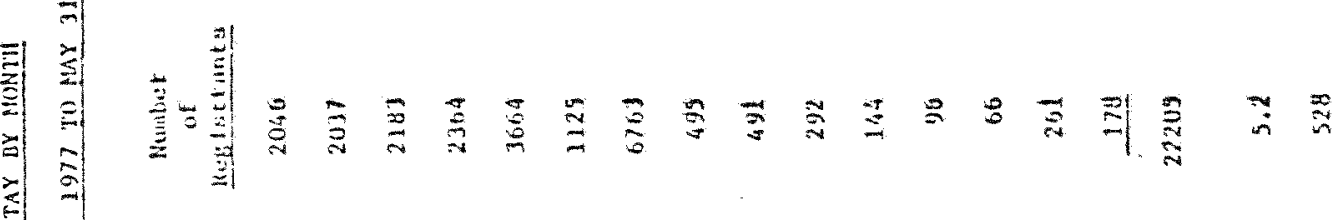

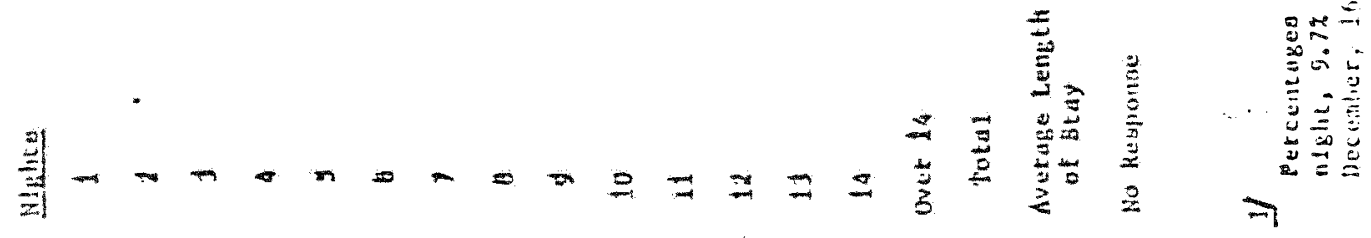


1. Number of Adults per Party: 14

The average number of adults per party and the percentages of registrants traveling in various party sizes are given by guest type and month in Table 4.25 and Table 4.26 on the following pages.

${ }^{14}$ Ibid., pp. 44-47. 


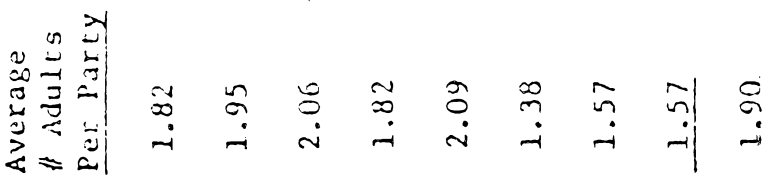

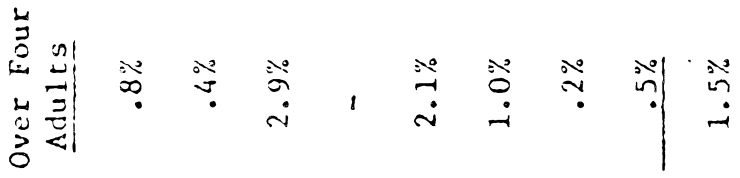

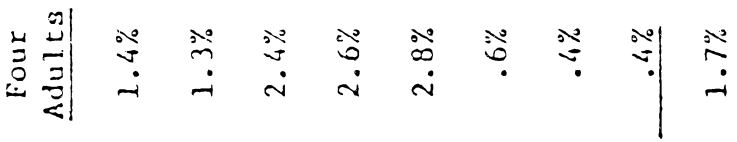

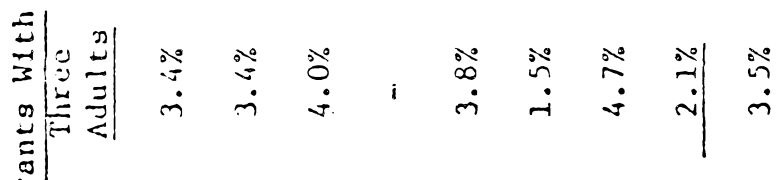

क्ष.

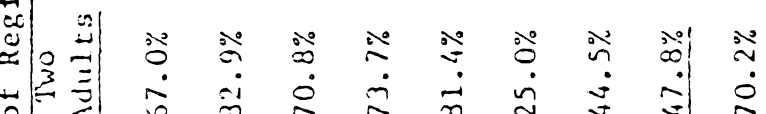

虫

岂

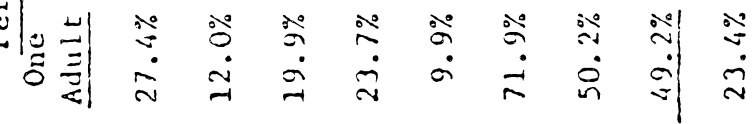

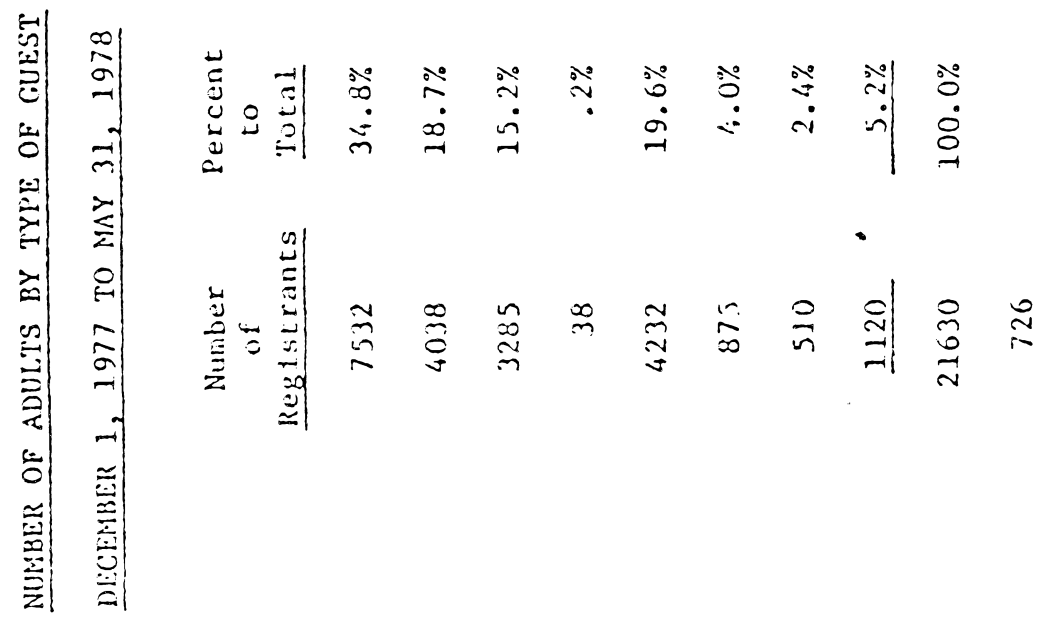

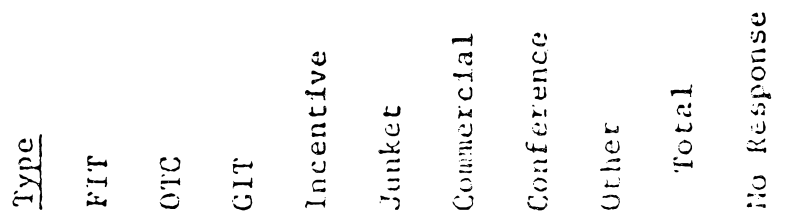


Table 4.26

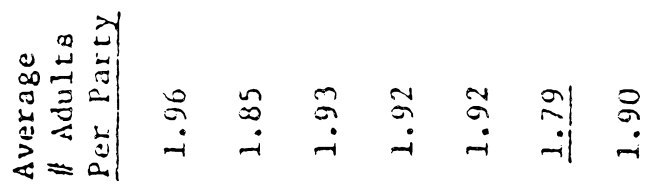

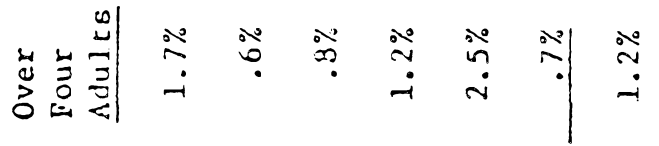

当热

尝

告

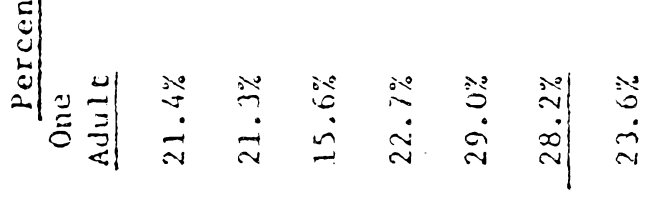

|

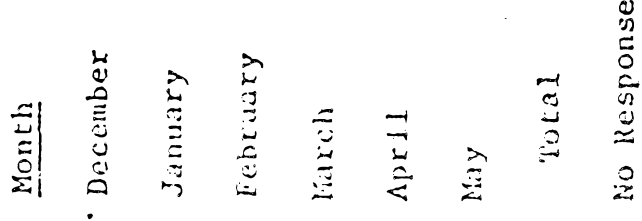


The average number of adults per party who stayed in Aruba during the six-month period was 1.9 persons. As indicated in Table 4.25 , this varied by type of guest. Over two out of every three FIT parties traveled with 2 adults, although $27.4 \%$ of this group had only one adult. Approximately $99.2 \%$ of FIT parties traveled with 4 or fewer adults.

Among the registrants traveling on group tours, again, 2 adults was the most frequent party size. For OTC travelers, $82.9 \%$ had 2 adults while $12.0 \%$ traveled alone; among GIT parties, $70.8 \%$ had 2 adults and $19.9 \%$ had one adult. As for junkets, $81.4 \%$ traveled in pairs while $9.9 \%$ traveled alone. However, junket parties were occasionally larger, with $3.8 \%$ traveling with 3 adults, $2.8 \%$ with 4 adults and $2.1 \%$ with more than 4 adults.

Number of adults in party was lower for the other types of guests. Commercial travelers averaged only 1.38 persons since the majority of business guests traveled alone. Conference travelers averaged 1.57 adults, with the majority of parties being 1 or 2 adults.

Average party size did not appear to vary to any extent by month as Table 4.24 illustrates. Average number of adults ranged from a low of 1.85 persons in January to a high of 1.96 persons in December. In February, parties of 2 adults were more frequent than in any other month. 
2. Number of Children per Party : ${ }^{15}$

Although most registrants during the six-month period traveled with adults only, some parties brought children. Parties with children and numbers of children per party are given by guest type and month in Table 4.27 and Table 4.28 on the following pages.

15 Ibid. , pp. 48-51. 


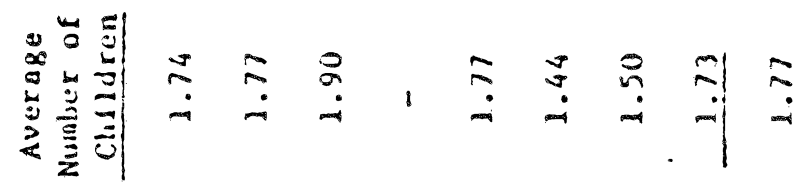

F)

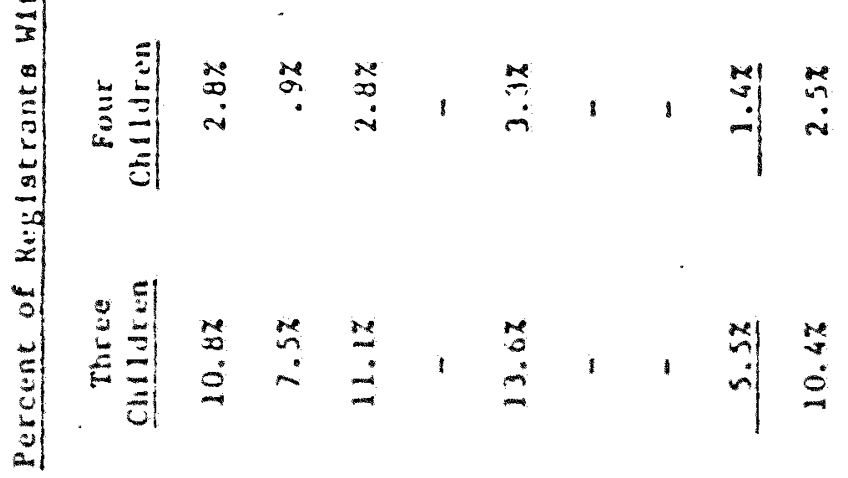

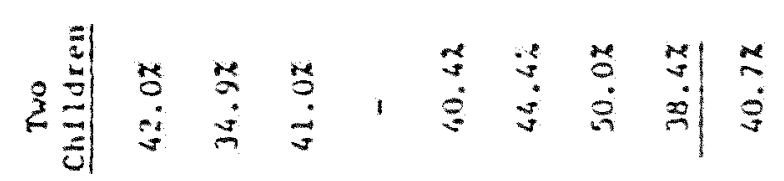

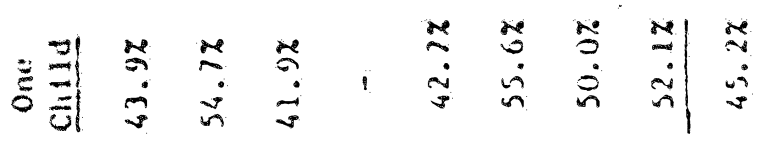

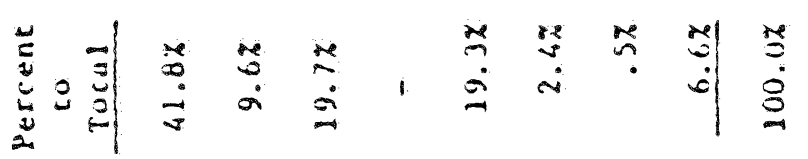

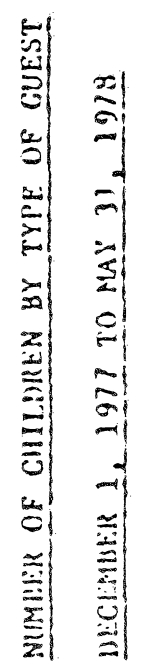

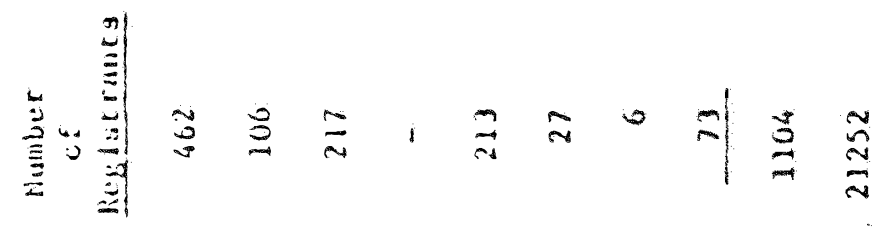

$w$

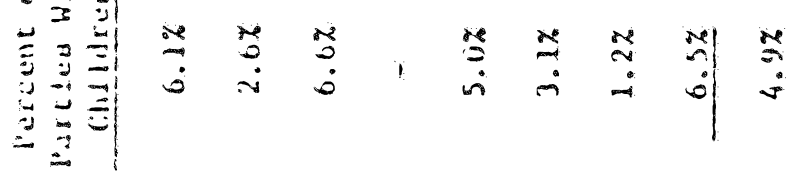

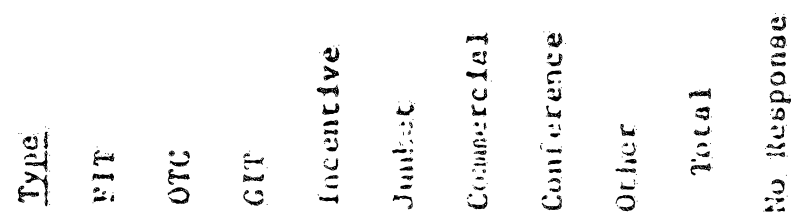




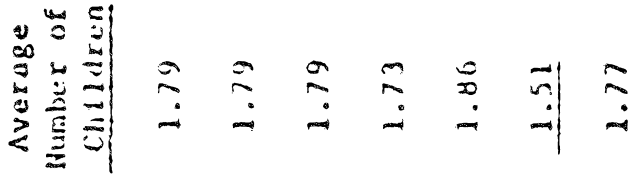

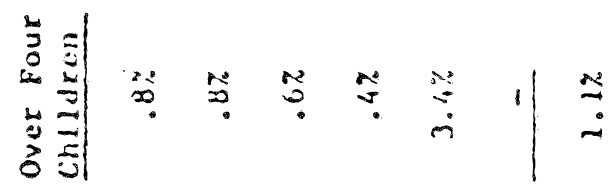

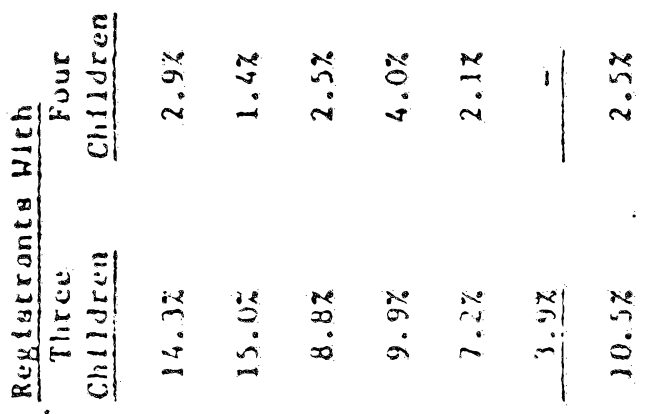

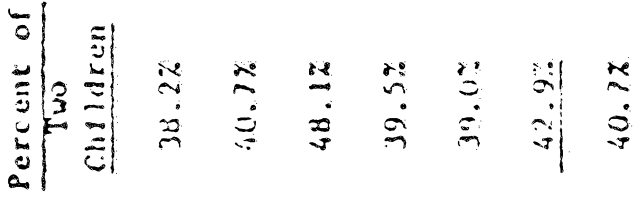

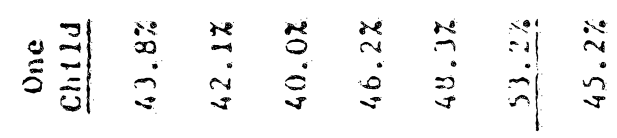

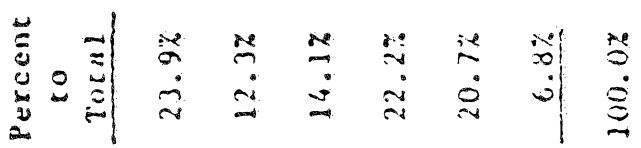

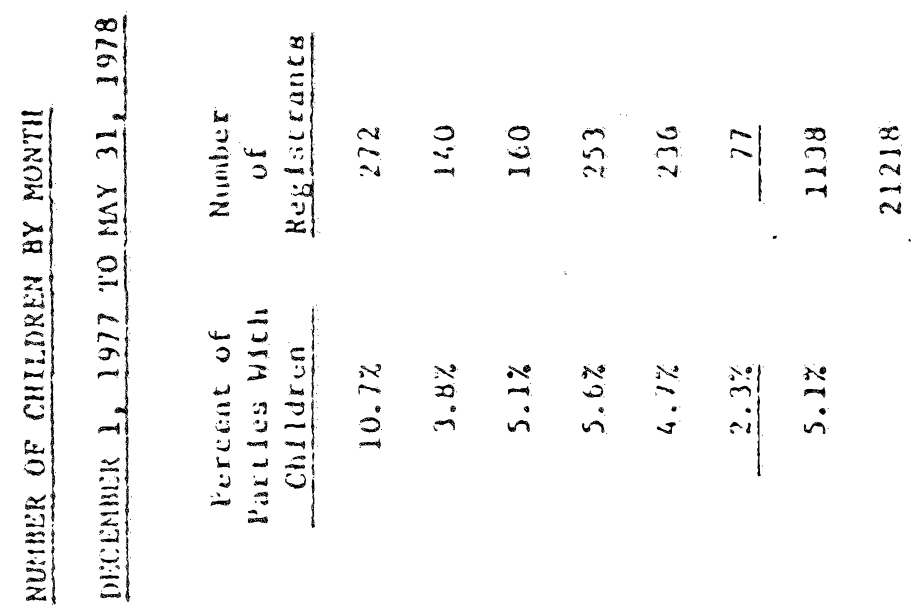

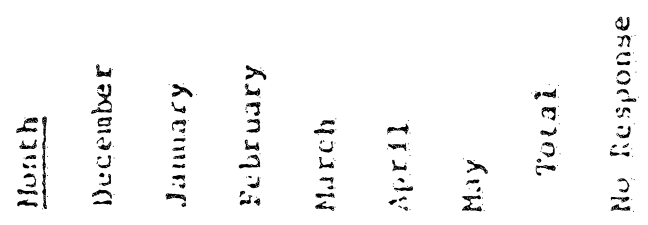


Only $5.10^{16}$ of all parties brought children, and of those parties, the average number of children was 1.77 . The percent of total registrants bringing one child was $45.2 \%$ while those bringing two children was $40.7 \%$. Parties with three children represented $10.4 \%$ of the registrants, $2.5 \%$ of the parties had four children and only $1.2 \%$ brought over four children.

Of those parties bringing children, more were FIT guests (some $41.8 \%$ ) than any other group. For the sixmonth period being analyzed, it is apparent that Aruba was not a family destination, but when children do come, they are more likely to accompany FIT, GIT or Junket guests than OTC, commercial or conference registrants. 
3. Spending Patterns of Registrants ${ }^{17}$

The spending patterns of registrants are reflected in their average daily expenditures for rooms and other charges to the room bill while staying in the hotel. These spending patterns, however, do not reflect what the guest may have spent in cash or credit cards, either in or outside of the hotel. Also, these expenditures do not include any wagers made in the casino.

a. Daily room rate paid. Daily room rates paid by type of guest and month are given in Table 4.29 and Table 4.30 on the following pages.

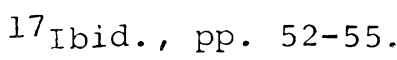


Table 4.29

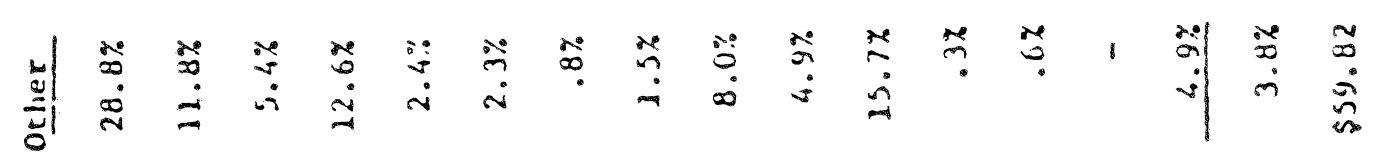

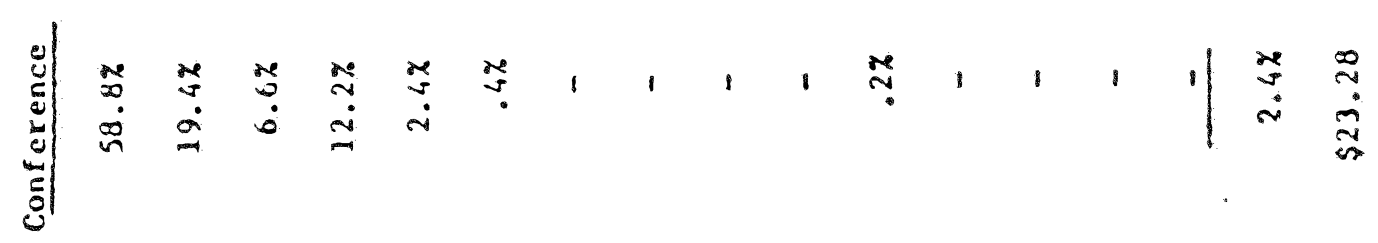

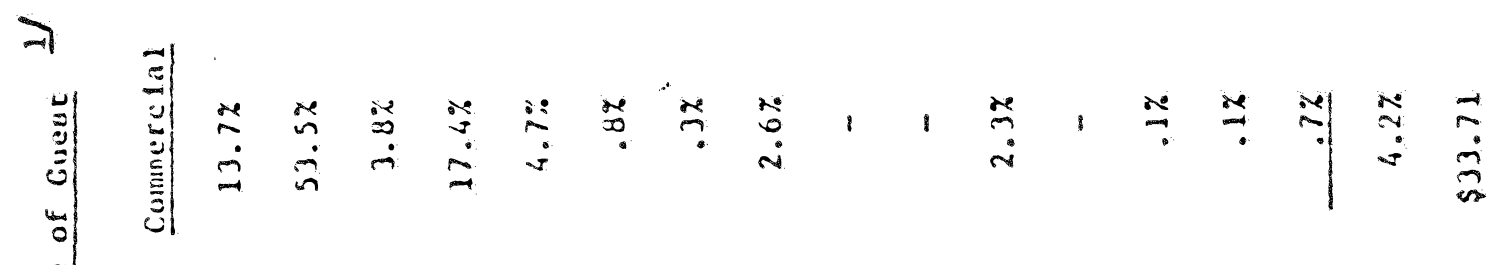

章

年

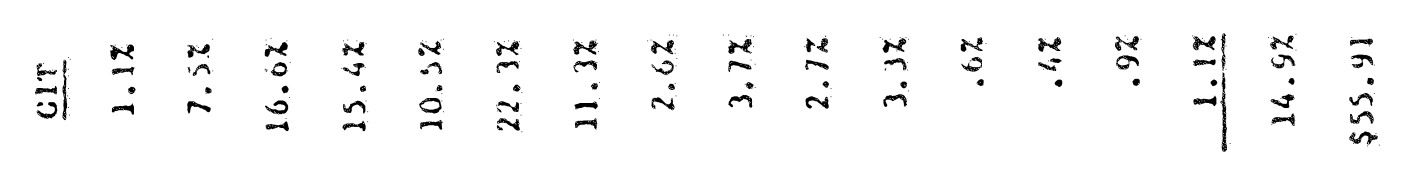

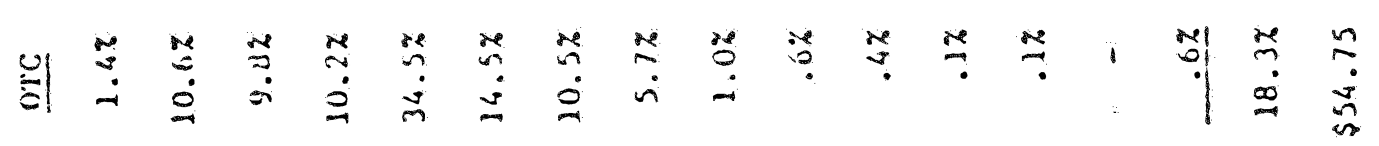

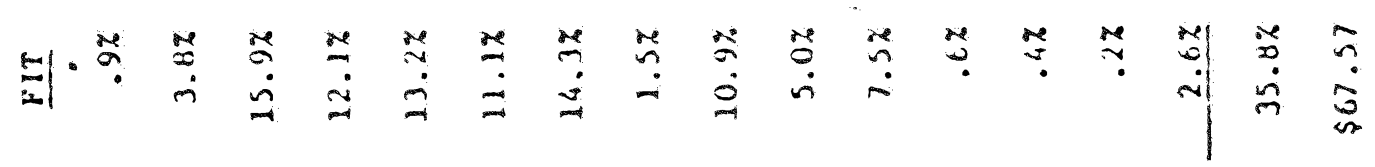

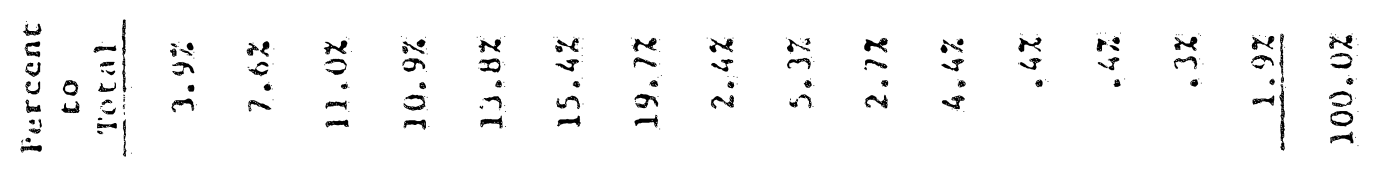

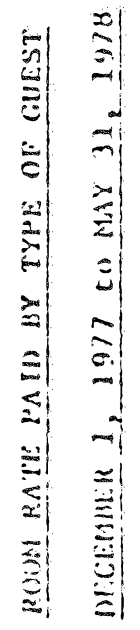

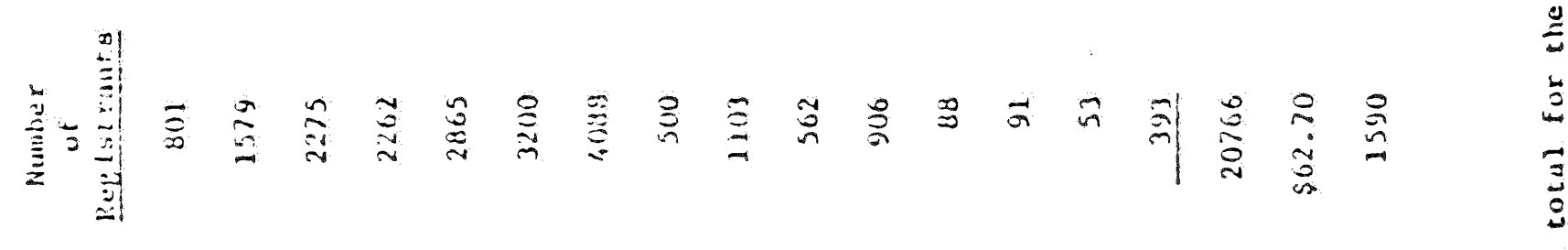

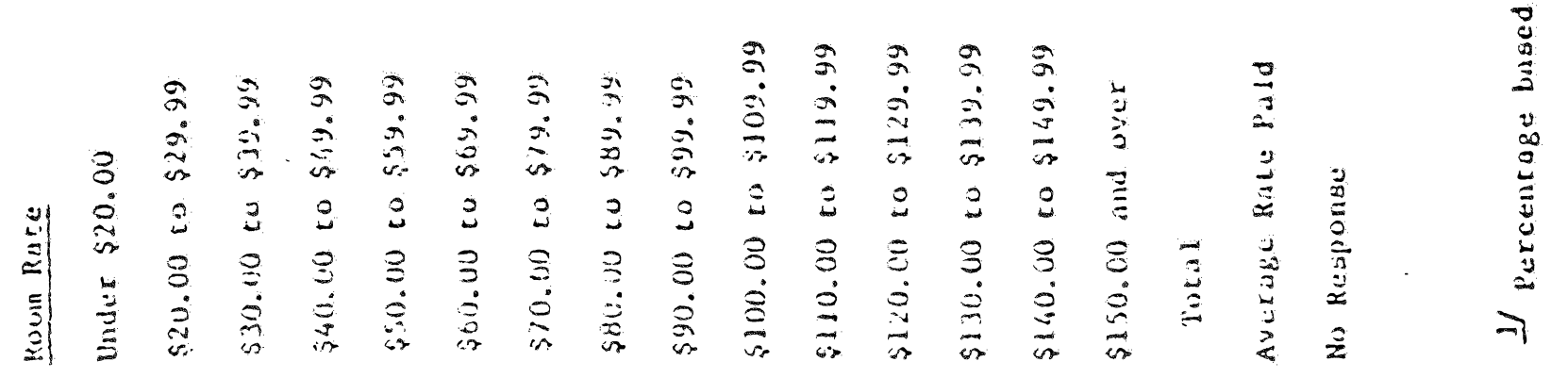




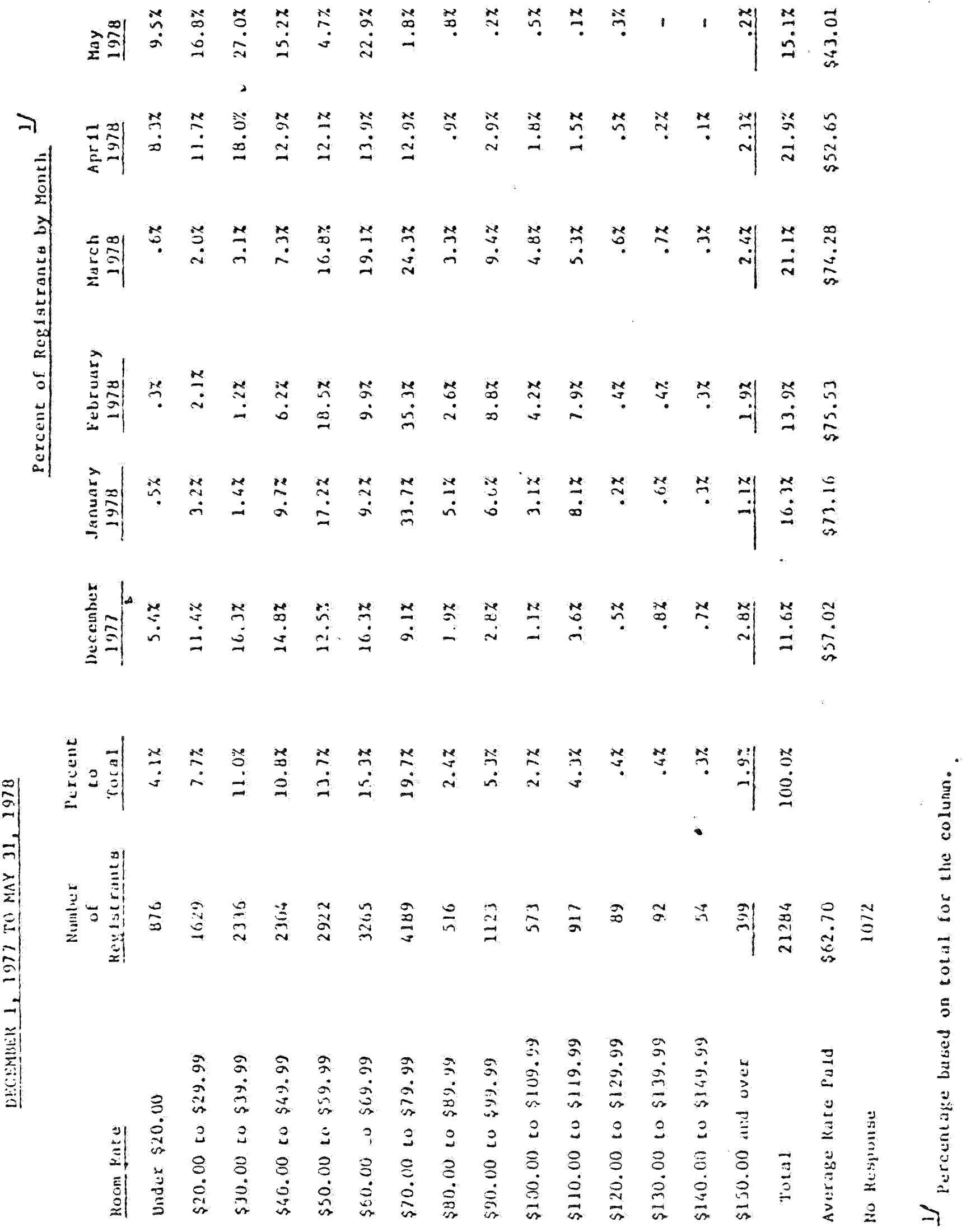


The average daily room rate paid by all registrants was $\$ 62.70 .18$ However, room rates paid ranged from under $\$ 20.00$ to over $\$ 150.00$. Of all registrants $19.7 \%$ paid rates from $\$ 70.00$ to $\$ 79.99,15.3 \%$ paid from $\$ 60.00$ to $\$ 69.99,13.7 \%$ paid from $\$ 50.00$ to $\$ 59.99,10.8 \%$ paid from $\$ 40.00$ to 49.99 and $11.0 \%$ paid from $\$ 30.00$ to $\$ 39.99$.

Room rates varied by type of guest. FIT guests paid an average of $\$ 67.57$, OTC guests paid $\$ 54.75$, GIT guests paid $\$ 55.91$ and Junket guests paid $\$ 74.11$. Conference guests were the lowest paying group at $\$ 23.28$, while commerical travelers paid an average of $\$ 33.71$.

Average room rate also varied by month as indicated in Table 4.30. The average room rate paid in December was $\$ 57.02$. Then during the heavy demand months the aveerage rate increased to $\$ 73.16$ in January, peaked in February at $\$ 75.53$ and declined slightly in March to $\$ 74.28$. With high winter season rates still being charged through the middle of April, the average held to $\$ 52.65$.

4. Stay plan of registrants 19 when a guest selects a hotel in Aruba, he or she has a wide range of stayplans from which to choose. There are twelve popular plans which are available at most hotels,

${ }^{18}$ Data and percentages from Table 4.30 . 19 Ibid., pp. 61-68. 
including six standard plans offered throughout the year, and six additional plans which were recently introduced as special promotional packages. The first six, which are widely available and need little explanation, are:

- Continental Plan (CP) which includes breakfast only, with the room.

- European Plan (EP) where no meals are included.

- Modified American Plan (MAP) which provides two meals with the room.

- Modified American Plan Junket (MAPJUNK) which is available for casino junkets and includes two meals.

- Full American Plan (FAP) where all meals are included with the room.

- Full American Plan Junket (FAPJUNK) which is available for casino junkets and includes all meals.

The remaining six plans are somewhat unique and are offered by some of the hotels during certain times of the year. These include:

- Free Spree European Plan (FSEP) - programs jointly promoted by certain airlines and participating hotels that provide an allinclusive tour package, excluding meals.

- Free Spree Modified American Plan (FSMAP)programs jointly promoted by certain airlines and participating hotels that provide an all-inclusive tour package, including two meals per day.

- Inter-Island Tour Plan (ISLE) - special allinclusive tour packages that include trips to Aruba, Curacao and Bonaire, including various special features. 
- European Tour Plan (EURO) - all-inclusive tour packages aimed specifically at promoting increased travel from European markets.

- Two-fers (TWO) - special programs featuring various package components on a "two-forthe-price-of-one" arrangement.

- Honeymoon (HONEY) - all inclusive tour package combining a variety of features of plans previously described but offered exclusively to newlyweds.

The descriptions of these latter six plans are only general, and specific offerings contained within particular plans will vary from one hotel to another. Also, these plans may only be offered on a selective basis by some hotels and may not be offered at all at others. Based on results received, only a few of these plans (62) were actually sold between December and May. However, due to the recent introduction of these plans, it is premature to judge whether they have been successful or not. Therefore, the entire list of stay plans have been included in Table 4.31 and Table 4.32 on the following pages to provide a basic for future comparisons of the respective popularity among various stay plan categories. 
Table 4.31

苞苛

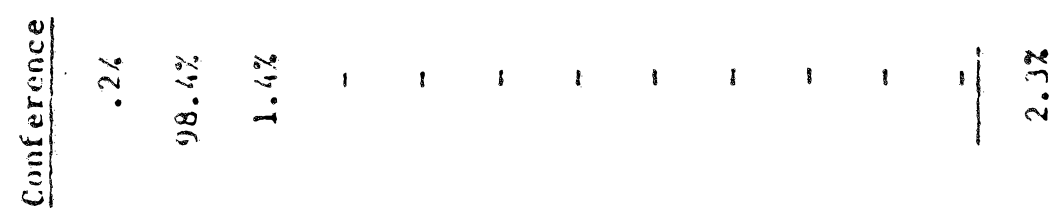

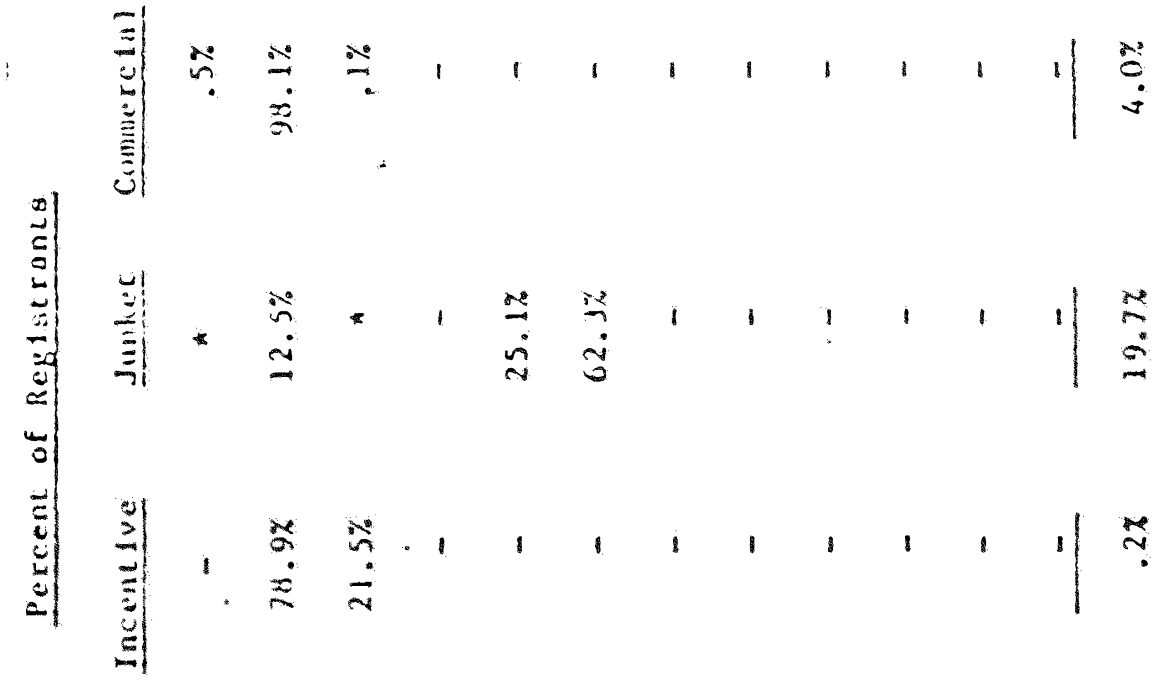

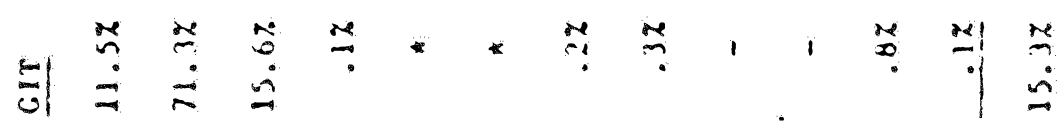

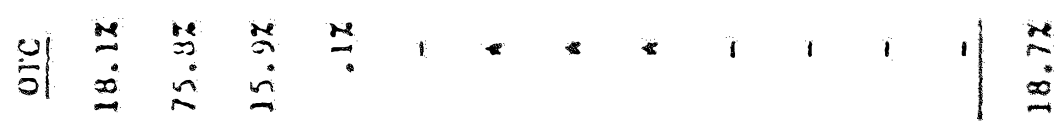

ப)

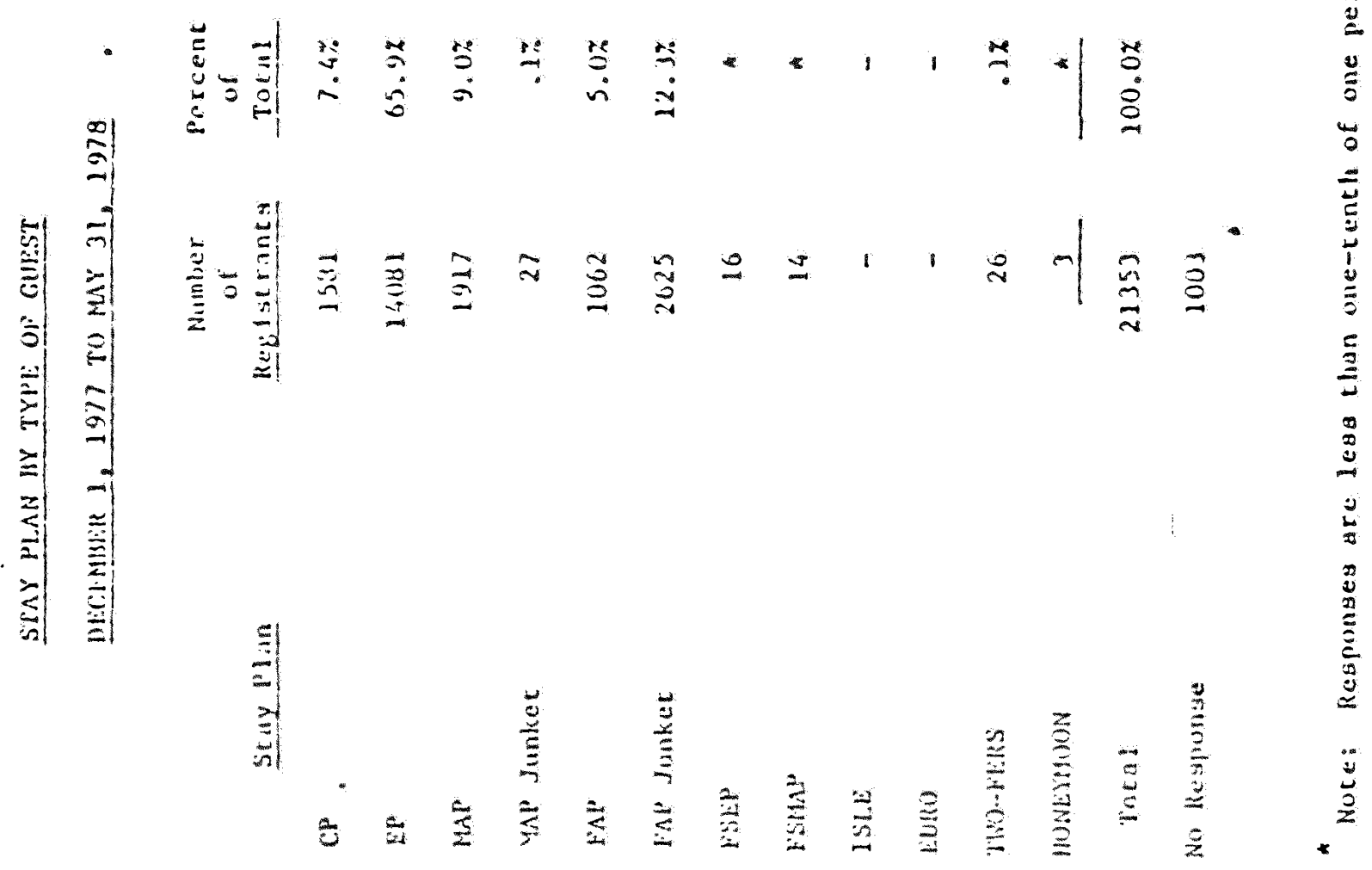




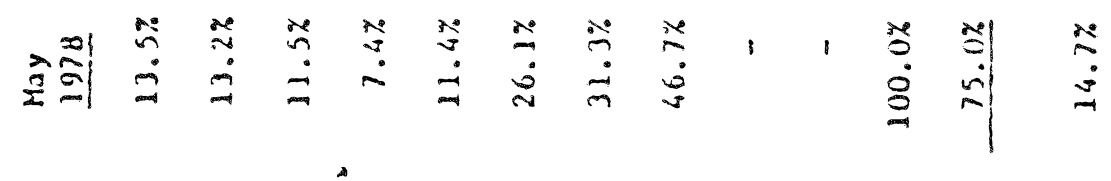

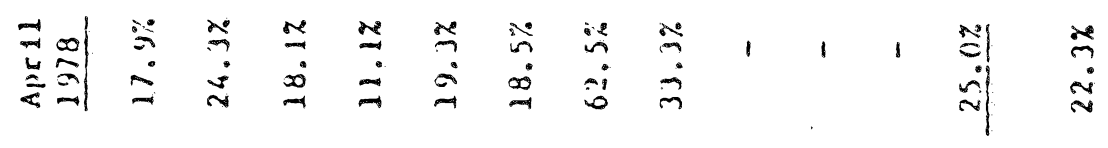

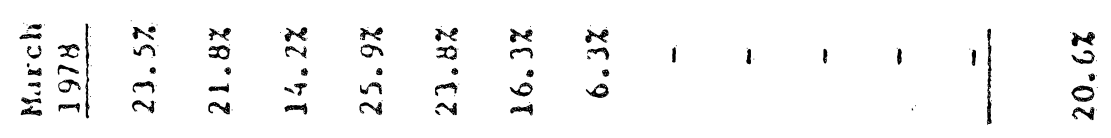

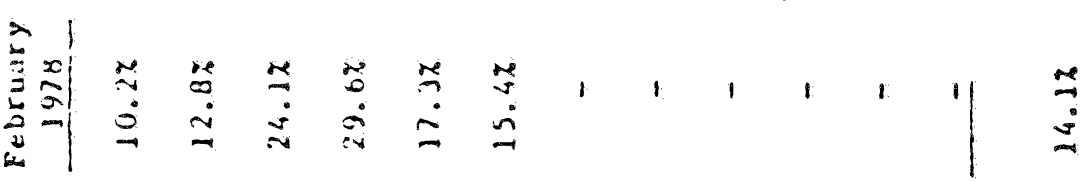

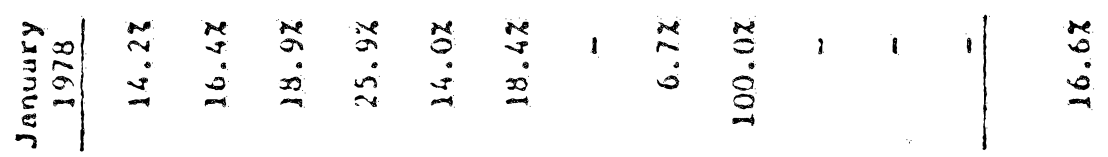

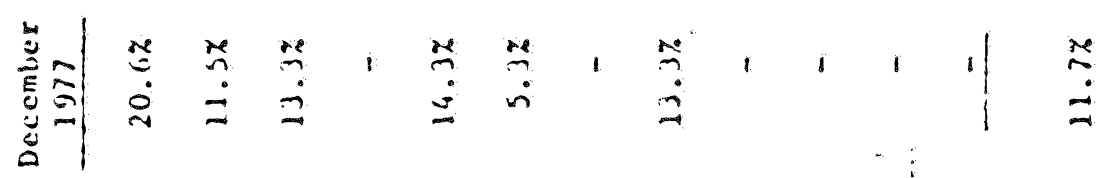

崖

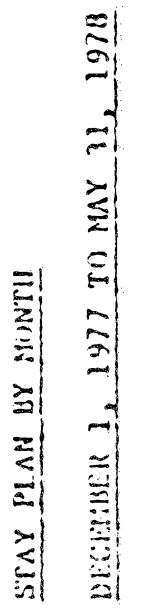

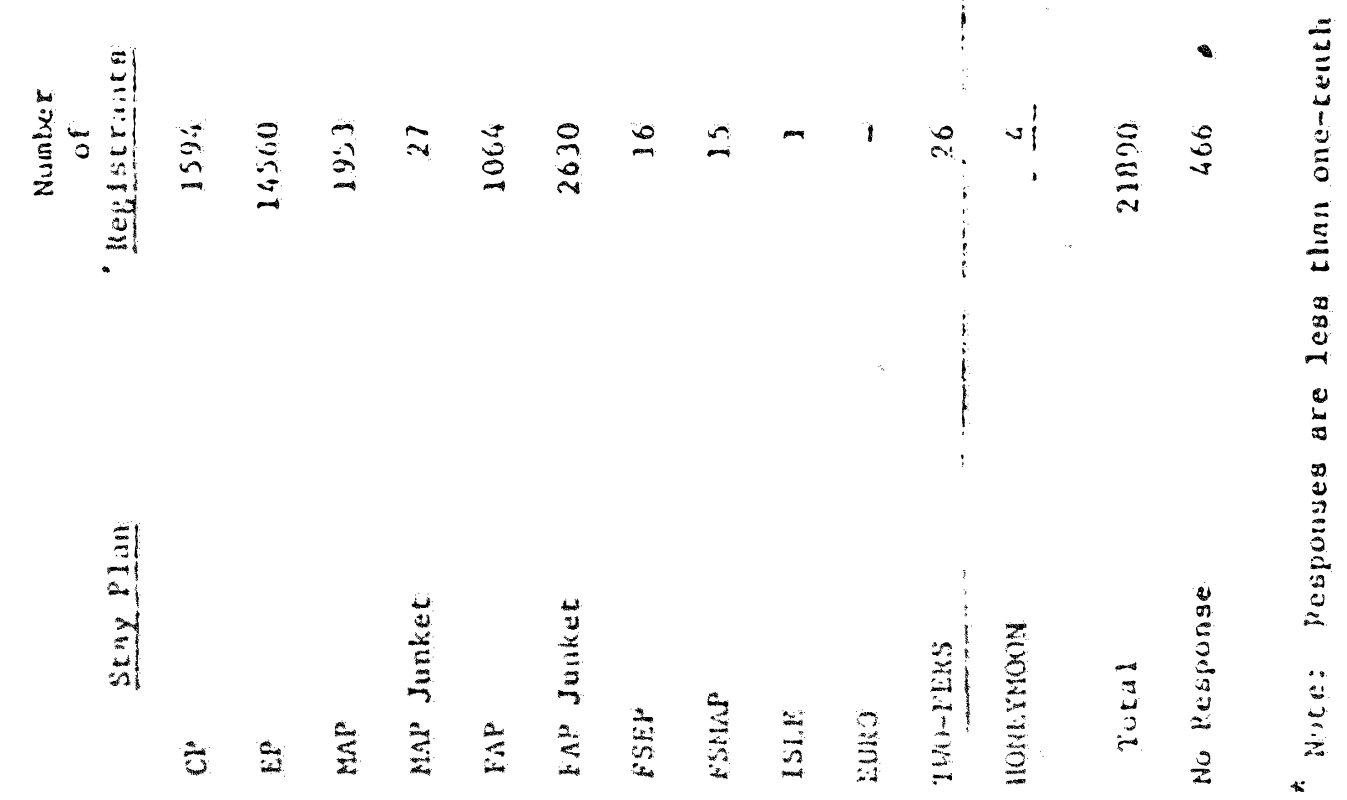


As indicated in Table 4.31 between December, 1977 and May 31, 1978 the most widely used stay plan was EP, with $69.9 \% 20$ of total registrants on that plan. Other popular stay plans included FAP Junket (12.3\%), MAP (9.0\%), CP (7.4\%) and FAP (5.0\%). The remaining categories of stay plans attracted fewer than one-tenth of one percent of total registrants during the period analyzed.

The choice of stay plan also varied by type of guest. With the exception of Junket travelers, the most frequently selected stay plan among the remaining categories of guests was the European Plan (EP). EP was picked by $78.8 \%$ of the FIT visitors, $75.8 \%$ of OTC travelers, 71.3\% of the GIT groups and $78.9 \%$ of those registrants classified as Incentive Travelers. EP dominated nearly all commercial and conference travelers as well, with $98.1 \%$ and $98.4 \%$ of those respective groups choosing that stay plan.

The Continental Plan and regular Modified American Plan were the second or third choices by nearly all of the remaining registrants among these same guest categories. However, percentage distributions were relatively low, with fewer than $20 \%$ of guest registrants selecting either of these stay plans.

20 percentages of frequency distributions of stay plan by month of arrival (Table 4.32) are marginally different due to slightly higher response rate. 
Junket travelers most frequently selected either FAP Junket (62.3\%) or regular FAP (25.1\% stay plans). In addition, 12.5\% of this group chose EP while fewer than onetenth of one percent selected CP or MAP stay plans.

Some variations in stay plans as selected by month of arrival were also evident. Nearly twice the number of EP plans were sold during March and April than were sold during any other of the other four months being analyzed. Of the 14,560 registrants who picked EP, 24.3\% arrived in April; 21.8\% arrived in March; 16.4\% arrived in January; 13.2\% came in May; $12.8 \%$ came in February; and 11.5 came in December.

The remaining stay plans were less frequently taken by guests, but among them the FAP Junkets were more popular during December, a fairly constant number of FAP junkets were sold during the other months as well. The number of CP packages sold varied from month to month, although the percentage of total registrants using $\mathrm{CP}$ was highest in December and March.

MAP Packages were more popular among registrants from December through February than from March through May. FAP, although a moderately used plan, remained fairly constant as a percent of registrants throughout the period.

All other stay plans, including FSEP, FSMAP, ISLE, EURO, TWO-FERS, and Honeymoon, were generally not promoted during the peak season period. Therefore, as mentioned previously, these six categories did not account for a 
material number of the total packages sold. However, it was evident that from mid-April through the end of May, some limited demand for several of these stay plan categories arose. However, as of the analyses only one InterIsland Tour package and no European Tour package had been sold to date.

\section{Economic constraints}

Economic factors are the most active set of limitations or obstacles to the future development of international tourism. The government is persistently pursuing the policy that the answer in developing markets is not pumping money into promotion until these geographic origins are known. Robinson's, Inc. of Orlando, Florida had been contracted to study the markets, but until now no extra credit appears on the budget in order to assess the promoting in the areas of its findings.

While the world was suffering from recession and energy crisis, Aruba was able to show steady growth in visitors even when fares were skyrocketing abnormally. The fuel embargo hit the major source of income of Aruba. Lago Oil \& Transport Company (EXXON), one of the world's largest refineries, had to cut down production by $40 \%$ and coupled with the Carter's Administration of oil import reduction, the refinery was operating at the beginning of 1978 at a 50\% capacity. This eventually will result in approximately $\$ 20$ million decrease in the island's GNP. 
With the independence of the Netherlands Antilles in sight considerable problems are encountered in securing capital investments from potential investors in any industry; the European Common Market and Holland. Holland approved only half of the required economic assistance to Aruba of NAf 200 million required for the next 10 years in early 1978. 
CHAPTER V

THE SOCIAL IMPACT

The world is changing. We live in a world in which change is the rule rather than the exception. Change is usually costly. Not only does change disrupt the existing life pattern of a society but even the existing social values and mores. Very few innovations can be hung to the existing social structure; most innovations need some adjustment to the existing society. After a prolonged period of discussion, Canada has switched to the metric system of measure. Britain's change to the decimal system brought more problems than just the people having a new monetary system. I

As an aspect of culture, tourism is theoretically subject to the control by man. This cannot, however, appear to be decreasing as tourism becomes more international. The modern man in a developing society is faced with decisions that are far more complex than those faced in the past. The many rapid social forces that are impinging on him are hard for him to grasp, leave alone absorb. The funniest part of it is, they are mostly not

IDr. R.J. Sethna, The Social Impact of Tourism, (Caribbean Tourism Research Centre, 1971), p.4. 
his creations. 2

Undoubtedly, Aruba had some changes in its social environment the last twenty years. One can argue the point that these changes came along due to the International Tourism Industry, because Aruba had quite some changes in its economic development before the tourism industry had opened the new economic era in the history of the island.

As this study is prepared to analyze the social impact of the International Tourism on Aruba, only this impact will be discussed in this section of the study. Many social leaders have been interviewed by the researcher to stress the implications of the impact caused by the International Tourism. With these implications the researcher will not approve or disapprove, or propose any changes in the Aruban society. These implications will be stated merely to analyze the impact which undoubtly exist if we read Erik Cohen and Dr. R.J. Sethna. ${ }^{3}$

To describe the social impact of tourism as all good or all bad is not telling the whole truth; it is like saying one can pull a cart on one wheel, or use a coin with one side. 4

In the social effects peculiar to tourism the chief factor is the very presence of visitors in the country.

${ }^{3}$ See page 17 and 18 of the Chapter Review of The Literature for explanation.

${ }^{4}$ Dr. R.J. Sethna, The Social Impact of Tourism, (Caribbean Tourism Research Centre, 1971), p.1. 
The impact of their sheer numbers (measured by arrivals or bed-nights) varies according to the size of the population and of the courtry or area actually visited. While some areas ranking as important tourism destinations receive tourist numbering no more than 1 or 2 percent of their population, a few others receive as many as 5 to 10 times the number of their inhabitants. Given the geographical concentration of most countries' tourism industries, those with an apparently low ratio between tourists and population may have areas where the number of tourists in relation to locals is actually much higher, which is the case in Aruba, if we compare the arrivals of visitors of the last ten years with a population of approximately 62,000

On the positive side, it is argued that, apart from tourism being generally beneficial in improving mutual understanding, the contact involved contributes socially to economic development by generally encouraging "development-mindeness." 5 This is not, of course, easily evaluated; and any evaluation is likely to be influenced by the view taken about what is the correct path to development. The least that can be said is that there is, indeed, propagation of the notion of economic change. The growth of the tourist

5 Adapted from, The Impact on International Tourism on the Economic Development of the Developing Countries, (International Union of official Travel organization, World Tourism Organization, Geneva 1975), p.33. 
industry, like that of other sectors, helps to produce increased income and employment opportunities. And the improved infrastructure, equipment and services provided by the industry's growth may be enjoyed by the population at large, to a greater extent than is often the case for alternative forms of development.

On the other hand some social disadvantages may emanate from tourism. The "demonstration effect" that may set standards for desirable change can also operate to encourage other changes that are regarded as more or less undesirable. The presence of tourists in large numbers tends to encourage consumption patterns that are often inappropriate for the population as a whole, since they reflect the tastes of visitors with income levels higher than those prevailing in the host country. And some services provided for tourists are demanded for, but cannot possibly be supplied to, the entire population. It is chiefly those most closely involved in the tourism industry who are led to have such expectations, it is argued; and they may tend, by their income levels, expectations and life style, to accentuate social cleavages in the country. In more general terms, it has been argued that tourism has, in the case of many developing countries, helped to undermine social standards, through the behavior of tourists and through the demands that are imposed by tourist trade. 6 


\section{A. Implications of Impact}

This section of the chapter will show responses of different social leaders interviewed by researcher. Interviews were held with: Union leader, political leader, Director of the Aruban Hotel and Restaurant Association, Director of the Aruba Tourist Bureau, religious leaders, Directors of two local newspapers, previous Director of Aruba Tourist Bureau, a person who had been involved in many of the changes which occured during the developments in the tourism industry, member of the local Chamber of Commerce and last but not least, families involved in the evolution of the industry.

Researcher is aware that opinions of a group of people are not the opinions of the entire population. The following are the general implications:

The tourism impact as an advantage on the Aruban society:

- Employment in tourism industry (direct or indirect) for a vast amount of people after the automation of the oil refinery.

- The mass movement of foreign people to Aruba presented a leisure lifestyle to the Aruban people.

- Stimulation of ambitions of hospitality workers; they also want to reach a certain goal in life.

- Exposure of foreigners to local people.

- Achieving the world wide recognition that Arubans are seen as having a great deal of hospitality. 
- Education has been broadened to include courses about tourism and the hospitality industry.

- Developing and improving the awareness that working in the tourist industry is not a menial task.

- Creation of entertainment centers open to the general public. 7

The tourism impact as a disadvantage on the Aruban society:

- Inappropriate patterns of expenditure and behavior of locals.

- Standard of living has sky-rocketed since the introduction of foreign tourism from countries with a high standard of living. McIntosh explains this as follows: 8

- . International travel largely emanates from countries with a comparatively high standard of living with high rates of economic growth, with social systems where inequality of incomes are declining and the bulk of the population is urbanized. In addition, these international travelers come from countries where large-scale industry and commerce comprise the foundations of the economy and where the conmunications and information environment is dominated by the mass media. The international market is largely made up of middle income people including the more prosperous minority of the working class, who normally live in large cities and earn their living in managerial, professional, white-collar supervisory and skilled occupations.

7 During the development of the oil industry there existed entertainments but these were private.

${ }^{8}$ R.W. McIntosh. Tourism: Principles, Practices, Philosophies, (Gird, Inc., Columbus, Ohio 1972), p.29. 
Probably the most pronounced effects of this phenomenon are noted when visitors from North America or Western Europe travel in emerging countries having a primitive culture or a culture which characterized by low (economic) standard of living and unsophisticated population.

- International Tourism has increased the crime rate, (See Table 5.1) drugs trafficking.

- The divorce rate (See Table 5.2) has increased, especially among the hotel employees.

- Another problem that has been noticed lately is the increase of prostitution by the local youth. This problem, if not attacked in time, will cause serious problems with consequences for the tourism industry and the society in general.

- Problems in families where parents and children work in the hospitality sector. The conformance to employment regulation can result in drastic change in mode of living by those persons so employed or may not be desirable from the employee's point of view.

- Resentment by local people towards the tourists because the tourists are taking away all of the nice beaches. 


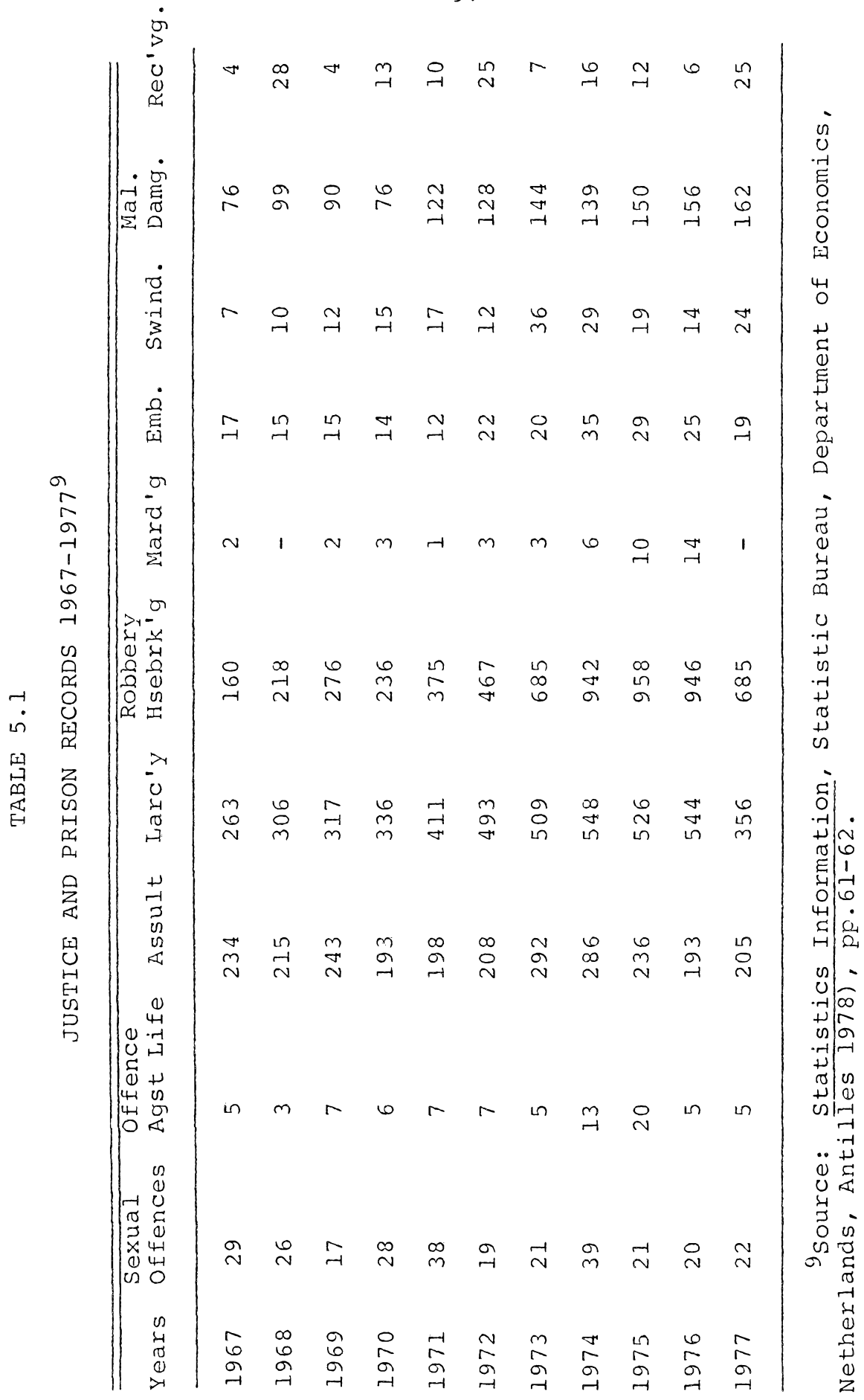


TABLE 5.2

REGISTERED DIVORCES ON ARUBA 1967-197710

\begin{tabular}{lcc}
\hline Years & Divorces & Total Population \\
\hline 1967 & 55 & 59,020 \\
1968 & 65 & 59,231 \\
1969 & 69 & 59,813 \\
1970 & 69 & 60,811 \\
1971 & 106 & 60,293 \\
1972 & 92 & 61,293 \\
1973 & 97 & 61,711 \\
1974 & 110 & 61,788 \\
1975 & 118 & 62,982 \\
1976 & 122 & 62,288 \\
1977 & 102 & 62,755 \\
\hline
\end{tabular}

From the above table one can observe the increase in divorces from 1967-1977. A 54\% increase if we take 1967 as the base year. It is arguable that this increase is because of the impact of tourism because earlier figures were impossible to obtain. But responses of interview with social leaders, previously mentioned, reflected that before the tourism industry hardly any divorce was heard of.

$$
10 \text { Ibid., p. } 5 .
$$


CHAPTER VI

THE FUTURE ROLE OF TOURISM

The world tourist movement has manifested itself in the last two decades as one of the fastest growing items of world trade as well as a dynamic and ever progressing industry. Yet, the ratio of increase has been far from even during this period due to fluctuating trends of various inducing and accelerating factors of international tourism. On the whole, one can safely say that since 1950 an overall average of just below 10\% increase annually always applied to tourism. This brought international tourism up from 25 million tourist arrivals in 1950 to about 215 million in 1973.1

The long-term forecasts released by IUOTO some three years ago made it clear that by 1980 international tourism would reach about 200 million tourist arrivals as against 150 million in 1970. As a low estimate, the number of tourist arrivals will be around 250 million in 1980 out of which Europe will receive 180 million representing $72 \%$ of the world tourist traffic. 2

${ }^{1}$ Salah Wahab, Tourism Management, (Tourin, Italy: Tourism International Press, 1975), p.169.

2 International Union of official Travel Organization. Pilot Study on Long-Term Forecast (Geneva, 1974). 
Such forecast is based on the following assumptions:

1. The world population based on the present world rate of increase, averaging more than $2 \%$ a year, may reach about 6.8 to 7 billion people in the year 2000 .

2. The European population is expected to rise to 792 million in 1985 and 886 in the year 2000. The North America population will likewise rise to about 430 million in 1985 and 578 million in the year $2000 .^{3}$

3. The GNP per capita in Europe will rise from an average of $\$ 1,970$ now to $\$ 2,870$ in 1985 , an increase of $145 \%$ and to over $\$ 5,000$ in the year 2000 , an increase of 253\%. The North American GNP per capita will increase from about $\$ 3,400$ now to about $\$ 4,330$ in 1985, an increase of $127 \%$ and to $\$ 6,250$ in the year 2000 , an increase of $183 \% .^{4}$

4. The "prosperity gap" will increase between the haves and the have-nots to reach 50.1 in the year 2000 unless the third world countries catch up much faster with the more advanced countries due to the pressing difficulties in the latter countries. And if this happens, the whole process of progress and development will certainly be checked.

$3_{\text {Kahn }}$ and weiner, The Year 2000, 1968, p.139. ${ }^{4}$ Ibid. 
5. Having regard to the IUOTo estimate the elasticity of world tourist expenditure (International and domestic) is $1: 2$ in relation to the variations of total income, the annual increase rate of tourist expenditure will be $5.7 \%$, which will raise tourists expenditure (domestic and international) to about \$86 billion in 1975 and \$151.5 billion in 1985 . 6. Technological progress is likely to accelerate and therefore means of transport should diversify and distances will be diminished through increased speed and better safety measures. Transport cost, however might still be an obstacle because of the steady increase in fuel prices.

It is due to all previous factors as well as others that the IUOTO has estimated that by 1980 there could be between 780 and 1050 million domestic and foreign tourist arrivals throughout the world, of which 250-280 million could be foreign tourists. 5

This encouraging estimate, which was conservative at the time it was made, might be strained by the supervening/acute economic and energy problems facing Europe at present. Various factors that might have a positive or negative influence on the tourist movement in the world at least in the short to medium term are political, institutional, economic, social, geographic and technical.

${ }^{5}$ International Union of Official Travel organization, Pilot Study on Long-Term Forecasts, (Geneva, 1974). 
They should be seriously taken into consideration when studying the future of tourism.

To most people in Aruba, tourism looks like a beautifully dressed-up shop window, with the draped or semi-nude figurines having miraculously strolled out of the glass case to swarm on the beaches, the town pavements, and through the city streets. But to those in the trade it is a different, nerve-racking exercise: how to market the product properly, sort out the right market, the proper clientele and, once formed, how to keep them right there as long as possible, nurse their interests in the country, and the people and keep their minds alert, up to the very last minute of their stay.

For we are dealing here with the most complex of industries, with its cause and finality rooted in the human heart. Beyond and above market studies, research reports, statistical interpretations, the core of the matter is that the raw material at our disposal is eventually human nature, with its changeable whims and moods, its vulnerability to fancy, fashion and change, social, economic or both.

Many then are the constraints facing the industry, especially in a developing country.

Since the industry is so important, with its occtopus-like tentacles reaching deep into many sectors of the life of a people and its government, the government, therefore, has to exercise its responsibilities to the full, 
determining the right tourist areas of development within the overall national policy and objectives, phase this development also in such a way as to ensure that it does not encroach upon all the other vital priorities of national development, upon other necessities, agriculture, industrial, social, etc. 6

Seeing the projections of many studies done by different tourism organizations for the 80s, one can safely assume that the international tourism will continue to grow. Aruba (an island in the Caribbean) certainly will enjoy the role of the host country for a vast amount of visitors. Presently the role of the international tourism upon the social economy of the island can be managed by the local authorities. But if we foresee a growing trend in the industry, drastic changes have to be made on the part of National Tourism Organization (Aruba Tourist Bureau). Presently the islands government operates directly in the tourism sector which is not suggested on an island where tourism is already fairly advanced and where the private sector is active in it. That's why it is preferrable to establish a tourist organization that functions as a professional body outside the government in order to play an optimum role in the industry in the near future. 7

\footnotetext{
${ }^{6}$ World Travel No. $140 \mathrm{Jan}$. -Feb. 1978, p. 26.

${ }^{7}$ In 1976 the Government of Aruba supported a commission to study such possibilities. The well known Estrada
} Rapport. 
This organization have to be strenghtened by representatives of various segments of the Aruban community to develop the future impact of the international tourism economically as well as socially. It is obvious that the government also will have its vital part in such an organization. If we quote McIntosh, he wrote the following about NTO's:

. Whatever the tasks that the National
tourism body is called upon to do, what is
essential is that it should have the full
powers necessary to carry them out. It
must, above all, have authority. It must
be able to present effectively the case for
tourism among the claims of other sectors
competing for government support and fin-
ance. In a situation where the imperatives
of tourism development infringe on those
of other sectors and there is a conflict of
interests, as in the location of a highway
or the priority to be given to a new airport,
the head of the tourism organization should
be listened to with as much respect as the
Ministers of public Works or Aviation.

It is essential also that it be technically competent and recognized as such. The wide range of functions developing upon it require a high degree of experience and professionalism and the caliber and prestige of the senior management of the National tourism organization can be important factors in the effectiveness with which the government puts through its tourism policy.

Finally, it is essential that the tourism office recognizes the limitations of its own mandate, however that may be defined, and maintains close and harmonious liaison with all the other interests that may be involved in tourism development. Three principal interests are concerned. The first is the national planning organization. In most countries there is regular provision for this liaison at the national level.

The second is liason with the other departments 
of government, partly as a matter of information and negotiation between different interests e.g., labor regulations, taxation, etc., and partly for the infrastructure and services needed for tourism development and which will normally fall to other departments to provide.

Thirdly, there must be the fullest co-operation with the private sector. This should be preparing its program in consultation with local and private interests. It sould continue by means of frequent and informal contact to ensure harmonious collaboration on the practical problems involved in making the program into a profitable business. 8

Future tourism has to be looked at from the viewpoint of what needs to be done rather than to sit back and "contemplate" what will happen.

Public authorities in both tourist generating and tourist receiving countries, having regard to the needs and conditions of their national economy, their social and cultural development and the protection of their environment, should take upon themselves the obligation to plan tourism expansion in the medium and longer terms. 9 such planning would mean to formalize action programmes wellsynchronized in time for the various tourist facilities and services as well as their national tourist demand.

Such planning should not only concentrate on tourist supply development but should go beyond to match development with already forecast demand which is expected to change. In this sense, a marketing approach should become the point of departure.

\footnotetext{
${ }^{8}$ R.W. McIntosh, Tourism, Principles, Practices, Philosophies (Columbus, Ohio: Grid, Ind., 1972), pp. 161-162.

${ }^{9}$ Salah Wahab, Tourism Management (Tourin, Italy: Tourism International Press, 1975), p.172.
} 
Wahab stresses the future role of tourism:

- . No matter what type of tourism organization be created in various countries, a common task would be to place tourism and recreation policies as top priorities in the lists of Government's responsibilities whether in advanced or developing countries.10 


\section{CHAPTER VII}

\section{SUMMARY AND CONCLUSIONS}

Aruba, an island in the Caribbean, with its beautiful beaches and its genuine hospitality has all the potential for large-scale development of its tourist industry. The Aruban Tourist Industry has grown rapidly after 1959, since the construction of the first luxurious hotel was begun by the Island Administration and as soon as they have finally resolved to throw out Aruba lures to attract tourists. Tourists areattracted to Aruba primarily from the United States, Canada, Venezuela and Columbia. The European market remains practically untouched. There may be many reasons why this market has not been explored. One reason might be that air fares to and accomodations on Aruba are still very highly priced. The tourist growth rate compares very favorably if we analyse the years 1959 to 1977. The steady growth of visitors has created an upward trend in the Aruban economy. Not only more accommodation facilities were needed to accommodate these visitors, but also many employment opportunities were created, not only directly in the hospitality fields but also in related fields. More money was pured into the economy through this significant tourism growth and at the same time the infrastructure has been improved, providing better accessibility to the island. 
The improvements in the infrastructure has benefited the visitor as well as the local population.

The hotels maintained an average of $75 \%$ occupancy rate throughout the years, generating millions of dollars and in so doing sustained the island economy. A rough estimate for the fiscal years 1973-1976 shows the flourishing tourist industry. Undoubtedly this mass movement of people not only created an impact on the economy of Aruba but also exercised its influence on the Aruban society. Many social leaders were content with the growth rate in the tourist industry but on the other side are regretting its negative impact on the society. Findings, mentioned by these leaders indicate an advantageous as well as an disadvantageous impact caused by the booming international tourism industry.

It's obvious that the highest authority of the island, which is the government, must ensure that the international tourism industry will continue with its upward trend and at the same time continue to contribute to the island's economy, and to experience a healthy effect upon the life of the individual as well as upon the entire Aruban population.

The government has played an important role in the development of tourism in Aruba, especially during the past 15 years. It has provided the basic infrastructure for the development of the tourist industry, given fiscal incentives for private sector investment in hotel building, provided 
promotion where necessary, established rules for collecting data of visitors and invested in vocational training in the field. However, it is important that future planning for the tourist industry take note not only of its benefits in terms of foreign exchange earnings, generation of income and creation of employment, but also of the cost of these benefits in terms of opportunity costs of the resources expended on tourism and distortions in the economy due to its side-effects (e.g. on land prices, income distribution, etc.) No attempt has been made, so far, to estimate these costs, which may have been substantial. A social costbenefit approach alone would enable the economic planners of the island to measure accurately the contribution of tourism to the economy. Such an exercise appears to Aruba to be a prerequisite for planning the future development of tourism in Aruba.

A dertermination of the net social rate of return from tourism would enable Aruban economic planners to decide the optimum level of investment in the tourist industry in the future, consistent with the overall economic goals of the island.

People continue to travel no matter the economic constraints that are hampering the entire world. The long-term forecasts released by IUOTO some three years ago, made it clear that by 1980 international tourism would reach about 280 million tourists arrival. ${ }^{1}$ Aruba will

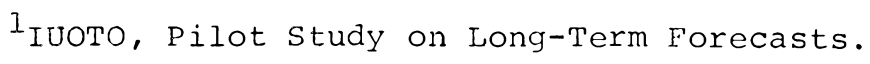


undoubtedly receive part of this estimation and with cooperation of all government departments having an impact on tourism, will produce a balanced tourism growth.

Regarding the above concern, world travel cited:

- . Tourism, we should know by now, is a vulnerable industry, as other industries for that matter, to a greater or lesser degree. Ill-planned or ill-conceived, it can bring a rash of problems in its wake; environmental, political, social or economic. Those countries which have relied too heavily on the tourist dollar crop have come to harm or have had to rue their over-hastiness and lack of planning. Many examples come to mind of those countries that may be suffering from too rapid or excessive tourist development, making it difficult for them to tide over the present depression. Their economies - tourist or otherwise - could be suffering from overheating and we should not fall into the same trap. 2

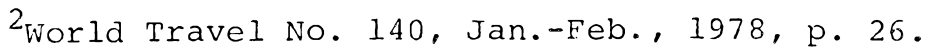


APPENDIX A 
APPENDIX B 


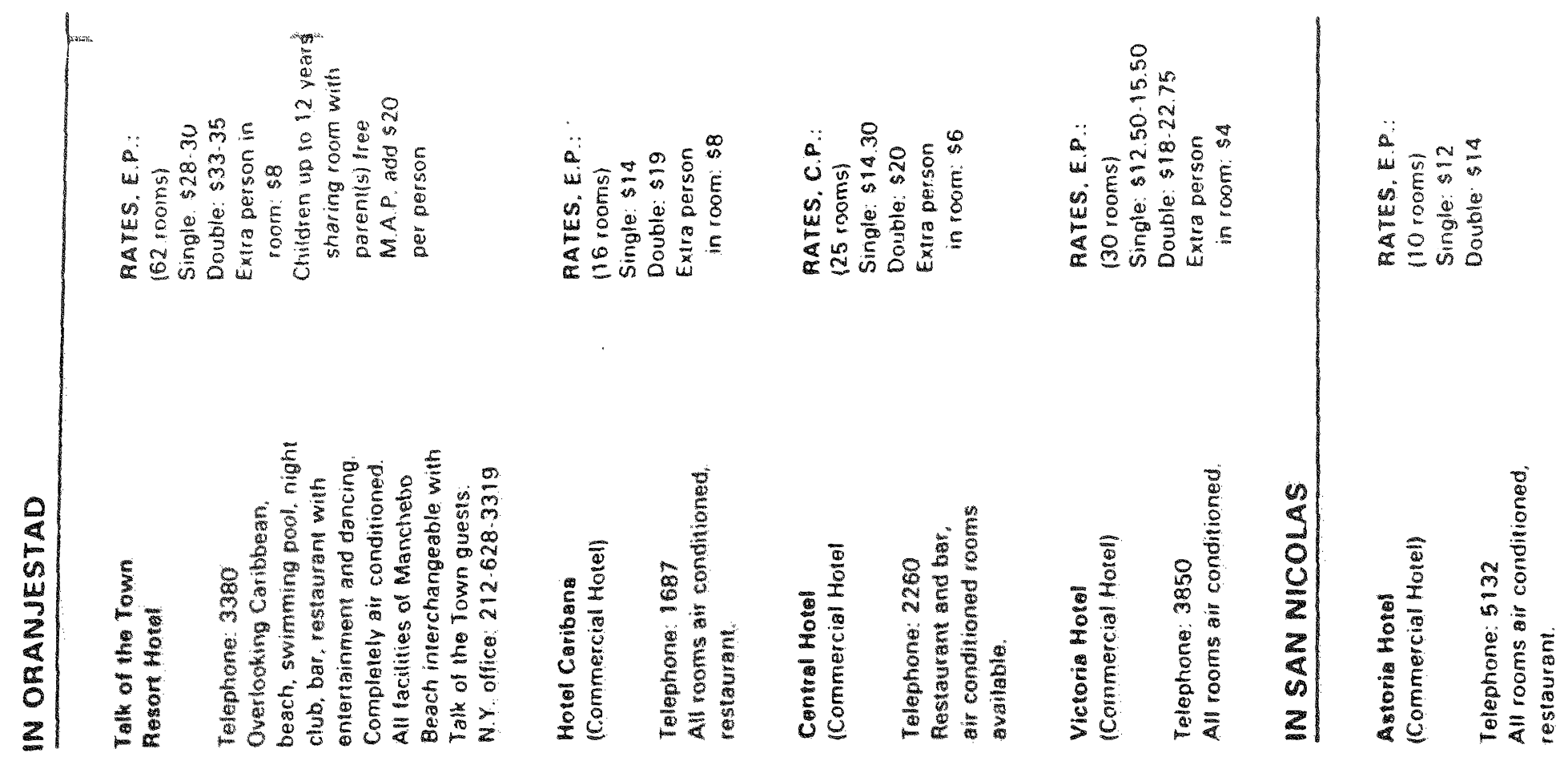

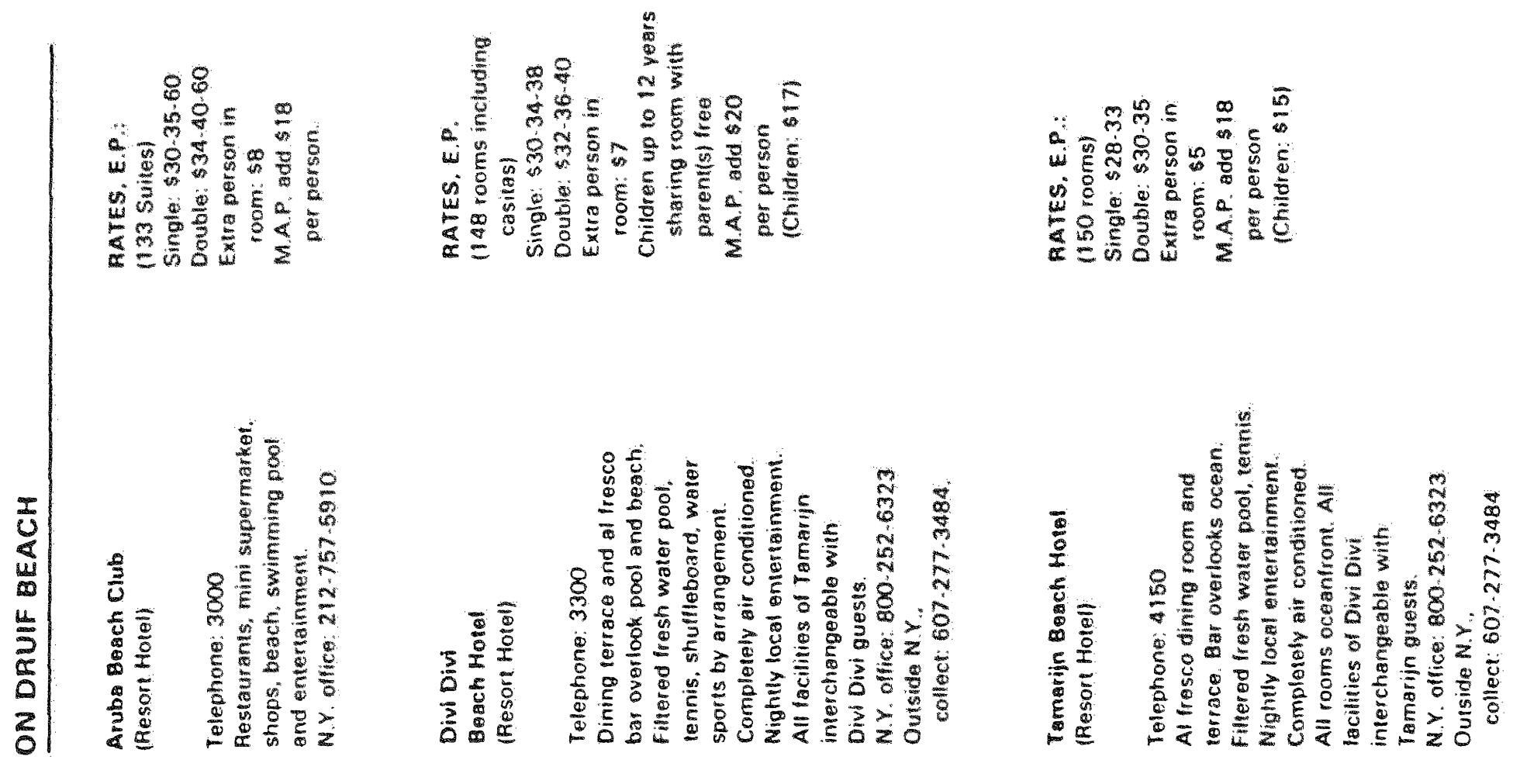

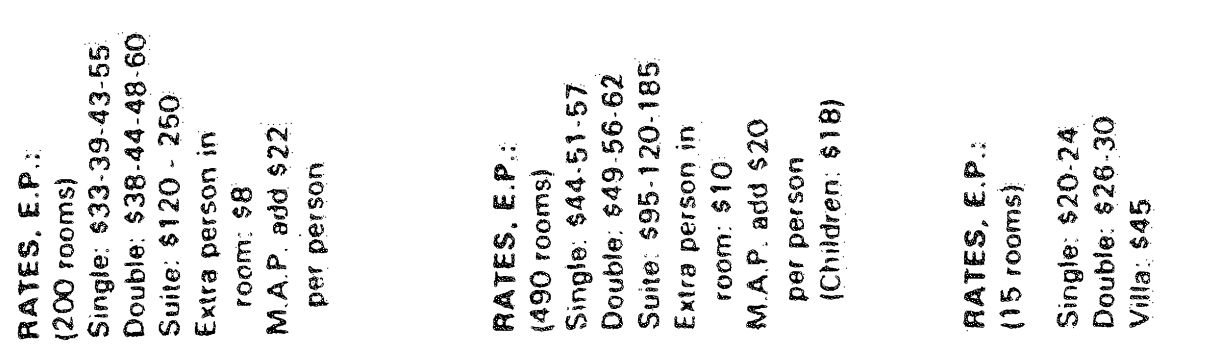

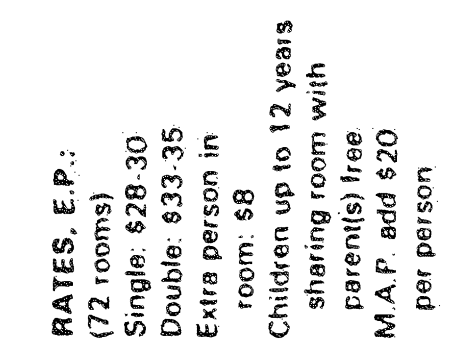

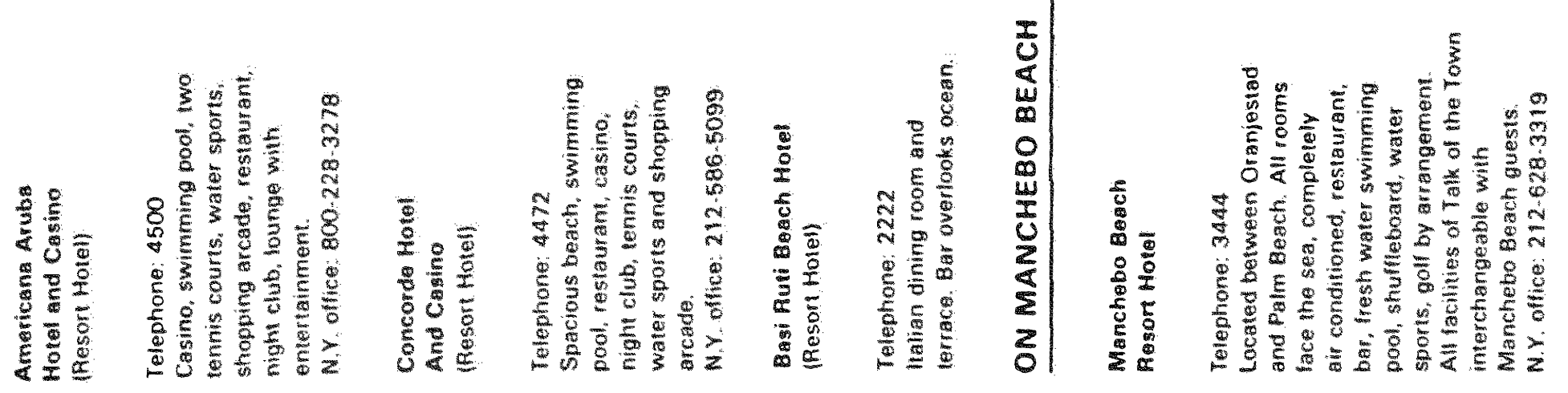

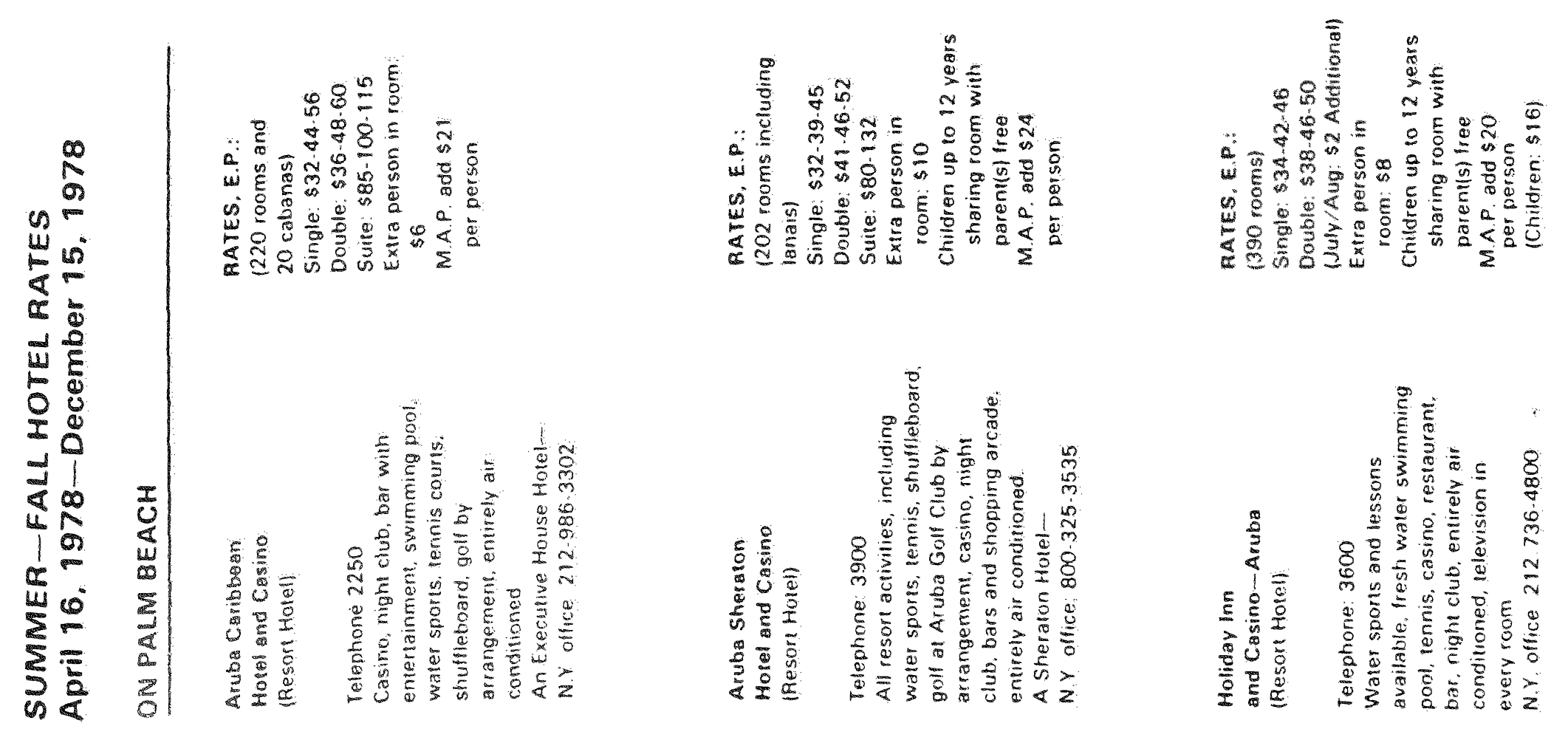




\section{SELECTED BIBLIOGRAPHY}

\section{A. Books}

Bryden, John M. Tourism and Development. Bently House: Syncidates of Cambridge University Press, 1973.

Buckart, A.J. and Medlik, S. Tourist Past, Present and Future. London: Heinemann, 1974.

Gearing, Charles, E., Swart, William w. and Var, Turgut. Planning for Tourism Development Quantitative Approaches. New York: Praeger, 1967.

Hartog, Hohan. Aruba, Past and Present. Aruba: J.D. de Witt, Oranjestad, 1.961 .

Krause, w. and Jud, G. Donald with Joseph, Hyman. International Tourism and Latin American Development. Austin: Bureau of Business Research, University of Texas, 1973.

Mansur, Jossy M., Historia Di Aruba Epoca Spano 1499-1636.

MicIntosh, R.i. Tourism, Principles, Practices, Philosophies. Columbus: Grid, Ind., 1972.

Petty, william. The Economic Writings of Sir William Petty. Cambridge University Press, 1899, 2 Vols.

Rogers, Everett, M. Diffusion of Innovations. New York: Free Press of Glencoe, 1962.

Urguidi, Victor L. The Challenge of Development in Latin America. Translated by Marjory M. Urguidi. New York: Praeger, 1964.

Wahab, Salah, Tourism Management. Tourin, Italy: Tourism International Press, 1975. 
B. Research Reports and Unpublished Papers

Aruba Tourist Bureau. Unpublished Papers. 1977.

Caribbean Tourism Research Centre, Caribbean Tourism, The Economic Impact of Tourism, Barbados, 1975.

Cohen, Erik. Toward a Sociology of International Tourism. Social Research, Spring 1972.

Colorado Visitors Bureau. Annual Summary of Travel. Cited in A.D. Little Inc., Tourism and Recreation, below

Crampon, L.J. A Method of Estimating Tourist Expenditures in Colorado, 1962. Boulder: University of Colorado, Bureau of Business Research, 1963.

Deelrapport I Tourisme of Aruba.

Floriala Development Commission. 1964 Tourist Study. Cited by A.D. Little, Inc., Tourism and Recreation, below.

Goldsmith, William iv. The Impact of the Tourism and Travel Industry on a Developing Regional Economy: The Puerto Rican Case. Cornell University, Ph.D., 1968.

International Union of Official Travel Organization, World Tourism Organization. The Impact on International

Tourism on the Economic Development of the Developing Countries, Geneva: 1975.

Jones, Fremon. Tourism as a Tool for Economic Reference to The Countries of Janaica, Trinidad and Guyana. University of Florida, 1970 .

Kuiperi, M.S. and Estrada R.V., The Reorganization of the Aruban Tourist Bureau, March, 1976.

Little, Arthur D., Inc. Tourism and Recreation, State-ofthe-Art Study, prepared for U.S. Department of Commerce, Economic Development Administration, Office of Regional Economic Development, Nashington, D.C., 1967.

Rapport on The Regional Conference on the Development of a Curriculum in Tourism Education for High and Second... ary Schools in the Caribbean, Dover Convention Centre Barbados, 1978 .

Robinsons, Inc., Marketing Services to the Travel/Hospitality/ Leisure Industries, Aruba Fiotel and Tourism Association Hotel Guest Registrant Analysis December 1, 1977 through May 31; 1978 . 
Rotarians' Travel and Information Guide to Aruba, Aruba Something Special in the Caribbean, 3rd Edition, 1976.

Sethna, R.J. The Social Impact of Tourism. Caribbean Research Centre, 1971.

Statastic Bureau, Department of Economics, Statistics Information, Netherlands Antilles, 1978.

UNESCO, Netherlands Antilles; Education Issues and Prioities for Development, June, 1976.

Unpublished rapport, Department of Economic and Development Affaires, Aruba, 1977.

World Travel, No. 140, January-February, 1978 . 